\title{
Extension of azine-triazole synthesis to azole-triazoles reduces ligand field, leading to spin crossover in tris-L Fe(II)
}

Sandhya Singh and Sally Brooker*

Department of Chemistry and the MacDiarmid Institute for Advanced Materials and Nanotechnology, University of Otago, PO Box 56, Dunedin 9054, New Zealand

\section{Supporting Information}

\section{Contents}

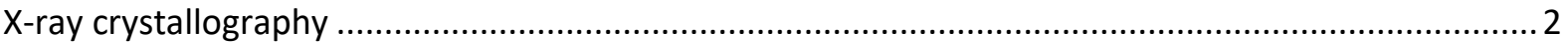

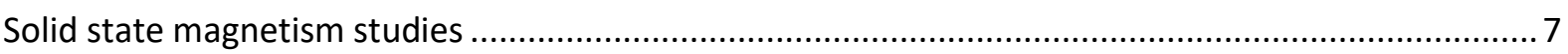

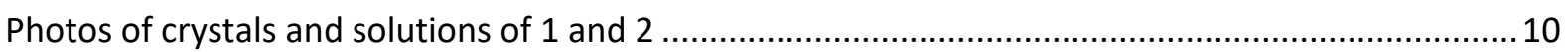

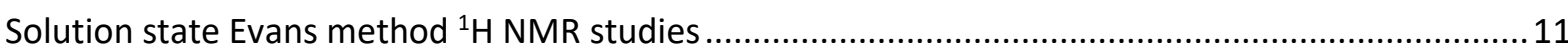

Possible correlations between solution $\mathrm{T}_{1 / 2}$ and different solvent properties ...................................23

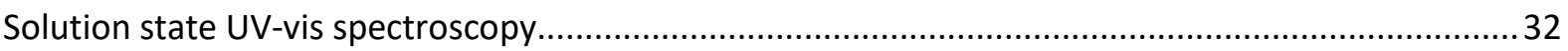

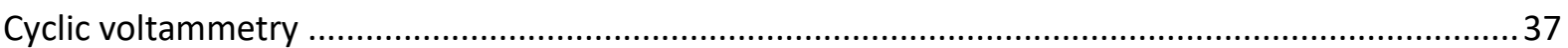

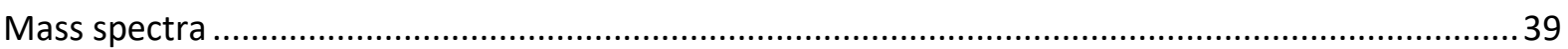

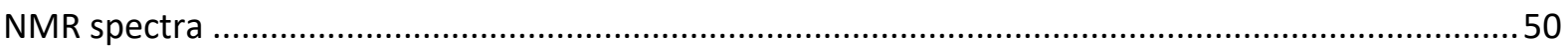

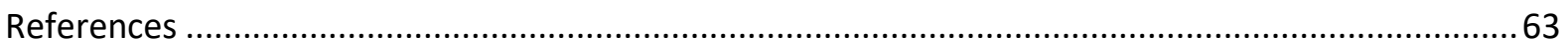




\section{X-ray crystallography}

Table S1. Crystal structure data and refinement parameters for $\mathbf{1}$-solvents and $\mathbf{2}$-solvents.

\begin{tabular}{|c|c|c|}
\hline & 1.solvents (Squeezed) & 2. solvents (Squeezed) \\
\hline $\mathrm{T}[\mathrm{K}]$ & 100 & 100 \\
\hline Empirical formula & $\mathrm{C}_{58} \mathrm{H}_{54} \mathrm{~B}_{2} \mathrm{~F}_{8} \mathrm{FeN}_{16} \mathrm{O}_{2}$ & $\mathrm{C}_{54} \mathrm{H}_{42.25} \mathrm{~B}_{2} \mathrm{~F}_{8} \mathrm{FeN}_{12} \mathrm{O}_{0.13} \mathrm{~S}_{3}$ \\
\hline $\mathrm{Mr}_{\mathrm{r}}$ & 1236.64 & 1186.90 \\
\hline Crystal system & triclinic & triclinic \\
\hline Space group & P-1 & P-1 \\
\hline $\mathrm{a}[\AA]$ & $12.9981(3)$ & $15.8308(4)$ \\
\hline$b[\AA]$ & $16.6933(5)$ & $16.3917(3)$ \\
\hline$c[\AA]$ & $17.0270(6)$ & $24.0574(4)$ \\
\hline$\alpha\left[{ }^{\circ}\right]$ & $86.360(3)$ & $91.455(2)$ \\
\hline$\beta\left[^{\circ}\right]$ & $70.306(3)$ & $104.902(2)$ \\
\hline$\gamma\left[{ }^{\circ}\right]$ & $84.212(2)$ & $110.574(2)$ \\
\hline $\mathrm{V}\left[\AA^{3}\right]$ & $3458.98(19)$ & $5601.6(2)$ \\
\hline Z & 2 & 4 \\
\hline$\rho_{\text {calcd. }}\left[\mathrm{g} / \mathrm{cm}^{3}\right]$ & 1.187 & 1.407 \\
\hline$\mu\left[\mathrm{mm}^{-1}\right]$ & 2.353 & 3.854 \\
\hline$F(000)$ & 1276.0 & 2429.0 \\
\hline Crystal Size (mm) & $0.1 \times 0.08 \times 0.02$ & $0.1 \times 0.1 \times 0.08$ \\
\hline $2 \theta$ range for data collection & 7.25 to 153.674 & 7.246 to 140 \\
\hline Reflections collected & 29970 & 80063 \\
\hline Independent reflections & 14199 & 21221 \\
\hline $\mathrm{R}$ (int) & 0.0522 & 0.0592 \\
\hline Data / restraints / parameters & $14199 / 0 / 819$ & $21221 / 0 / 1495$ \\
\hline Goof $\left(F^{2}\right)$ & 1.063 & 1.041 \\
\hline$R_{l}[I>2 \sigma(I)]$ & 0.0544 & 0.0412 \\
\hline$w_{2}$ [all data] & 0.1517 & 0.1079 \\
\hline Max/min res. e density $\left[\mathrm{e}^{-3}\right]$ & 0.59 and -0.57 & $0.58 /-0.36$ \\
\hline
\end{tabular}


Table S2. Average structural parameters for the tris-ligated Fe(II) mononuclear complexes (1-solvents) and (2·solvents).

\begin{tabular}{|c|c|c|}
\hline & 1.solvents & 2.solvents \\
\hline av. Fe-N (triazole) & 2.197 & $1.976,1.958$ \\
\hline av. Fe-N (azole) & 2.175 & $1.997,1.988$ \\
\hline Distortion angle $\left(\Sigma^{\circ}\right)$ & 92.9 & $58.23,58.20$ \\
\hline Spin state & HS & LS, LS \\
\hline $\begin{array}{l}\text { av. }\left\llcorner\mathrm{N}_{\text {triazole }}-\mathrm{Fe}^{\|}-\mathrm{N}_{\text {azole }}\left({ }^{\circ} \text { ) }\right.\right. \\
\text { (within ligand strand) }\end{array}$ & 75.7 & $80.6,80.6$ \\
\hline $\begin{array}{l}\text { av. Fe-triazole-phenyl ring angle } \\
\left({ }^{\circ}\right)\end{array}$ & 45.9 & $42.9,43.3$ \\
\hline av. triazole-imidazole ring angle & 5.48 & $4.05,7.2$ \\
\hline $\mathrm{T}_{1 / 2}(\mathrm{~K})$ & $\mathrm{HS}$ & 247 \\
\hline
\end{tabular}

Table S3. Bite and torsion angles for the tris-ligated Fe(II) mononuclear complexes (1-solvents) and (2.solvents).

\begin{tabular}{|c|c|l|c|}
\hline $\begin{array}{l}\text { angle within ligand } \\
\mathrm{N}_{\text {triazole }}-\mathrm{Fe} \text { "I-N }\end{array}$ & $\left(^{\circ}\right)$ & Torsion angle & $\left(^{\circ}\right)$ \\
\hline 1.solvents & & & \\
\hline $\mathrm{N} 1-\mathrm{Fe}-\mathrm{N} 4$ & $74.97(7)$ & $\mathrm{N} 1-\mathrm{C} 15-\mathrm{C} 16-\mathrm{N} 4$ & $-2.9(3)$ \\
\hline $\mathrm{N} 6-\mathrm{Fe}-\mathrm{N9}$ & $76.05(8)$ & $\mathrm{N} 6-\mathrm{C} 34-\mathrm{C} 35-\mathrm{N} 9$ & $-0.3(3)$ \\
\hline $\mathrm{N} 11-\mathrm{Fe}-\mathrm{N} 14$ & $75.67(8)$ & $\mathrm{N} 11-\mathrm{C} 53-\mathrm{C} 54-\mathrm{N} 14$ & $-1.7(4)$ \\
\hline 2.solvents & & & \\
\hline $\mathrm{N} 1-\mathrm{Fe} 1-\mathrm{N} 2$ & $80.78(8)$ & $\mathrm{N} 1-\mathrm{C} 3-\mathrm{C} 4-\mathrm{N} 2$ & $1.1(3)$ \\
\hline $\mathrm{N} 5-\mathrm{Fe} 1-\mathrm{N} 6$ & $80.65(8)$ & $\mathrm{N} 5-\mathrm{C} 21-\mathrm{C} 22-\mathrm{N} 6$ & $-3.2(3)$ \\
\hline $\mathrm{N} 9-\mathrm{Fe} 1-\mathrm{N} 10$ & $80.33(8)$ & $\mathrm{N} 9-\mathrm{C} 39-\mathrm{C} 40-\mathrm{N} 10$ & $-1.3(3)$ \\
\hline $\mathrm{N} 13-\mathrm{Fe} 2-\mathrm{N} 14$ & $80.98(8)$ & $\mathrm{N} 13-\mathrm{C} 57-\mathrm{C} 58-\mathrm{N} 14$ & $1.3(3)$ \\
\hline $\mathrm{N} 17-\mathrm{Fe} 2-\mathrm{N} 18$ & $80.29(8)$ & $\mathrm{N} 17-\mathrm{C} 75-\mathrm{C} 76-\mathrm{N} 18$ & $2.9(3)$ \\
\hline $\mathrm{N} 21-\mathrm{Fe} 2-\mathrm{N} 22$ & $80.66(8)$ & $\mathrm{N} 21-\mathrm{C} 93-\mathrm{C} 94-\mathrm{N} 22$ & $9.4(3)$ \\
\hline
\end{tabular}


Table S4. Remaining cis-angles between ligands for the tris-ligated Fe(II) mononuclear complexes (1.solvents) and (2.solvents).

\begin{tabular}{|c|c|c|c|c|c|}
\hline \multicolumn{2}{|c|}{ 1·solvents } & \multicolumn{4}{c|}{ 2·solvents } \\
\hline $\begin{array}{c}\text { angle inbetween } \\
\text { ligand }\end{array}$ & $\left({ }^{\circ}\right)$ & $\begin{array}{c}\text { Fe1 } \\
\text { angle inbetween } \\
\text { ligand }\end{array}$ & $\left(^{\circ}\right)$ & $\begin{array}{c}\text { angle inbetween } \\
\text { ligand }\end{array}$ & $\left({ }^{\circ}\right)$ \\
\hline $\mathrm{N} 1-\mathrm{Fe}-\mathrm{N} 9$ & $91.83(7)$ & $\mathrm{N} 1-\mathrm{Fe}-\mathrm{N} 6$ & $95.90(8)$ & $\mathrm{N} 13-\mathrm{Fe}-\mathrm{N} 17$ & $90.18(8)$ \\
\hline $\mathrm{N} 1-\mathrm{Fe}-\mathrm{N} 11$ & $99.12(7)$ & $\mathrm{N} 1-\mathrm{Fe}-\mathrm{N} 9$ & $93.74(8)$ & $\mathrm{N} 13-\mathrm{Fe}-\mathrm{N} 18$ & $92.75(8)$ \\
\hline $\mathrm{N} 1-\mathrm{Fe}-\mathrm{N} 14$ & $95.64(8)$ & $\mathrm{N} 1-\mathrm{Fe}-\mathrm{N} 10$ & $91.58(8)$ & $\mathrm{N} 13-\mathrm{Fe}-\mathrm{N} 22$ & $95.81(8)$ \\
\hline $\mathrm{N} 4-\mathrm{Fe}-\mathrm{N} 6$ & $94.77(8)$ & $\mathrm{N} 2-\mathrm{Fe}-\mathrm{N} 5$ & $91.23(8)$ & $\mathrm{N} 14-\mathrm{Fe}-\mathrm{N} 17$ & $95.52(8)$ \\
\hline $\mathrm{N} 4-\mathrm{Fe}-\mathrm{N} 9$ & $99.06(8)$ & $\mathrm{N} 2-\mathrm{Fe}-\mathrm{N} 6$ & $91.26(8)$ & $\mathrm{N} 14-\mathrm{Fe}-\mathrm{N} 21$ & $90.94(8)$ \\
\hline $\mathrm{N} 4-\mathrm{Fe}-\mathrm{N} 11$ & $91.51(8)$ & $\mathrm{N} 2-\mathrm{Fe}-\mathrm{N} 10$ & $96.29(8)$ & $\mathrm{N} 14-\mathrm{Fe}-\mathrm{N} 22$ & $94.03(8)$ \\
\hline $\mathrm{N} 6-\mathrm{Fe}-\mathrm{N} 11$ & $94.74(8)$ & $\mathrm{N} 5-\mathrm{Fe}-\mathrm{N} 9$ & $94.44(8)$ & $\mathrm{N} 17-\mathrm{Fe}-\mathrm{N} 21$ & $94.62(8)$ \\
\hline $\mathrm{N} 6-\mathrm{Fe}-\mathrm{N} 14$ & $97.48(8)$ & $\mathrm{N} 5-\mathrm{Fe}-\mathrm{N} 10$ & $92.82(8)$ & $\mathrm{N} 18-\mathrm{Fe}-\mathrm{N} 21$ & $95.58(8)$ \\
\hline $\mathrm{N} 9-\mathrm{Fe}-\mathrm{N} 14$ & $95.44(8)$ & $\mathrm{N} 6-\mathrm{Fe}-\mathrm{N} 9$ & $92.73(8)$ & $\mathrm{N} 18-\mathrm{Fe}-\mathrm{N} 22$ & $90.70(8)$ \\
\hline
\end{tabular}

Table S5. Trans-angles $\mathrm{N}-\mathrm{Fe} \mathrm{II}^{\mathrm{N}} \mathrm{N}$ in the tris-ligated $\mathrm{Fe}(\mathrm{II})$ mononuclear complexes (1-solvents) and (2.solvents).

\begin{tabular}{|c|c|c|c|c|c|}
\hline \multicolumn{2}{|c|}{ 1.solvents } & \multicolumn{4}{c|}{ 2·solvents } \\
\hline Fe & $\left({ }^{\circ}\right)$ & Fe1 & $\left({ }^{\circ}\right)$ & Fe2 & $\left({ }^{\circ}\right)$ \\
\hline Trans angle & & Trans angle & & Trans angle & \\
\hline N1-Fe-N6 & $162.89(8)$ & N1-Fe1-N5 & $171.27(8)$ & N13-Fe2-N21 & $170.98(8)$ \\
\hline N4-Fe-N14 & $162.91(8)$ & N2-Fe1-N9 & $173.53(8)$ & N14-Fe2-N18 & $172.50(9)$ \\
\hline N9-Fe-N11 & $166.45(8)$ & N6-Fe1-N10 & $170.14(8)$ & N17-Fe2-N22 & $169.42(8)$ \\
\hline
\end{tabular}

Table S6. Triazole-imidazole plane angle and Fe triazole-phenyl plane angle in the tris-ligated Fe(II) mononuclear complexes (1·solvents) and (2·solvents).

\begin{tabular}{|c|c|c|c|}
\hline \multicolumn{4}{|c|}{ 1.solvents } \\
\hline triazole-imidazole angle & $\left({ }^{\circ}\right)$ & Fe triazole-phenyl ring angle & $\left({ }^{\circ}\right)$ \\
\hline L N1 C15 N3 C7 N2- N4 C16 C17 N5 C19 & 11.58 & $\begin{array}{l}\text { LFe1 N1 C15 N3 C7 N2-C6 } \\
\text { C1 C2 C3 C4 C5 }\end{array}$ & 48.93 \\
\hline LN6 C34 N8 C26 N7- N9 C35 C36 N10 C38 & 1.58 & $\begin{array}{l}\text { LFe1 N6 C34 N8 C26 N7-C25 } \\
\text { C24 C23 C22 C21 C20 }\end{array}$ & 50.87 \\
\hline $\begin{array}{c}\text { L N11 C53 N13 C45 N12- N14 C54 C55 } \\
\text { N101 C56 }\end{array}$ & 3.30 & $\begin{array}{l}\text { LFe1 N11 C53 N13 C45 N12- } \\
\text { C44 C39 C40 C41 C42 C43 }\end{array}$ & 37.86 \\
\hline \multicolumn{4}{|c|}{ 2. solvents } \\
\hline triazole-imidazole angle & $\left({ }^{\circ}\right)$ & Fe triazole-phenyl ring angle & $\left({ }^{\circ}\right)$ \\
\hline LN2 C4 N4 C12 N3- N1 C1 S1 C2 C3 & 3.80 & $\begin{array}{l}\text { Fe1 N2 C4 N4 C12 N3- C13 } \\
\text { C18 C17 C16 C15 C14 }\end{array}$ & 46.06 \\
\hline LN6 C22 N8 C30 N7- N5 C19 S2 C20 C21 & 5.53 & $\begin{array}{l}\text { Fe1 N6 C22 N8 C30 N7- C31 } \\
\text { C32 C33 C34 C35 C36 }\end{array}$ & 44.48 \\
\hline $\begin{array}{c}\text { LN10 C40 N12 C48 N11- N9 C37 S3 C38 } \\
\text { C39 }\end{array}$ & 2.84 & $\begin{array}{l}\text { Fe1 N10 C40 N12 C48 N11- } \\
\text { C49 C54 C53 C52 C51 C50 }\end{array}$ & 38.14 \\
\hline $\begin{array}{c}\text { N14 C58 N16 C66 N15- N13 C55 S4 C56 } \\
\text { C57 }\end{array}$ & 3.62 & $\begin{array}{l}\text { Fe2 N14 C58 N16 C66 N15- } \\
\text { C67 C68 C69 C70 C71 C72 }\end{array}$ & 41.66 \\
\hline $\begin{array}{c}\text { N18 C76 N20 C84 N19- N17 C73 S5 C74 } \\
\text { C75 }\end{array}$ & 5.32 & $\begin{array}{l}\text { Fe2 N18 C76 N20 C84 N19- } \\
\text { C85 C86 C87 C88 C89 C90 }\end{array}$ & 58.87 \\
\hline $\begin{array}{c}\text { N22 C94 N24 C102 N23- N21 C91 S6 C92 } \\
\text { C93 }\end{array}$ & 12.66 & $\begin{array}{l}\text { Fe2 N22 C94 N24 C102 N23- } \\
\text { C103 C104 C105 C106 C107 } \\
\text { C108 }\end{array}$ & 29.48 \\
\hline
\end{tabular}


Table S7. The hydrogen bonds observed in 2. solvents with partial occupancy $\mathrm{H}_{2} \mathrm{O}$ molecule

\begin{tabular}{|l|l|l|l|}
\hline $\mathrm{D}-\mathrm{H} \cdots \mathrm{A}$ & $\mathrm{D}-\mathrm{A}(\AA)$ & $\mathrm{H} \cdots \mathrm{A}(\AA)$ & $\mathrm{D}-\mathrm{H} \cdots \mathrm{A}\left({ }^{\circ}\right)$ \\
\hline $\mathrm{C} 27-\mathrm{H} 27 \mathrm{~B} \cdots \mathrm{O} 101$ & $2.907(.014)$ & $1.986(.012)$ & $155.68(0.45)$ \\
\hline $\mathrm{C} 11-\mathrm{H} 11 \cdots \mathrm{O} 101$ & $3.284(.013)$ & $2.428(.013)$ & $149.76(0.31)$ \\
\hline $\mathrm{C} 53-\mathrm{H} 53 \cdots \mathrm{O} 101$ & $3.251(.010)$ & $2.376(.011)$ & $152.89(0.33)$ \\
\hline $\mathrm{O} 101-\mathrm{H} 10 \mathrm{~B} \cdots \mathrm{N} 3$ & $3.153(.010)$ & $2.487(.002)$ & $135.84(0.69)$ \\
\hline $\mathrm{O} 101-\mathrm{H} 10 \mathrm{~A} \cdots \mathrm{N} 11$ & $2.852(.010)$ & $2.049(.002)$ & $157.31(0.66)$ \\
\hline
\end{tabular}

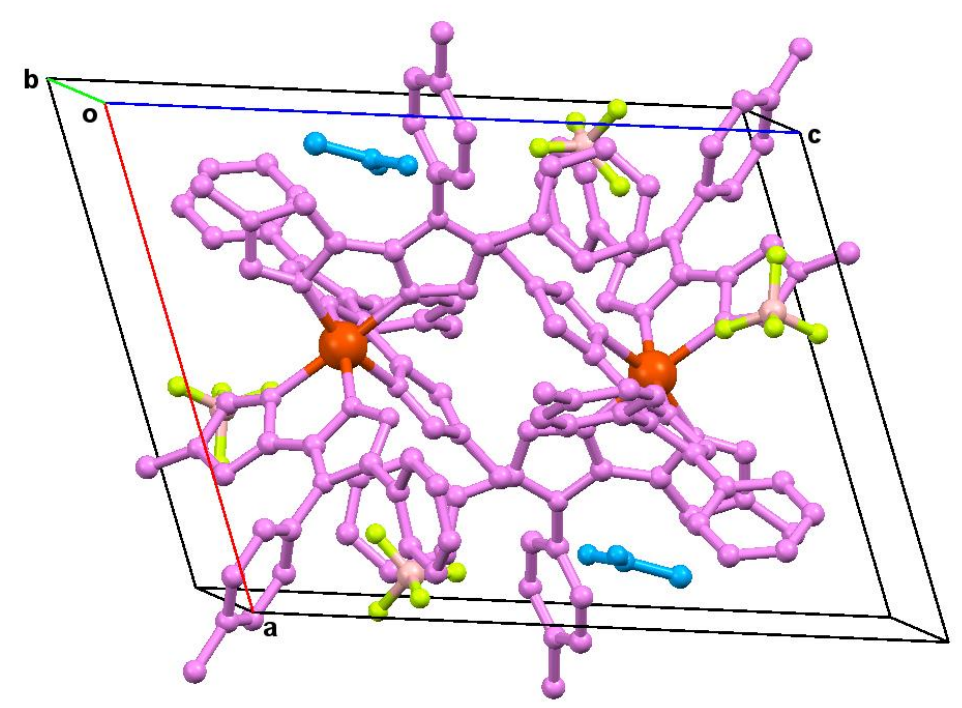

Figure S1. Unit cell crystal packing of $\left[\mathrm{Fe}\left(\mathrm{L}^{\mathrm{ANMelm}}\right)_{3}\right]\left(\mathrm{BF}_{4}\right)_{2} \cdot \mathrm{CH}_{3} \mathrm{NO}_{2} \cdot$ solvent (1. solvents), two mononuclear cationic units shown in violet, two nitromethane shown in blue and four counteranions. Hydrogen atoms are not shown. 


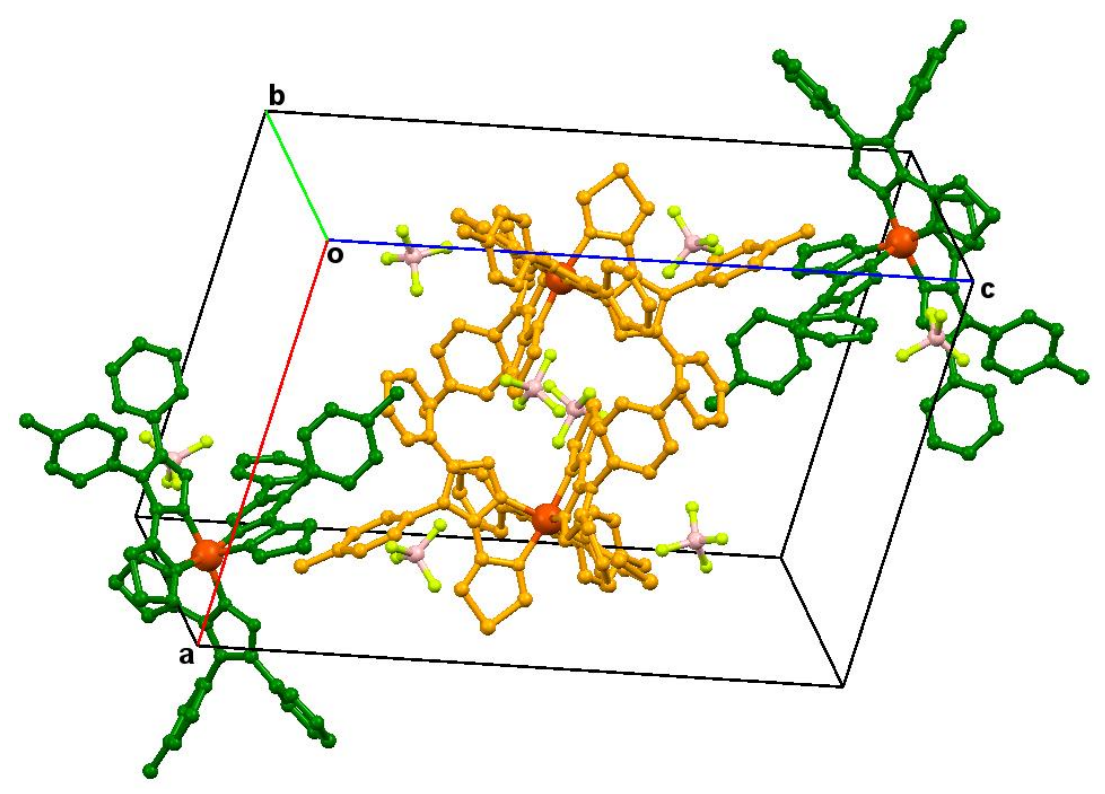

Figure S2. Unit Cell crystal packing of $\left[\mathrm{Fe}\left(\mathrm{L}^{4 S \mathrm{Im}}\right)_{3}\right]\left(\mathrm{BF}_{4}\right)_{2} \cdot 0.125 \mathrm{H}_{2} \mathrm{O} \cdot$ solvent (2.solvents), four mononuclear cationic units shown in green and orange (two crystallographically unique cationic unit shown in green and orange), eight $\mathrm{BF}_{4}$ counteranions. Hydrogen atoms are not shown. 
Solid state magnetism studies

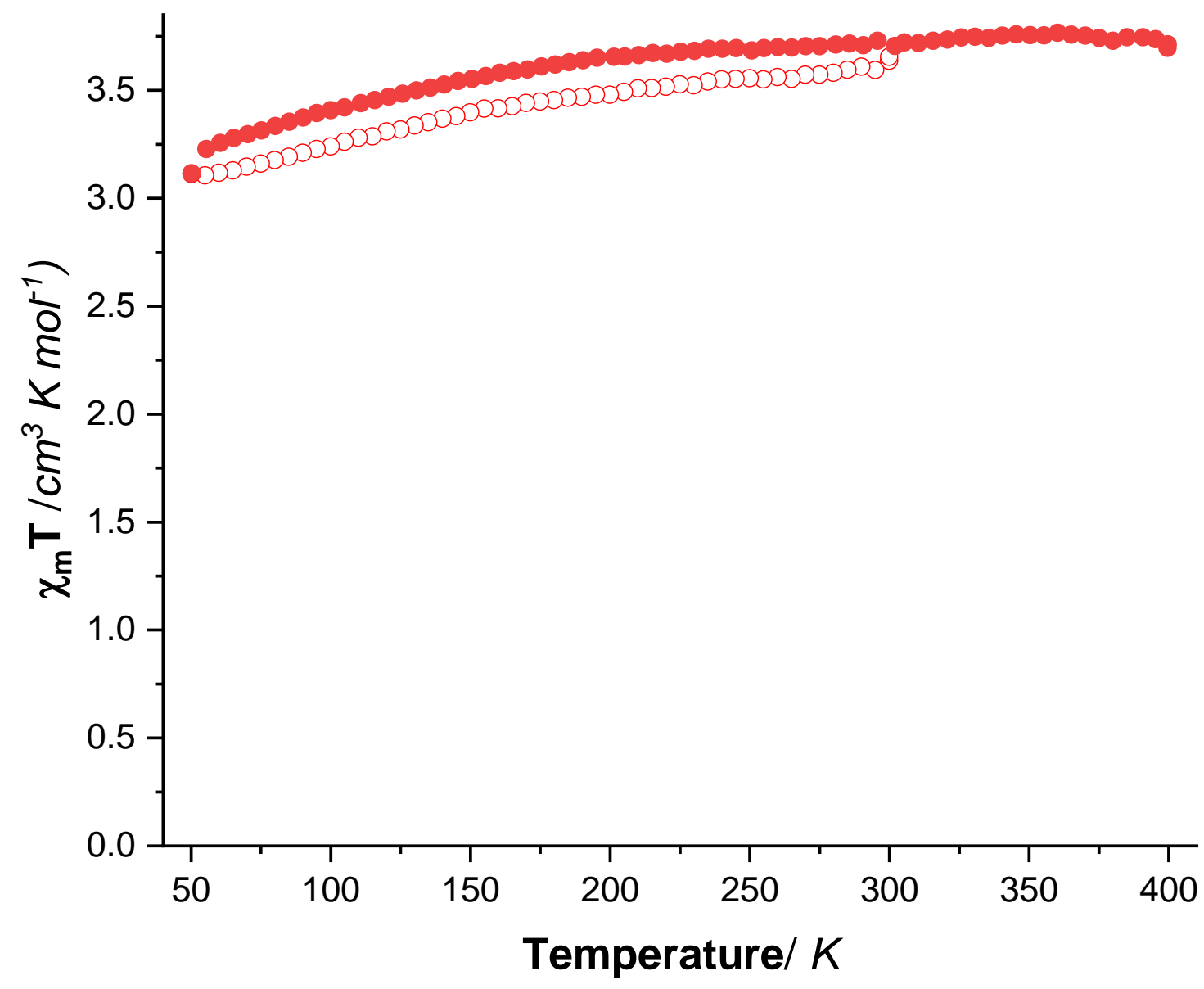

Figure S3. $\chi_{M} T$ versus $T$ plot for a solid sample of $\left[\mathrm{Fe}^{\prime \prime}\left(\mathrm{L}^{4 \mathrm{NMelm}}\right)_{3}\right]\left(\mathrm{BF}_{4}\right)_{2} \cdot 4 \mathrm{H}_{2} \mathrm{O}\left(\mathbf{1} \cdot 4 \mathrm{H}_{2} \mathrm{O}\right)$ cooling 300 to 50 $\mathrm{K}$ (open circles) then heating 50 to $400 \mathrm{~K}$ (filled circles), in sweep mode at $5 \mathrm{~K} \mathrm{~min}^{-1}$. 


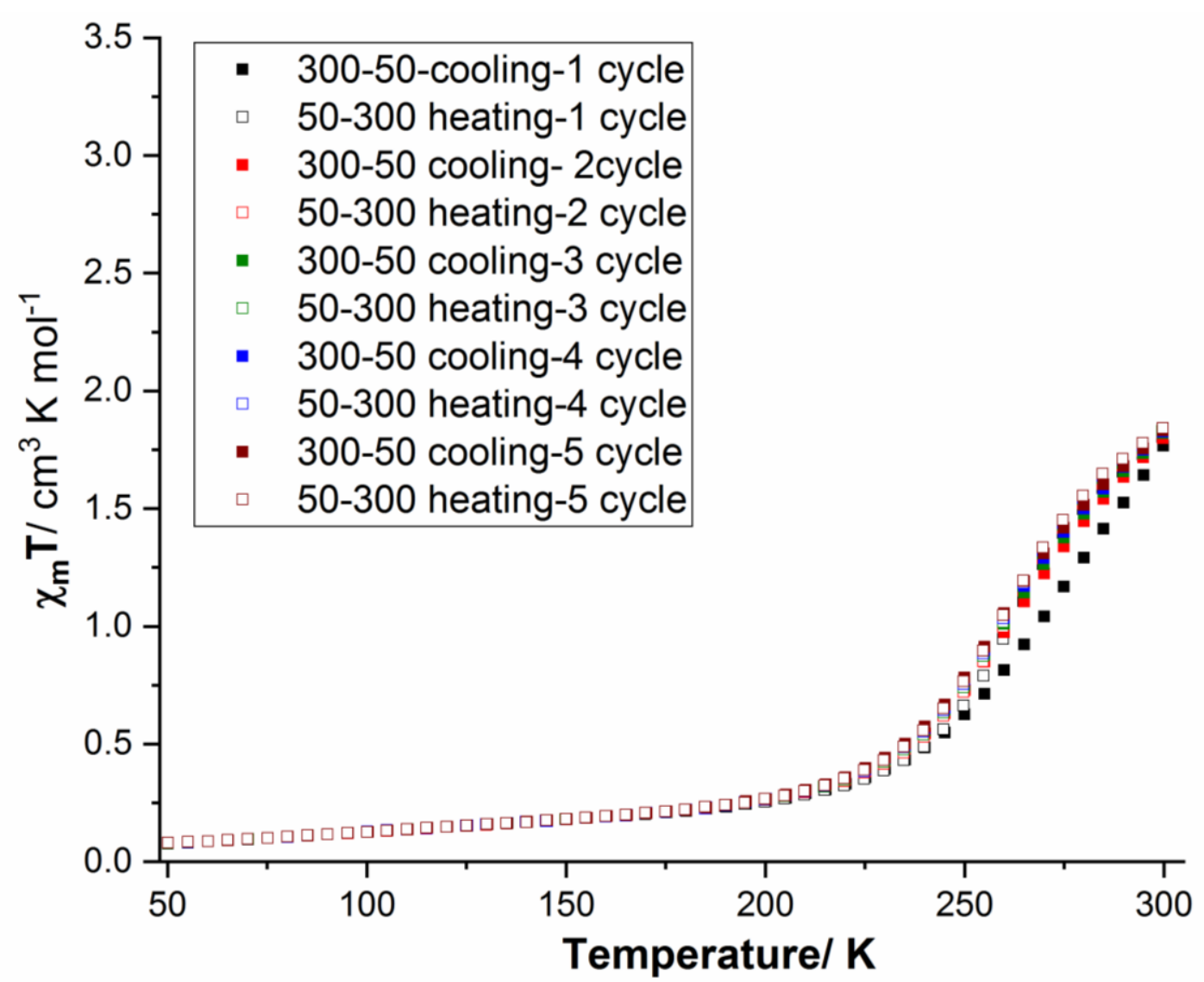

Figure S4. $\chi_{M} T$ versus $T$ plot for a solid sample of $\left[\mathrm{Fe}^{\prime \prime}\left(\mathrm{L}^{4 \mathrm{SIm}}\right)_{3}\right]\left(\mathrm{BF}_{4}\right)_{2} \cdot 0.5 \mathrm{H}_{2} \mathrm{O} \quad\left(\mathbf{2} \cdot 0.5 \mathrm{H}_{2} \mathrm{O}\right)$ cooling (filled squares) then heating (open squares), carried out for 5 cycles, in $5 \mathrm{~K}$ steps, changing temperatures at $5 \mathrm{~K} \mathrm{~min}^{-1}$, in settle mode (see experimental section in paper for details). Microanalysis was carried out on the sample immediately before and after this magnetic data collection (see table below); this is consistent with no loss of water at $300 \mathrm{~K}$ - but is not conclusive. See the next Figure and Table for data collected on cycling to higher temperatures (400 K).

\begin{tabular}{|l|l|l|l|}
\hline Sample & C\% & H\% & N\% \\
\hline Calcd. for 2.0.5(H2O) & 54.34 & 3.63 & 14.08 \\
\hline $\begin{array}{l}\text { Found for SS482 before magnetism } \\
\text { cycles to 300 K }\left(\Delta \text { to 2.0.5 }\left(\mathrm{H}_{2} \mathrm{O}\right)\right)\end{array}$ & $54.24(0.10)$ & $3.74(-0.11)$ & $14.14(-0.06)$ \\
\hline $\begin{array}{l}\text { Found for SS482 after magnetism } \\
\text { cycles to } 300 \mathrm{~K}\left(\Delta \text { to 2.0.5 }\left(\mathrm{H}_{2} \mathrm{O}\right)\right)\end{array}$ & $54.22(0.12)$ & $3.78(-0.15)$ & $14.34(-0.26)$ \\
\hline Calcd. for 2 & 54.75 & 3.75 & 14.19 \\
\hline $\begin{array}{l}\text { Found for SS482 after magnetism } \\
\text { cycles to 300 K }(\Delta \text { to } 2)\end{array}$ & $54.22(\mathbf{0 . 5 3})$ & $3.78(-0.03)$ & $14.34(-0.15)$ \\
\hline
\end{tabular}




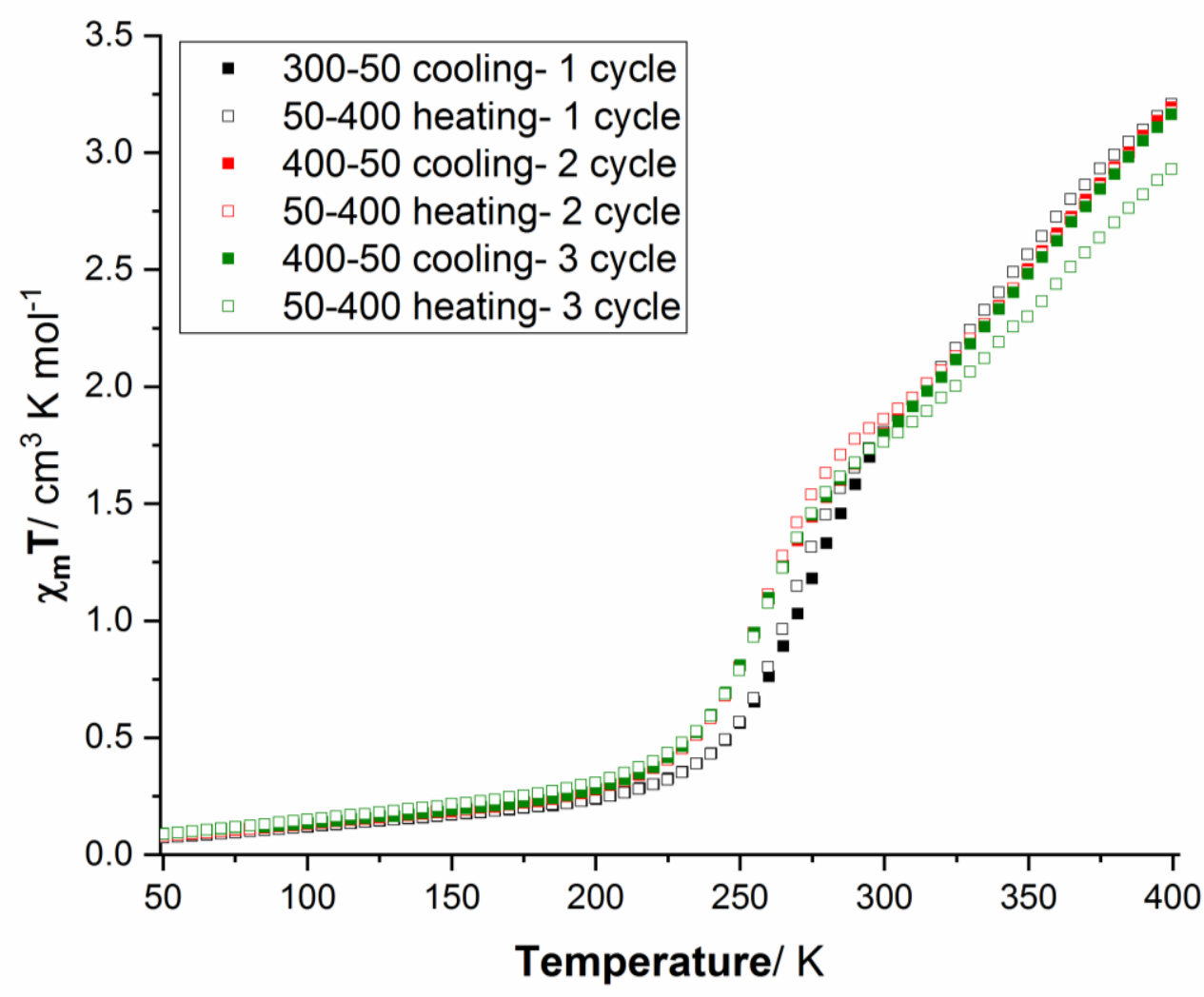

Figure S5. For completeness, a copy of Figure 4 is also provided here: $\chi_{M} T$ versus $T$ plot for $\left[\mathrm{Fe}^{\prime \prime}\left(\mathrm{L}^{4 \mathrm{SIm}}\right)_{3}\right]\left(\mathrm{BF}_{4}\right)_{2} \cdot 0.5 \mathrm{H}_{2} \mathrm{O} \quad\left(2 \cdot 0.5 \mathrm{H}_{2} \mathrm{O}\right)$ over three successive cycles, 300-50-400, 400-50-400 $\mathrm{K}$ and $400-$ $50-400 \mathrm{~K}$ (cooling = filled squares; heating = open squares), in settle mode (see experimental section in paper for details). Microanalysis was carried out on the sample immediately before and after this magnetic data collection (see table below); this is consistent with loss of water at $400 \mathrm{~K}$ - but is not conclusive. See the previous Figure and Table for data collected on cycling to lower temperatures (300 K).

\begin{tabular}{|c|c|c|c|}
\hline Sample & $\mathrm{C} \%$ & $\mathrm{H} \%$ & N\% \\
\hline Calcd. for $2 \cdot 0.5(\mathrm{H} 2 \mathrm{O})$ & 54.34 & 3.63 & 14.08 \\
\hline $\begin{array}{l}\text { Found for SS482 before magnetism } \\
\text { cycles to } 400 \mathrm{~K}\left(\Delta \text { to } 2 \cdot 0.5\left(\mathrm{H}_{2} \mathrm{O}\right)\right)\end{array}$ & $54.15(0.19)$ & $3.74(-0.11)$ & $14.14(-0.06)$ \\
\hline $\begin{array}{l}\text { Found for SS482 after magnetism } \\
\text { cycles to } 400 \mathrm{~K}\left(\Delta \text { to } 2 \cdot 0.5\left(\mathrm{H}_{2} \mathrm{O}\right) \text { ) }\right.\end{array}$ & $54.69(-0.35)$ & $3.64(-0.01)$ & $14.07(0.01)$ \\
\hline $\begin{array}{l}\text { Found for SS482 after magnetism } \\
\text { cycles to } 400 \mathrm{~K}(\Delta \text { to } 2)\end{array}$ & $54.69(0.06)$ & $3.64(-0.07)$ & $14.07(0.12)$ \\
\hline Calcd. for $\mathbf{2}$ & 54.75 & 3.75 & 14.19 \\
\hline
\end{tabular}




\section{Photos of crystals and solutions of 1 and 2}
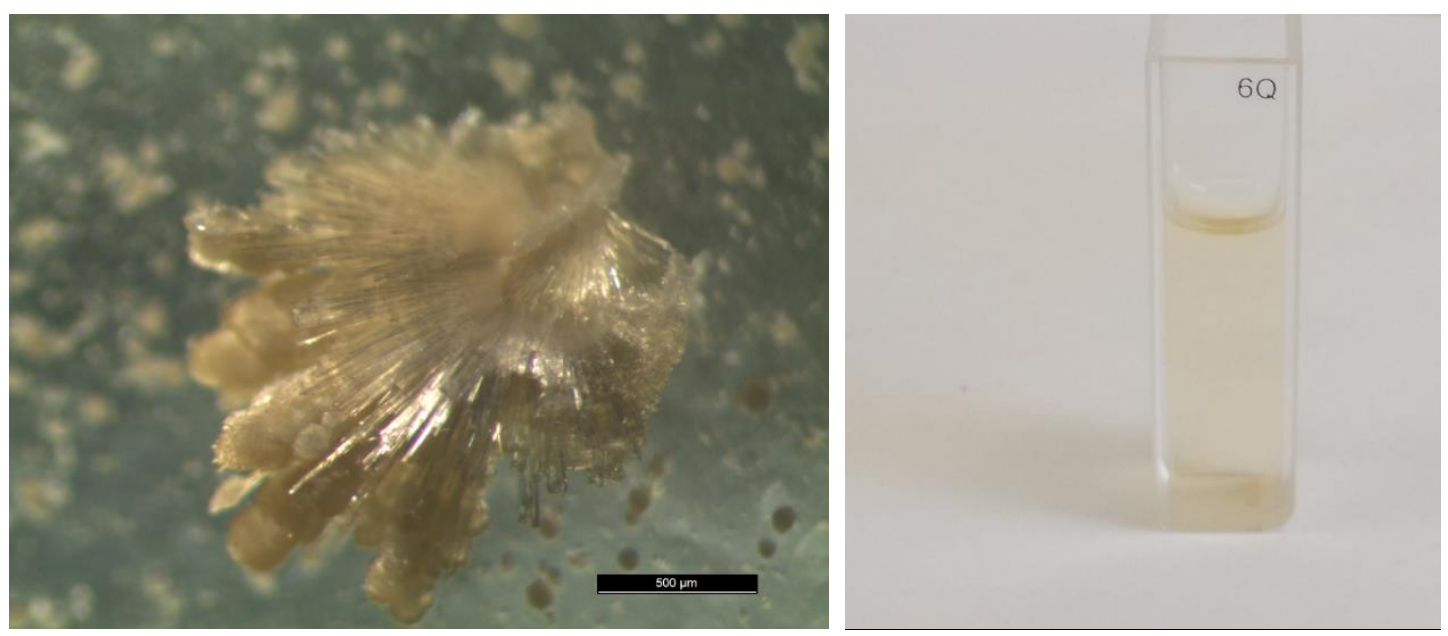

Figure S6. Needle shaped off-white $\left[\mathrm{Fe}\left(\mathrm{L}^{4 \mathrm{NMelm}}\right)_{3}\right]\left(\mathrm{BF}_{4}\right)_{2}\left(\mathbf{1} \cdot 4 \mathrm{H}_{2} \mathrm{O}\right)$ after air-drying (image taken under optical microscope, left) and acetonitrile solution of $1.4 \mathrm{H}_{2} \mathrm{O}(7.1 \mathrm{mM})$ used in UV-vis studies (right).
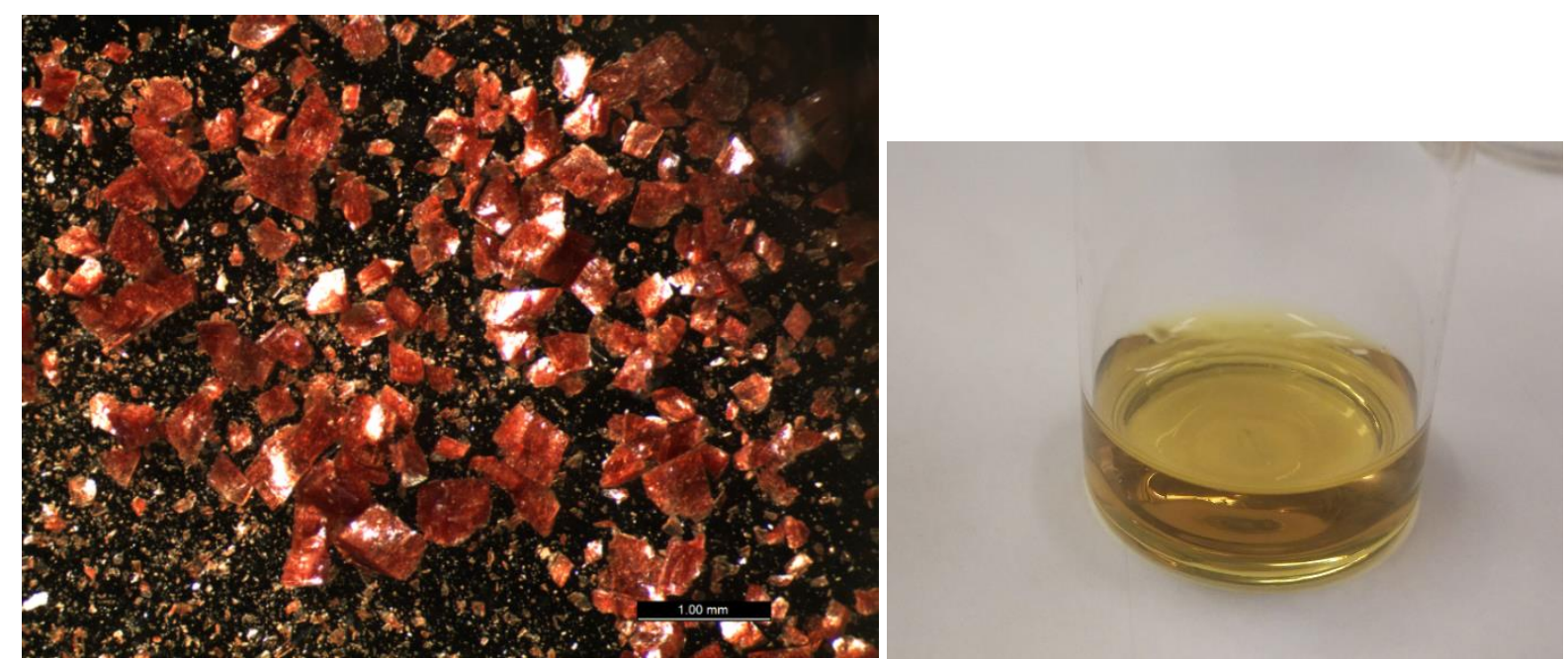

Figure S7. Block shaped orange $\left[\mathrm{Fe}\left(\mathrm{L}^{4 \mathrm{SIm}}\right)_{3}\right]\left(\mathrm{BF}_{4}\right)_{2}\left(2 \cdot 0.5 \mathrm{H}_{2} \mathrm{O}\right)$ after air-drying (image taken under optical microscope, left) and acetonitrile solution of $2 \cdot 0.5 \mathrm{H}_{2} \mathrm{O}(4.8 \mathrm{mM})$ used in UV-vis studies (right). 


\section{Solution state Evans method ${ }^{1} \mathrm{H}$ NMR studies}

For the solution state Evans method VT-NMR spectra, a $5 \mathrm{mM}$ solution of $\mathbf{1} \cdot 4 \mathrm{H}_{2} \mathrm{O}$ was used and 10.6 $\mathrm{mM}$ solutions of $\mathbf{2} \cdot 0.5 \mathrm{H}_{2} \mathrm{O}$ in five different solvents, $\mathrm{CD}_{3} \mathrm{NO}_{2}, \mathrm{CD}_{3} \mathrm{CN}, \mathrm{C}_{2} \mathrm{D}_{6} \mathrm{CO}, \mathrm{CDCl}_{3}$ and $\mathrm{CD}_{2} \mathrm{Cl}_{2}$ were used. Only $2 \cdot 0.5 \mathrm{H}_{2} \mathrm{O}$ was SCO-active, so those data were modelled with the regular solution model Equation S1 (below). The $\mathrm{R}^{2}$ for all fits was 0.99 (for all solvents studied; see Table S8, Figures S9-S13 below). The range of $\Delta H\left(12-21 \mathrm{~kJ} \cdot \mathrm{mol}^{-1}\right)$ and $\Delta S\left(48-88 \mathrm{~J} \cdot \mathrm{mol}^{-1} \cdot \mathrm{K}^{-1}\right)$ values obtained from the fit (Table S8) fall in the expected literature ranges for solution studies of SCO-active iron(II) complexes $(\Delta H=4$ $41 \mathrm{~kJ} \cdot \mathrm{mol}^{-1}$ and $\left.\Delta S=22-146 \mathrm{~J} \cdot \mathrm{mol}^{-1} \cdot \mathrm{K}^{-1}\right) \cdot{ }^{1-3}$ The modelling to equation $\mathrm{S} 1$ was carried out in OriginPro 2018 from OriginLab Corporation; Excel was also employed, to determine 95\% confidence intervals and help assign appropriate errors to the parameters obtained from the fit (Figures S9-S13). Note that the expected error in temperature in an VT-NMR instrument is $\pm 1 \mathrm{~K}$, and error associated with the Evan's method determination of $\chi_{\mathrm{m}} \mathrm{T}(\mathrm{T})$ is $5 \%$, so significant errors are expected in the derived parameters ${ }^{1}$ (Table S8).

$$
\chi_{m} T(T)=\frac{\chi_{m} T(\max )}{1+e^{\left(\frac{\Delta H}{R T}-\frac{\Delta S}{R}\right)}} \quad \text { (Equation S1) }
$$

Where:

$\chi_{m} T(T)$ is the molar magnetic susceptibility at temperature $T$.

$\chi_{m} \mathrm{~T}(\max )$ was, in all fits, set to $3.7 \mathrm{~cm}^{3} \mathrm{~mol}^{-1} \mathrm{~K}^{4}$

$\mathrm{R}$ is the ideal gas constant $\left(8.314472 \mathrm{~J} \mathrm{~mol}^{-1} \mathrm{~K}^{-1}\right)$.

The parameters obtained from the fit include:

$\Delta \mathrm{H}$ and $\Delta \mathrm{S}$, the thermodynamic enthalpy and entropy values associated with the SCO event.

$\mathrm{T}_{1 / 2}$, the SCO transition temperature $=\Delta H / \Delta S$.

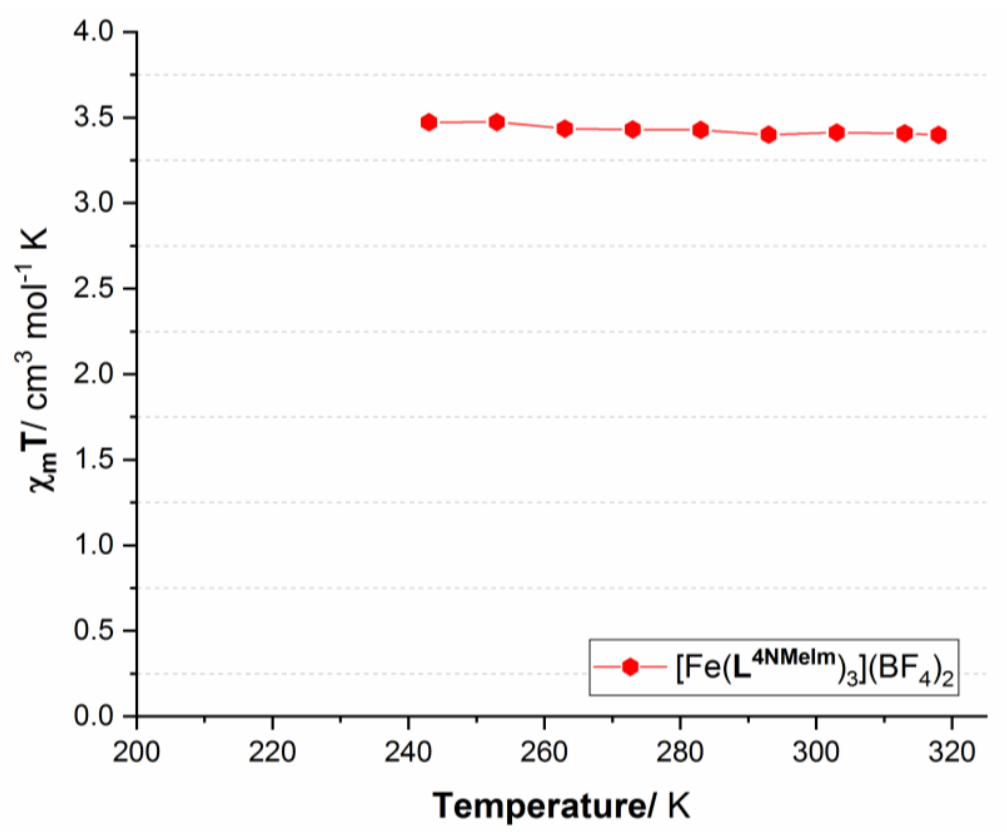

Figure S8. $\chi_{\mathrm{m}} \mathrm{T}$ vs $\mathrm{T}$ for $5 \mathrm{mM}$ of $\left[\mathrm{Fe}\left(\mathrm{L}^{4 \mathrm{NMelm}}\right)_{3}\right]\left(\mathrm{BF}_{4}\right)_{2}\left(\mathbf{1} \cdot 4 \mathrm{H}_{2} \mathrm{O}\right)$ in $\mathrm{CD}_{3} \mathrm{CN}$ solution state Evans method studies $(500 \mathrm{MHz})$. 
Table S8. The thermodynamic parameters $\Delta \mathrm{H}, \Delta \mathrm{S}$ and $\mathrm{T}_{1 / 2}$ values obtained for $\mathbf{2} \cdot 0.5 \mathrm{H}_{2} \mathrm{O}$, by modelling the VT-NMR data with the regular solution model (Equation S1, details above). Indicated errors are estimated from both the (Origin) fit itself , and the (Excel) $95 \%$ confidence intervals analysis (Figures S9-S19).

\begin{tabular}{|c|c|c|c|c|}
\hline & $\mathbf{T}_{1 / 2}(\mathrm{~K})$ & $\boldsymbol{\Delta} \boldsymbol{H}\left(\mathrm{kJ} \cdot \mathrm{mol}^{-1}\right)$ & $\boldsymbol{\Delta} \boldsymbol{S}\left(\mathrm{J} \cdot \mathrm{mol}^{-1} \cdot \mathrm{K}^{-1}\right)$ & $\mathbf{R}^{\mathbf{2}}$ \\
\hline $\mathrm{CD}_{3} \mathrm{NO}_{2}$ & $243 \pm 1$ & $11.6 \pm 0.4$ & $48 \pm 2$ & 0.99 \\
\hline $\mathrm{CD}_{3} \mathrm{CN}$ & $249 \pm 1$ & $15.4 \pm 0.4$ & $62 \pm 2$ & 0.99 \\
\hline $\mathrm{C}_{2} \mathrm{D}_{6} \mathrm{CO}$ & $259 \pm 1$ & $15.7 \pm 0.4$ & $61 \pm 2$ & 0.99 \\
\hline $\mathrm{CDCl}_{3}$ & $214 \pm 1$ & $13.6 \pm 0.4$ & $64 \pm 2$ & 0.99 \\
\hline $\mathrm{CD}_{2} \mathrm{Cl}_{2}$ & $234 \pm 1$ & $20.7 \pm 0.4$ & $88 \pm 2$ & 0.99 \\
\hline
\end{tabular}

Table S9. T (K) and $\chi_{\mathrm{m}} \mathbf{T}\left(\mathrm{cm}^{3} \mathrm{~K} \mathrm{~mol}^{-1}\right)$ calculated from Evans method NMR data (500 MHz) for $10.6 \mathrm{mM}$ solutions of $\left[\mathrm{Fe}\left(\mathrm{L}^{4 \mathrm{SIm}}\right)_{3}\right]\left(\mathrm{BF}_{4}\right)_{2}\left(2 \cdot 0.5 \mathrm{H}_{2} \mathrm{O}\right)$ in five different solvents: $\mathrm{CD}_{3} \mathrm{NO}_{2}, \mathrm{CD}_{3} \mathrm{CN}, \mathrm{C}_{2} \mathrm{D}_{6} \mathrm{CO}, \mathrm{CDCl}_{3}$ and $\mathrm{CD}_{2} \mathrm{Cl}_{2}$.

\begin{tabular}{|c|c|c|c|}
\hline \multirow{2}{*}{$\mathrm{T} / \mathrm{K}$} & \multicolumn{3}{|c|}{$\chi_{\mathrm{m}} \mathbf{T}\left(\mathrm{cm}^{3} \mathrm{~K} \mathrm{~mol}^{-1}\right)$} \\
\cline { 2 - 4 } & $\mathrm{CD}_{3} \mathbf{N O}_{2}$ & $\mathbf{C D}_{3} \mathbf{C N}$ & $\mathbf{C}_{2} \mathbf{D}_{6} \mathbf{C O}$ \\
\hline 243 & - & 1.6558 & 1.39579 \\
\hline 253 & 2.054 & 1.95946 & 1.68902 \\
\hline 263 & 2.239 & 2.2427 & 1.96152 \\
\hline 273 & 2.435 & 2.46369 & 2.20714 \\
\hline 283 & 2.565 & 2.66076 & 2.43206 \\
\hline 293 & 2.698 & 2.80264 & 2.6046 \\
\hline 303 & 2.780 & 2.92157 & 2.74358 \\
\hline 313 & 2.860 & 3.02826 & 2.83869 \\
\hline 323 & 2.955 & 3.10118 & - \\
\hline 333 & 3.067 & 3.19719 & - \\
\hline 343 & 3.180 & 3.27175 & - \\
\hline
\end{tabular}

\begin{tabular}{|c|c|c|}
\hline \multirow{2}{*}{$\mathrm{T} / \mathrm{K}$} & \multicolumn{2}{|c|}{$\chi_{\mathrm{m}} \mathbf{T}\left(\mathrm{cm}^{3} \mathrm{~K} \mathrm{~mol}^{-1}\right)$} \\
\cline { 2 - 3 } & $\mathbf{C D C l}_{3}$ & $\mathbf{C D}_{2} \mathrm{Cl}_{2}$ \\
\hline 243 & 2.65628 & 2.21811 \\
\hline 248 & 2.77474 & 2.39608 \\
\hline 253 & 2.84513 & 2.54758 \\
\hline 258 & 2.90583 & 2.68156 \\
\hline 263 & 2.9777 & 2.79635 \\
\hline 268 & 3.03938 & 2.92637 \\
\hline 273 & 3.10145 & 3.02322 \\
\hline 278 & 3.15229 & 3.12216 \\
\hline 283 & 3.20302 & 3.19734 \\
\hline 288 & 3.25362 & 3.26017 \\
\hline 293 & 3.29165 & 3.29615 \\
\hline 298 & 3.32899 & 3.34217 \\
\hline 303 & 3.36566 & - \\
\hline 308 & 3.37494 & - \\
\hline 313 & 3.396 & - \\
\hline
\end{tabular}




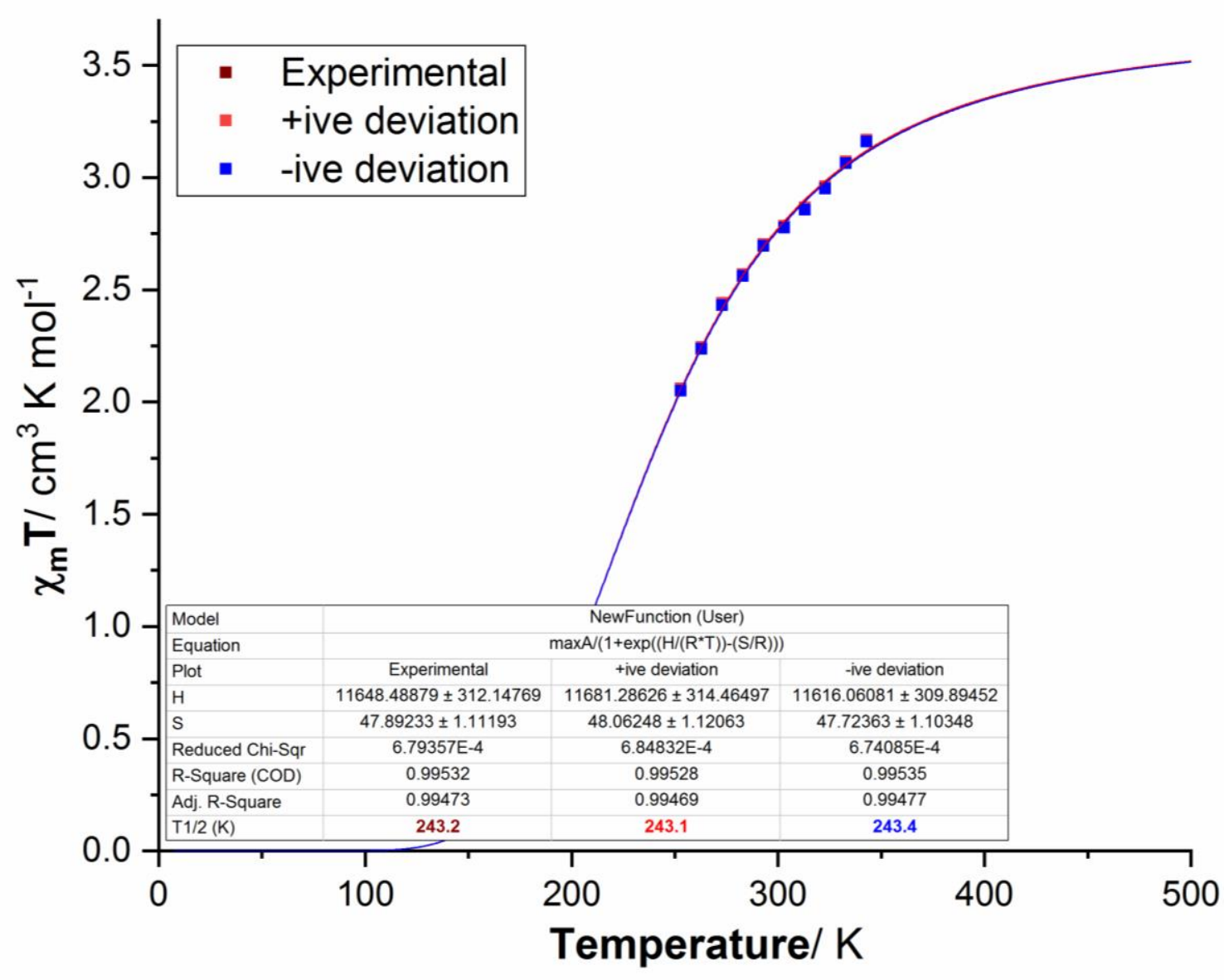

Figure S9. $\chi_{\mathrm{m}} \mathrm{T}$ vs $\mathrm{T}$ for $10.6 \mathrm{mM}$ of $\left[\mathrm{Fe}\left(\mathrm{L}^{\mathrm{LSIm}}\right)_{3}\right]\left(\mathrm{BF}_{4}\right)_{2}\left(2 \cdot 0.5 \mathrm{H}_{2} \mathrm{O}\right)$ in $\mathrm{CD}_{3} \mathrm{NO}_{2}$ solution from Evans method NMR studies ( $500 \mathrm{MHz}$ ); this graph displays the experimental data points (wine squares), and the $95 \%$ confidence intervals (red and blue) around the fit. 


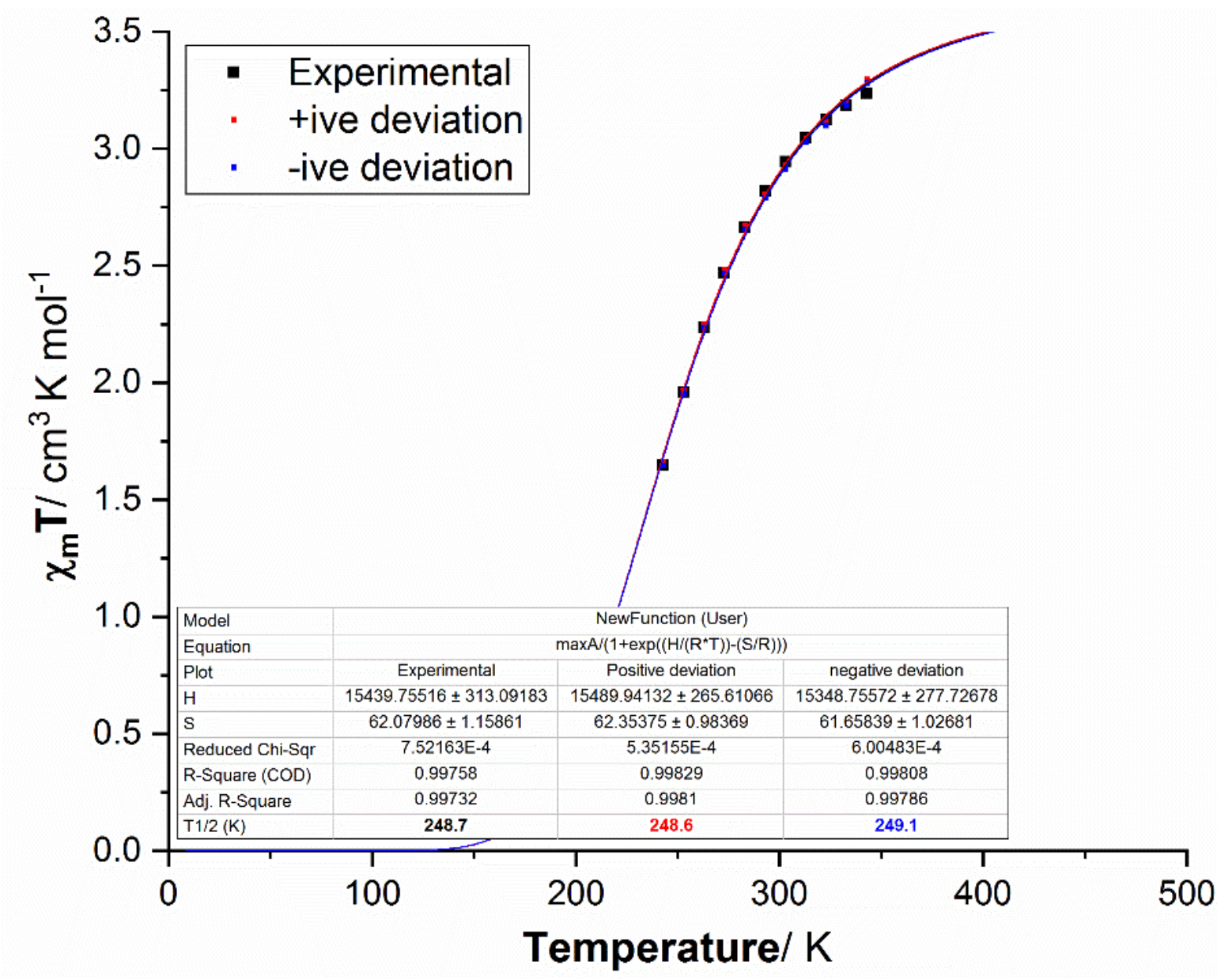

Figure S10. $\chi_{m} T$ vs $T$ for $10.6 \mathrm{mM}$ of $\left[\mathrm{Fe}\left(\mathrm{L}^{4 \mathrm{SIm}}\right)_{3}\right]\left(\mathrm{BF}_{4}\right)_{2}\left(\mathbf{2} \cdot 0.5 \mathrm{H}_{2} \mathrm{O}\right)$ in $\mathrm{CD}_{3} \mathrm{CN}$ solution from Evans NMR method studies $(500 \mathrm{MHz}$ ); this graph displays the experimental data points (black squares), and the 95\% confidence intervals (red and blue) around the fit. 


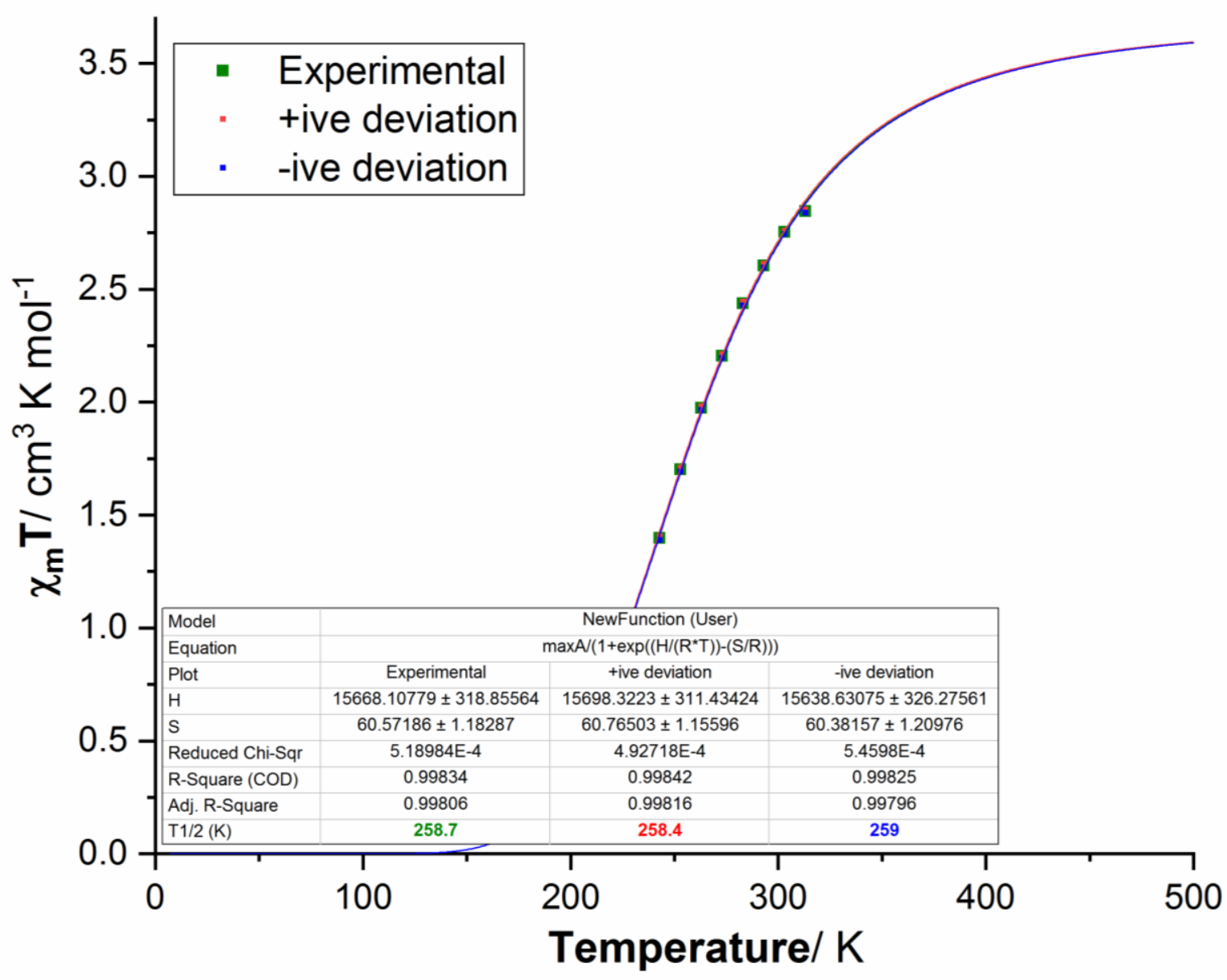

Figure S11. $\chi_{m} T$ vs $T$ for $10.6 \mathrm{mM}$ of $\left[\mathrm{Fe}\left(\mathrm{L}^{4 \mathrm{SIm}}\right)_{3}\right]\left(\mathrm{BF}_{4}\right)_{2}\left(2 \cdot 0.5 \mathrm{H}_{2} \mathrm{O}\right)$ in $\mathrm{C}_{2} \mathrm{D}_{6} \mathrm{CO}$ solution from Evans NMR method studies ( $500 \mathrm{MHz}$ ); this graph displays the experimental data points (green squares), and the 95\% confidence intervals (red and blue) around the fit. 


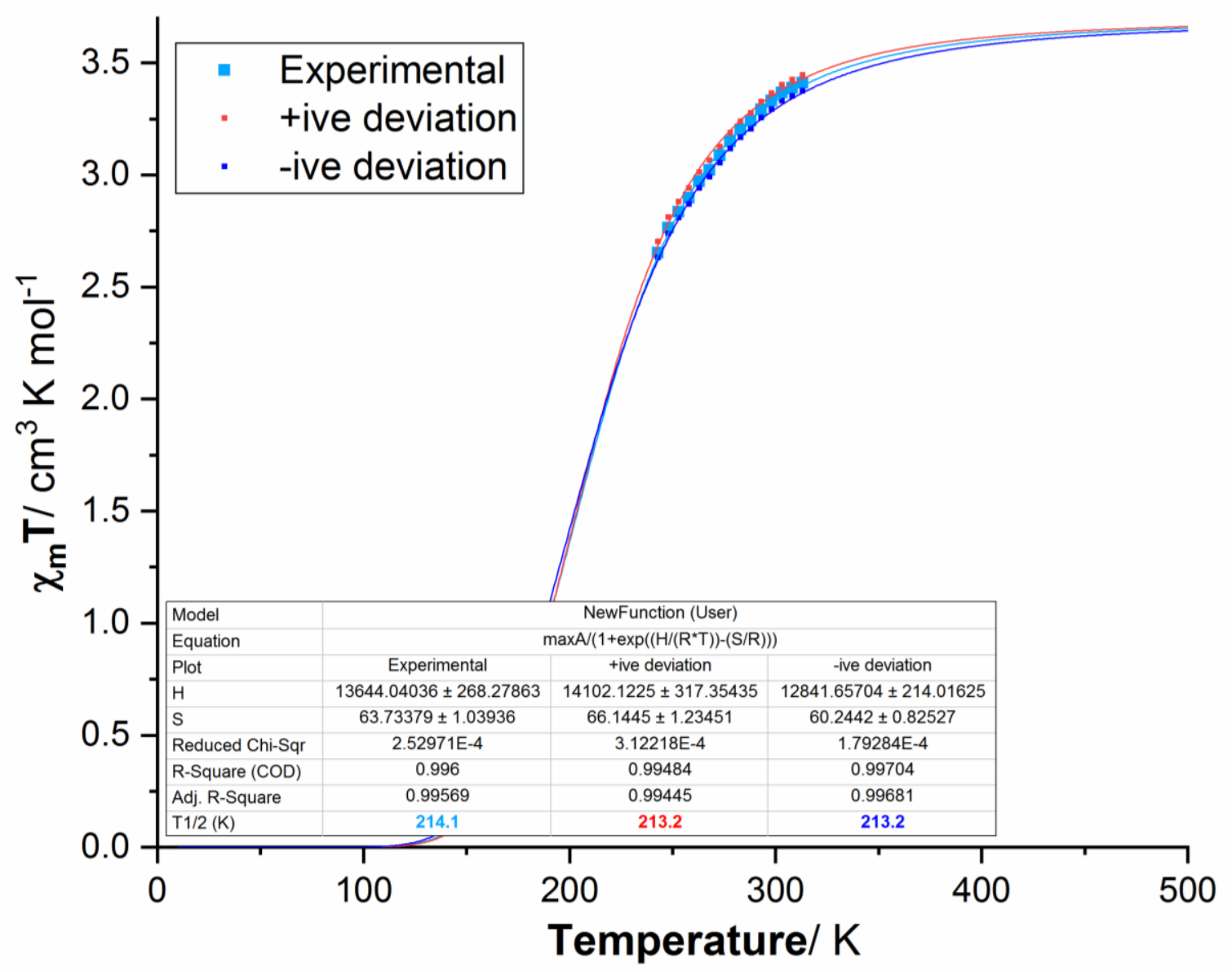

Figure S12. $\chi_{m} T$ vs $T$ for $10.6 \mathrm{mM}$ of $\left[\mathrm{Fe}\left(\mathrm{L}^{4 \mathrm{SIm}}\right)_{3}\right]\left(\mathrm{BF}_{4}\right)_{2}\left(2 \cdot 0.5 \mathrm{H}_{2} \mathrm{O}\right)$ in $\mathrm{CDCl}_{3}$ solution from Evans NMR method studies ( $500 \mathrm{MHz}$ ); this graph displays the experimental data points (sky blue squares), and the $95 \%$ confidence intervals (red and blue) around the fit. 


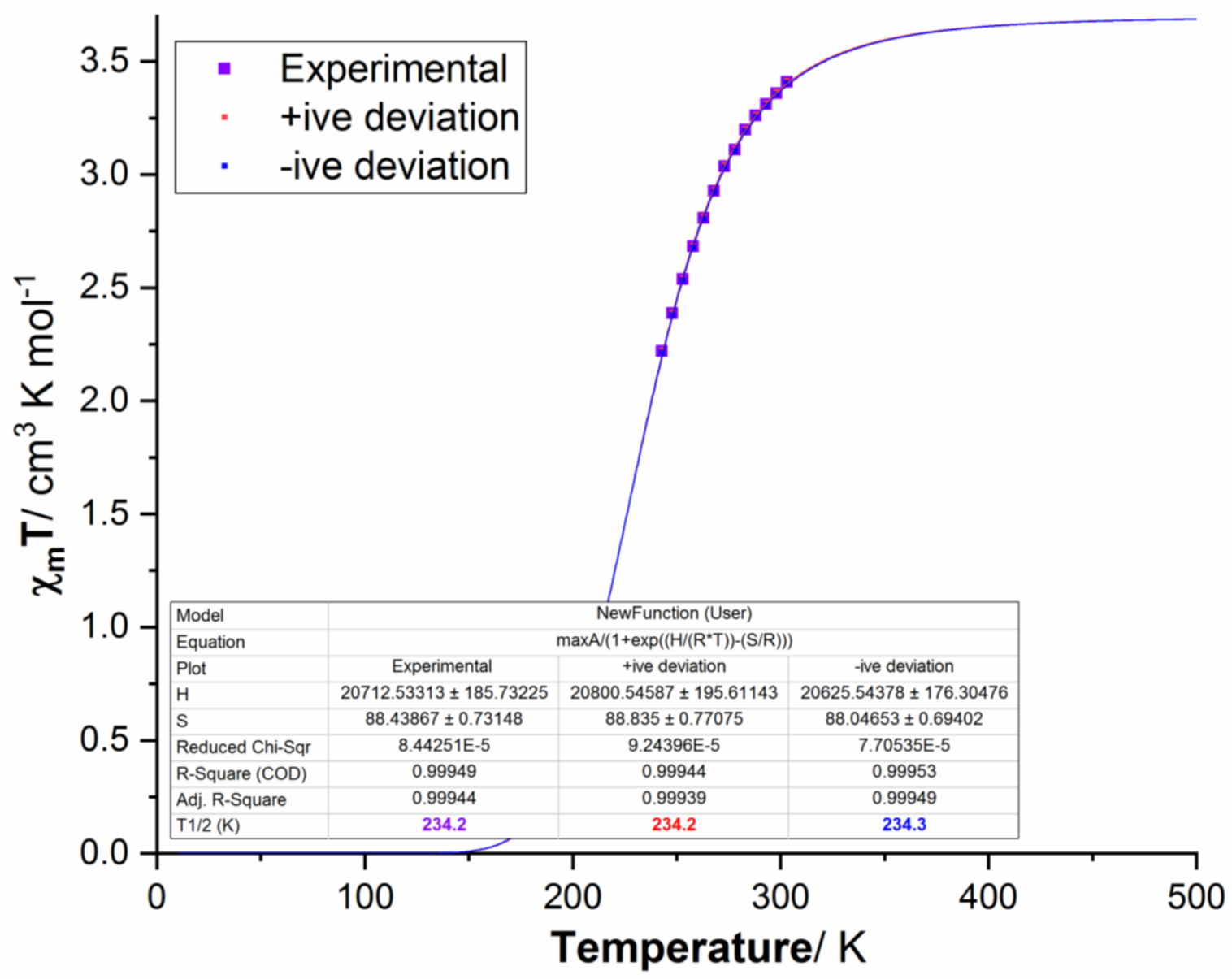

Figure S13. $\chi_{m} T$ vs $T$ for $10.6 \mathrm{mM}$ of $\left[\mathrm{Fe}\left(\mathrm{L}^{4 \mathrm{SIm}}\right)_{3}\right]\left(\mathrm{BF}_{4}\right)_{2}\left(\mathbf{2} \cdot 0.5 \mathrm{H}_{2} \mathrm{O}\right)$ in $\mathrm{CD}_{2} \mathrm{Cl}_{2}$ solution from Evans NMR method studies ( $500 \mathrm{MHz}$ ); this graph displays the experimental data points (purple squares), and the 95\% confidence intervals (red and blue) around the fit. 

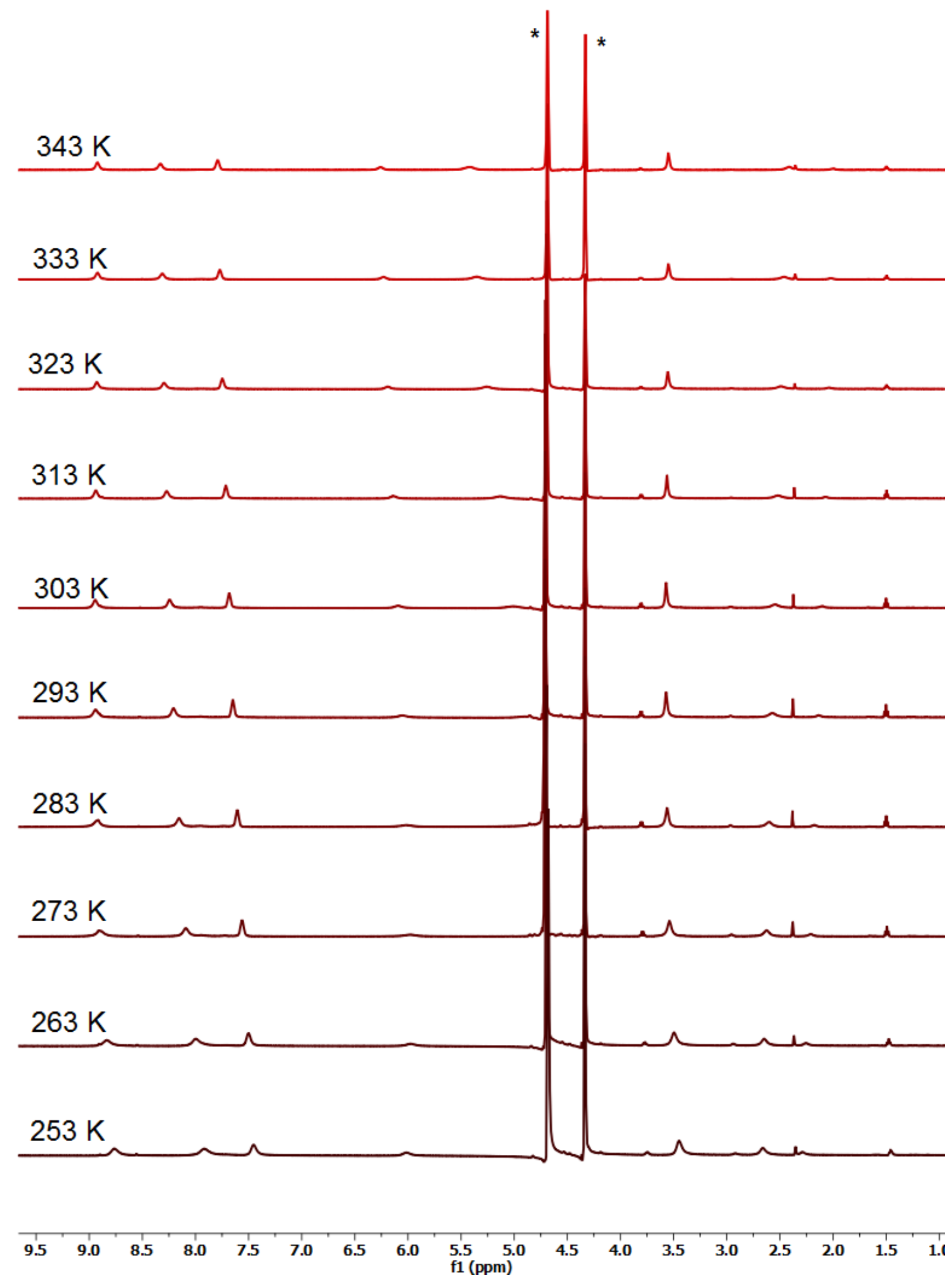

Figure S14. Stacked spectra, obtained by the Evans ${ }^{1} \mathrm{H}$ NMR method, from 343 to $253 \mathrm{~K}$ for complex $\left[\mathrm{Fe}\left(\mathrm{L}^{4 \mathrm{SIm}}\right)_{3}\right]\left(\mathrm{BF}_{4}\right)_{2}\left(2 \cdot 0.5 \mathrm{H}_{2} \mathrm{O}\right)$ in $\mathrm{CD}_{3} \mathrm{NO}_{2}(500 \mathrm{MHz})$ (* represent the solvent residual signal). 


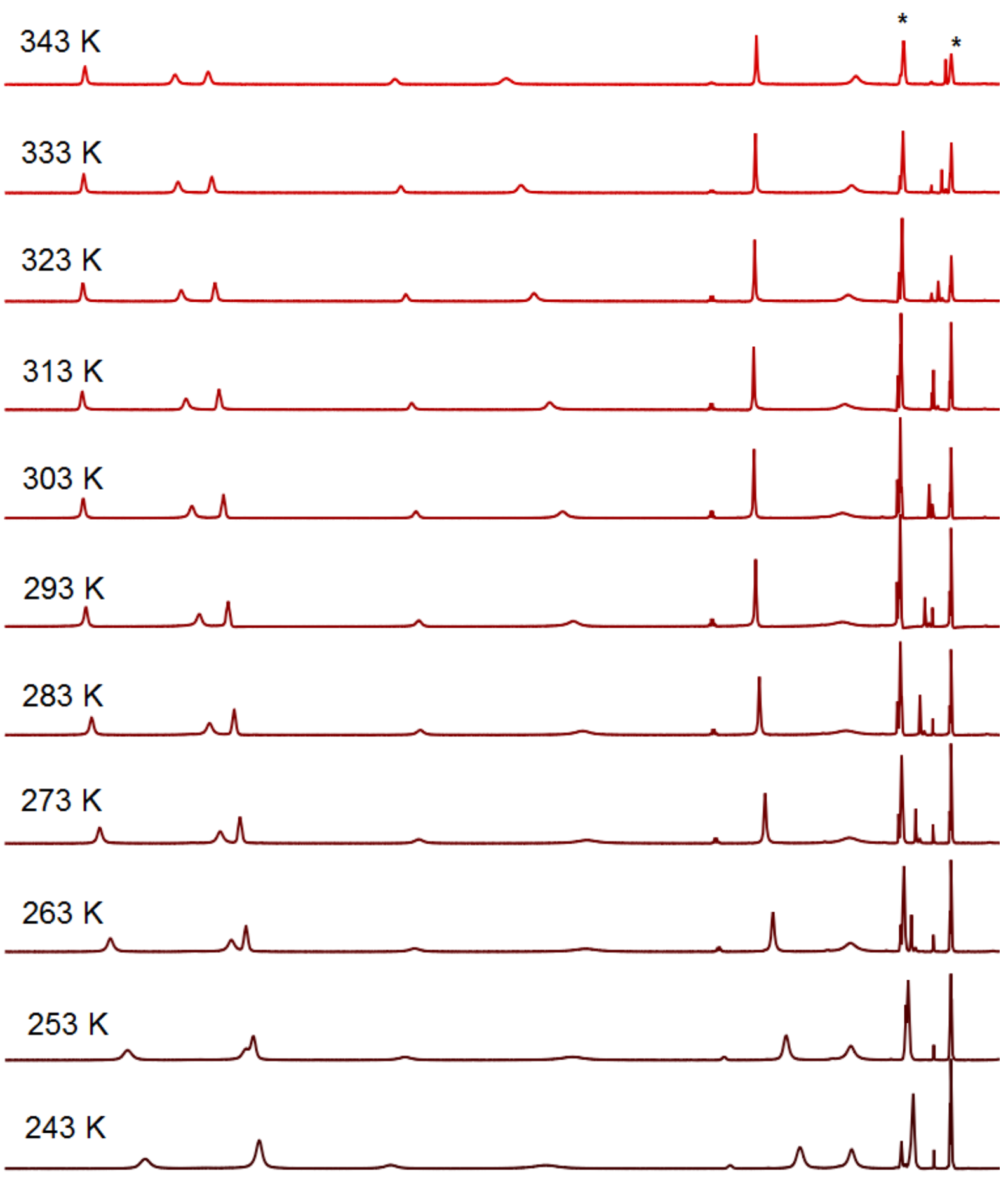

\begin{tabular}{|c|c|c|c|c|c|c|c|c|c|c|c|c|c|}
\hline 9.0 & 8.5 & 8.0 & 7.5 & 7.0 & 6.5 & 6.0 & $\begin{array}{l}5.5 \\
\text { f1 }(\mathrm{ppm})\end{array}$ & 5.0 & 4.5 & 4.0 & 3.5 & 3.0 & 2.5 \\
\hline
\end{tabular}

Figure S15. Stacked spectra, obtained by the Evans ${ }^{1} \mathrm{H}$ NMR method, from 343 to $243 \mathrm{~K}$ for complex $\left[\mathrm{Fe}\left(\mathrm{L}^{4 \mathrm{SIm}}\right)_{3}\right]\left(\mathrm{BF}_{4}\right)_{2}\left(2 \cdot 0.5 \mathrm{H}_{2} \mathrm{O}\right)$ in $\mathrm{CD}_{3} \mathrm{CN}(500 \mathrm{MHz})$ ( $^{*}$ represent the solvent residual signal). 

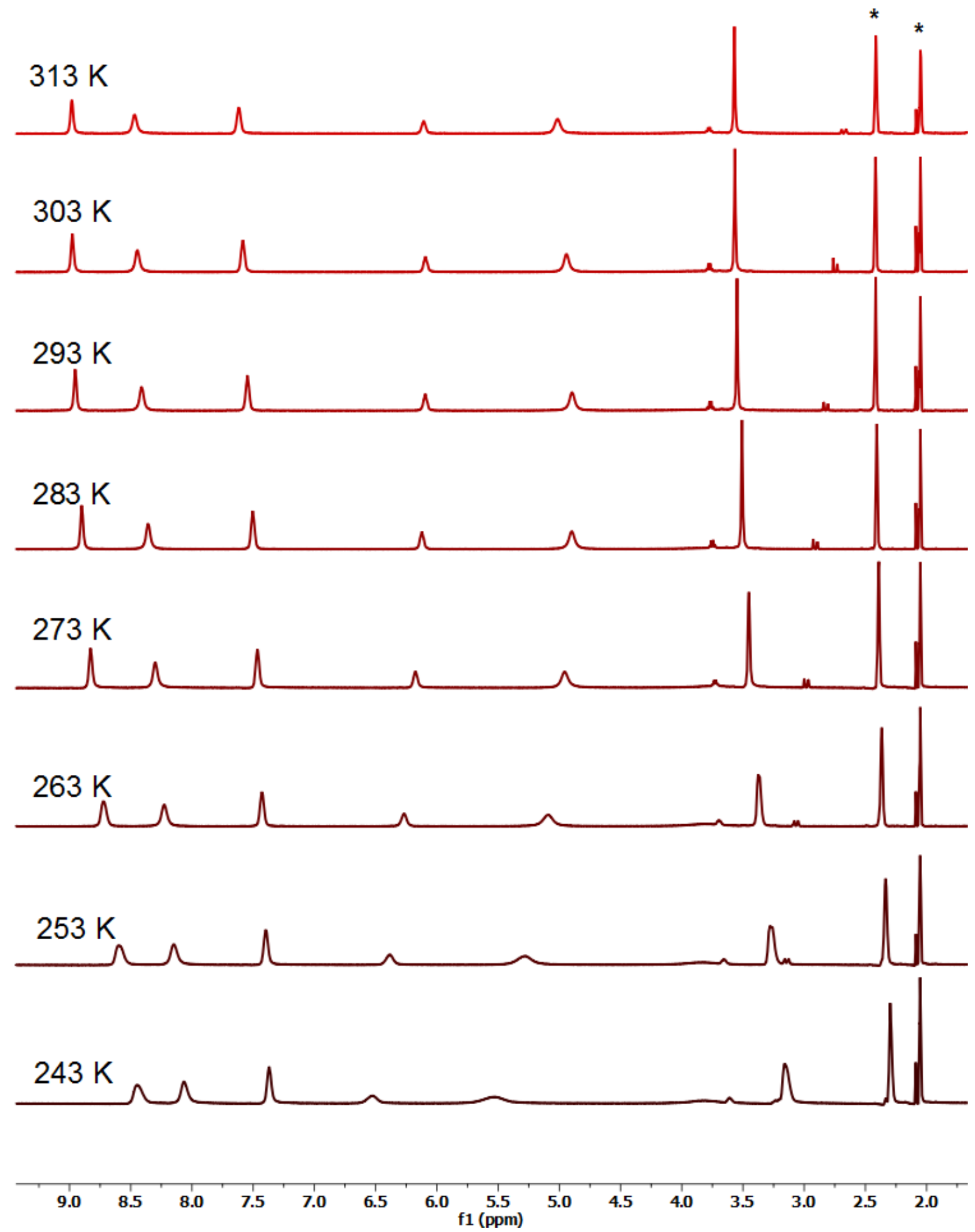

Figure S16. Stacked spectra, obtained by the Evans ${ }^{1} \mathrm{H}$ NMR method, from 313 to $243 \mathrm{~K}$ for complex $\left[\mathrm{Fe}\left(\mathrm{L}^{4 \mathrm{SIm}}\right)_{3}\right]\left(\mathrm{BF}_{4}\right)_{2}\left(\mathbf{2} \cdot 0.5 \mathrm{H}_{2} \mathrm{O}\right)$ in $\mathrm{C}_{2} \mathrm{D}_{6} \mathrm{CO}(500 \mathrm{MHz})(*$ represent the solvent residual signal). 


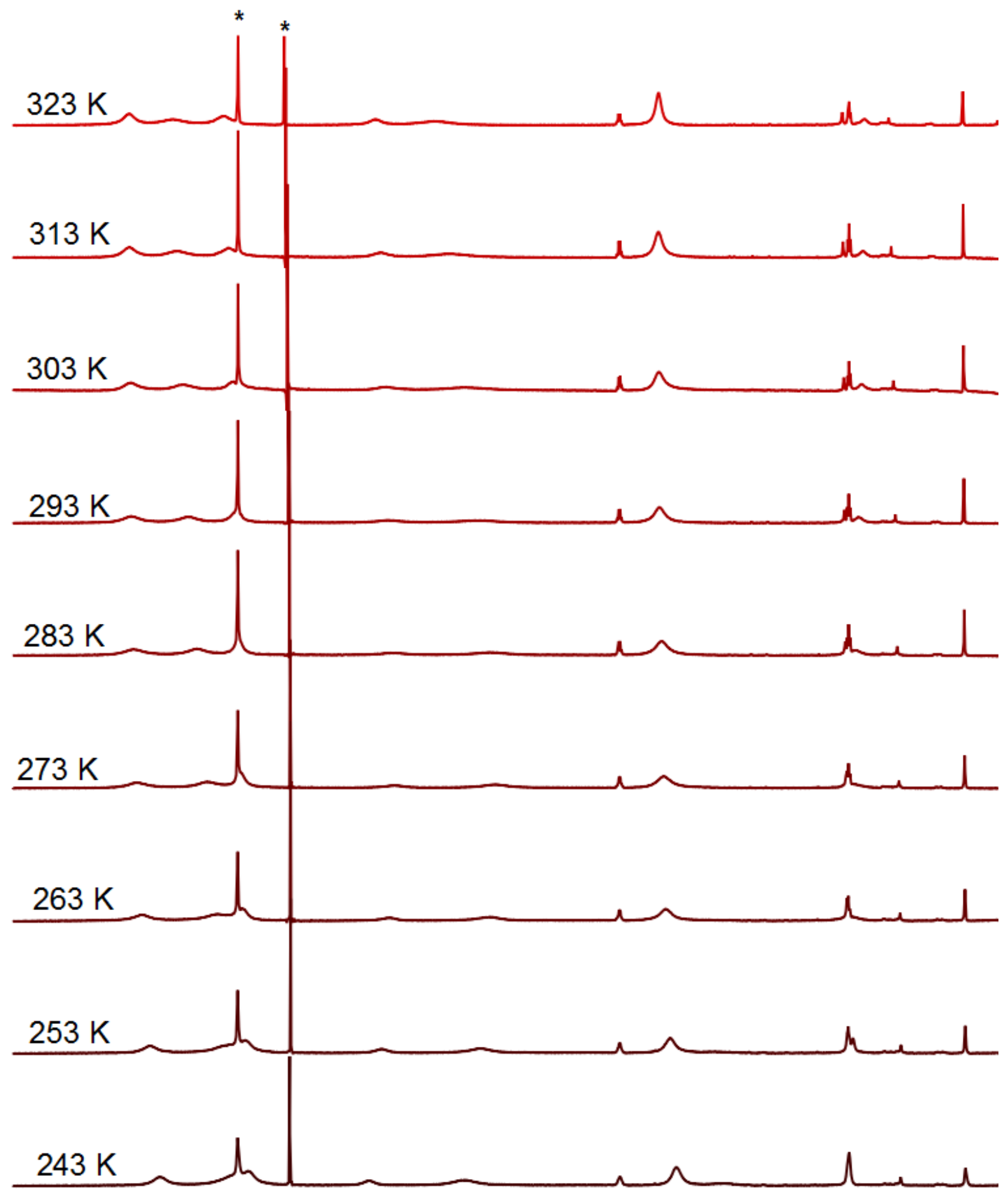

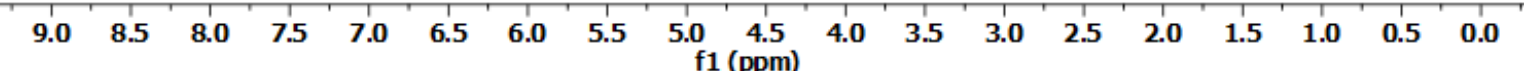

Figure S17. Stacked spectra, obtained by the Evans ${ }^{1} \mathrm{H}$ NMR method, from 313 to $243 \mathrm{~K}$ for complex $\left[\mathrm{Fe}\left(\mathrm{L}^{4 \mathrm{SIm}}\right)_{3}\right]\left(\mathrm{BF}_{4}\right)_{2}\left(2 \cdot 0.5 \mathrm{H}_{2} \mathrm{O}\right)$ in $\mathrm{CDCl}_{3}(500 \mathrm{MHz})$ (* represent the solvent residual signal). 


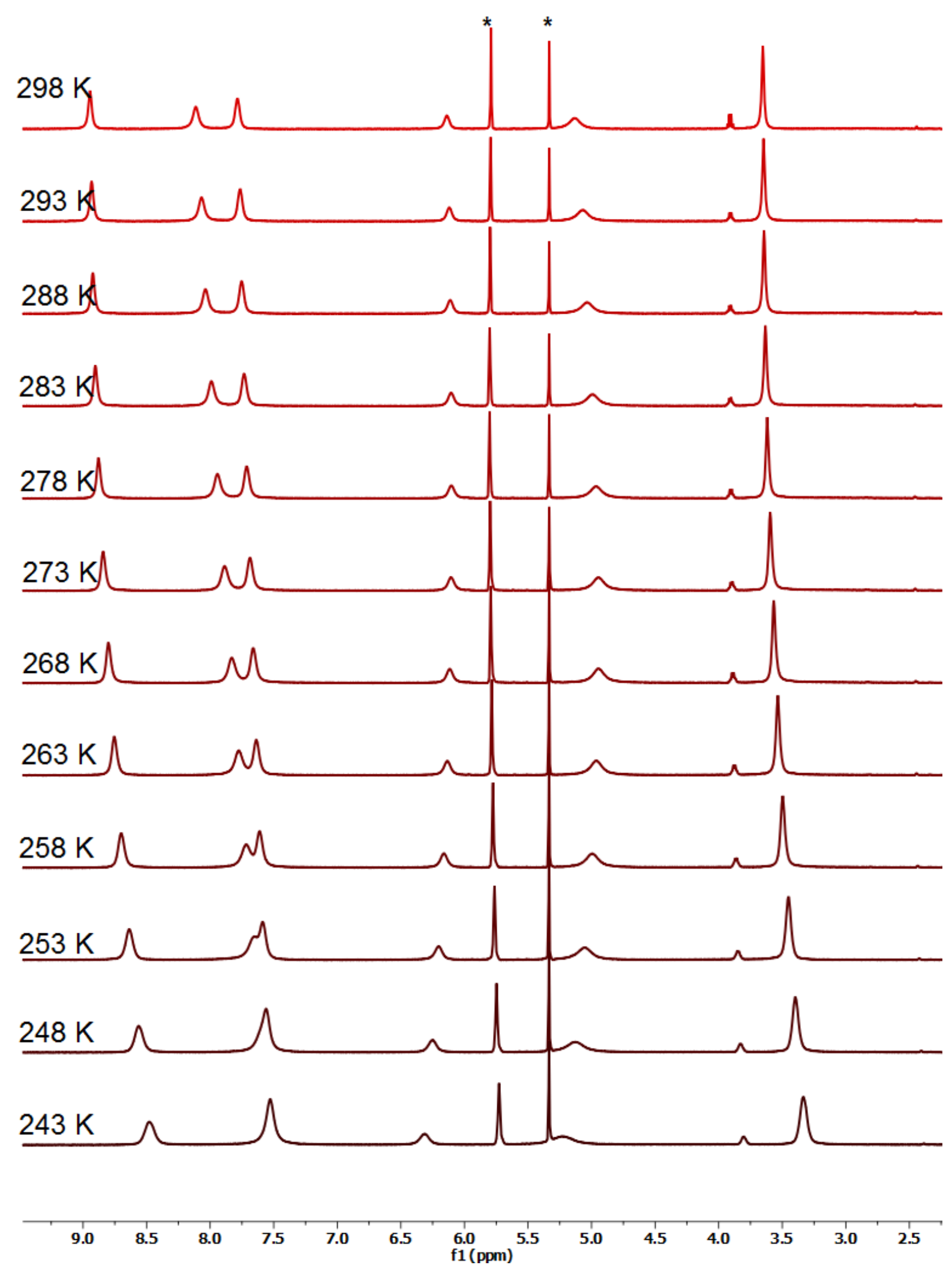

Figure S18. Stacked spectra, obtained by the Evans ${ }^{1} \mathrm{H}$ NMR method, from 298 to $243 \mathrm{~K}$ for complex $\left[\mathrm{Fe}\left(\mathrm{L}^{4 \mathrm{SIm}}\right)_{3}\right]\left(\mathrm{BF}_{4}\right)_{2}\left(\mathbf{2} \cdot 0.5 \mathrm{H}_{2} \mathrm{O}\right)$ in $\mathrm{CD}_{2} \mathrm{Cl}_{2}(500 \mathrm{MHz})$ (* represent the solvent residual signal). 


\section{Possible correlations between solution $\mathrm{T}_{1 / 2}$ and different solvent properties}

Table S10. Tabulated values of the different solvent and their physical parameters. The parameters are dimensionless, if not stated.

\begin{tabular}{|c|c|c|c|c|c|c|c|c|}
\hline solvent & $P^{\prime 5,6}[a]$ & $\begin{array}{l}P^{\prime 6} \\
{[b]}\end{array}$ & $E_{T}^{N 7}$ & Basity $^{8,9}$ & $\delta\left(\mathrm{MPa}^{1 / 2}\right)^{10}$ & $\varepsilon_{r}^{11}$ & $\mu(D)$ & $\begin{array}{l}T_{1 / 2}(K) \text { of } \\
2 \cdot 0.5 \mathrm{H}_{2} \mathrm{O}\end{array}$ \\
\hline $\mathrm{CH}_{3} \mathrm{NO}_{2}$ & 6.8 & 6.8 & 0.481 & 0.92 & 26.0 & 37.27 & 3.46 & 239 \\
\hline $\mathrm{CH}_{3} \mathrm{CN}$ & 5.8 & 6.2 & 0.460 & 0.86 & 24.3 & 36.64 & 3.44 & 247 \\
\hline $\mathrm{C}_{2} \mathrm{H}_{6} \mathrm{CO}$ & 5.1 & 5.4 & 0.355 & 0.81 & 20.3 & 21.01 & 2.69 & 255 \\
\hline $\mathrm{CHCl}_{3}$ & 4.1 & 4.3 & 0.259 & 0.73 & 19.0 & 4.81 & 1.15 & 217 \\
\hline $\mathrm{CH}_{2} \mathrm{Cl}_{2}$ & 3.1 & 3.4 & 0.309 & 0.80 & 19.8 & 8.93 & 1.14 & 234 \\
\hline
\end{tabular}

a: The polarity index $\left(\mathrm{P}^{\prime}\right)$ is an empirical parameter that gives a relative measure of the degree of interaction of the solvent molecule with various polar test solutes ethanol, dioxane and nitromethane. $\mathrm{P}^{\prime}$ for $\mathrm{CH}_{3} \mathrm{CN}, \mathrm{C}_{2} \mathrm{H}_{6} \mathrm{CO}, \mathrm{CHCl}_{3}, \mathrm{CH}_{2} \mathrm{Cl}_{2}$ reported by Ahuja in $2003^{5}$ whereas $\mathrm{CH}_{3} \mathrm{NO}_{2}$ is reported by Schirmer in $1990^{6}$. Plotted in the main paper, Figure 6.

b: These $P^{\prime}$ values reported by Schirmer. ${ }^{6}$

$E_{T}^{N}$ : The Reichardt's $E_{T}^{N}$ (Normalized molar electronic transition energies) is an empirical solvent polarity parameter. ${ }^{7}$

Basity: Swain and co-workers' Basity parameter represents the cation-solvating tendency, the hydrogen bonding basicity and nucleophilic properties of a solvent. ${ }^{8,9}$

$\delta$ : The Hildebrand's solvent solubility parameter, $\delta\left(\mathrm{MPa}^{1 / 2}\right)$ is used as an indicator of solvent polarity for regular solutions. ${ }^{10} \delta$ is obtained by the addition of three polar interactions such as dispersion, polar and hydrogen interactions.

$\varepsilon_{\mathrm{r}}: \varepsilon_{\mathrm{r}}$ is the relative permittivity or dielectric constant of the solvent.

$\mu: \mu(D)$ is the dipole moment of the solvent.

Table S11. $R^{2}$ values for the $T_{1 / 2}$ values of complexes $\left[\mathrm{Fe}\left(1 \mathrm{~L}^{45 \mathrm{~m}}\right)_{3}\right]\left(\mathrm{BF}_{4}\right)_{2} \cdot 0.5 \mathrm{H}_{2} \mathrm{O}\left(\mathbf{2} \cdot 0.5 \mathrm{H}_{2} \mathrm{O}\right)$ versus the solvent's physical parameters of the five solvents used in this study.

\begin{tabular}{|l|l|}
\hline$T_{1 / 2}$ VS parameters & $\mathbf{R}^{2}$ \\
\hline$T_{1 / 2}$ Vs $P^{\prime 5,6}$ & 0.25 \\
\hline$T_{1 / 2}$ Vs $P^{\prime 6}$ & 0.30 \\
\hline$T_{1 / 2}$ VS $\varepsilon_{r}$ & 0.44 \\
\hline$T_{1 / 2}$ VS $\mu$ & 0.53 \\
\hline$T_{1 / 2}$ Vs $E_{T}^{N}$ & 0.40 \\
\hline$T_{1 / 2}^{N}$ Vs $\delta$ & 0.19 \\
\hline$T_{1 / 2}$ Vs Basity & 0.37 \\
\hline
\end{tabular}


Table S12. Tabulated values of the different solvent and their physical parameters; Acity ${ }^{8,9}, \alpha^{8,12}, \beta^{8,}$ ${ }^{12}, \pi^{* 8,12}, \mathrm{SB}^{13}, \mathrm{SA}^{13}, \mathrm{DN}^{14,15}, \mathrm{AN}^{14,15}$. The parameters are dimensionless, if not stated.

\begin{tabular}{|c|c|c|c|c|c|c|c|c|c|}
\hline solvent & Acity $^{8,9}$ & $\alpha^{8,12}$ & $\beta^{8,12}$ & $\pi^{* 8,12}$ & $\mathrm{SB}^{13}$ & $S A^{13}$ & $\mathrm{DN}^{14,15}$ & $\mathrm{AN}^{14,15}$ & $\begin{array}{l}T_{1 / 2}(K) \text { of } \\
2 \cdot 0.5 \mathrm{H}_{2} \mathrm{O}\end{array}$ \\
\hline $\mathrm{CH}_{3} \mathrm{NO}_{2}$ & 0.39 & 0.22 & 0.06 & 0.85 & 0.236 & 0.078 & 2.7 & 20.5 & 243 \\
\hline $\mathrm{CH}_{3} \mathrm{CN}$ & 0.37 & 0.19 & 0.4 & 0.75 & 0.286 & 0.044 & 14.1 & 18.9 & 249 \\
\hline $\mathrm{C}_{2} \mathrm{H}_{6} \mathrm{CO}$ & 0.25 & 0.08 & 0.43 & 0.71 & 0.475 & 0 & 17 & 12.5 & 259 \\
\hline $\mathrm{CHCl}_{3}$ & 0.42 & 0.1 & 0.2 & 0.58 & 0.071 & 0.047 & 4 & 23.1 & 214 \\
\hline $\mathrm{CH}_{2} \mathrm{Cl}_{2}$ & 0.33 & 0.13 & 0.1 & 0.82 & 0.178 & 0.04 & 1 & 20.4 & 234 \\
\hline
\end{tabular}

Acity: The Swain and co-workers' acity parameter represents the anion-solvating tendency, the hydrogen bonding acidity and the electrophilic properties of a solvent. ${ }^{8,9}$

$\alpha$ : The Kamlet and Taft's $\alpha$ parameter describes solvents based on their hydrogen-bond donor acidities, i.e the ability of the solvent to donate a proton in a solvent-to-solute hydrogen bond. ${ }^{8,12}$

$\beta$ : the $\beta$ parameter describes solvents based on their hydrogen-bond acceptor basicities which provides a measure of the solvent's ability to accept a proton (donate an electron pair) in a solute-tosolvent hydrogen bond. ${ }^{8,12}$

$\pi^{*}$ : The $\pi^{*}$ parameter is an index of solvent dipolarity/polarizability, which measures the ability of the solvent to stabilize a charge or a dipole by virtue of its dielectric effect. ${ }^{8,12}$

SB: Catalan and co-workers' Solvent Basicity (SB) parameter classifies the basicity of solvents based on their hydrogen-bond acceptor ability. ${ }^{13}$

SA: the Solvent Acidity (SA) parameter describes the acidity of solvents based on their hydrogen-bond donating ability. ${ }^{13}$

DN: The Gutmann's Donor Number (DN) is an empirical parameter used to describe the donor strength of a given solvent. ${ }^{14,15}$

AN: The Mayer and Gutmann' Acceptor Number (AN) is an empirical parameter that measures the electrophilic properties of solvents. ${ }^{14,15}$

Table S13. $\mathrm{R}^{2}$ values for the $\mathrm{T}_{1 / 2}$ values of complexes $\left[\mathrm{Fe}^{\prime \prime}\left(\mathrm{L}^{4 \mathrm{sIm}}\right)_{3}\right]\left(\mathrm{BF}_{4}\right)_{2} \cdot 0.5 \mathrm{H}_{2} \mathrm{O}\left(\mathbf{2} \cdot 0.5 \mathrm{H}_{2} \mathrm{O}\right)$ versus the solvent's physical parameters of the five solvents used in this study.

\begin{tabular}{|l|l|}
\hline$T_{1 / 2}$ Vs parameters & $\mathbf{R}^{2}$ \\
\hline$T_{1 / 2}$ Vs Acity & 0.54 \\
\hline$T_{1 / 2}$ VS $\alpha$ & 0.02 \\
\hline$T_{1 / 2}$ Vs $\beta$ & 0.30 \\
\hline$T_{1 / 2}$ VS $\pi^{*}$ & 0.24 \\
\hline$T_{1 / 2}$ VS SB & 0.90 \\
\hline$T_{1 / 2}$ VS SA & 0.17 \\
\hline$T_{1 / 2}$ VS DN & 0.51 \\
\hline$T_{1 / 2}$ Vs AN & 0.75 \\
\hline
\end{tabular}




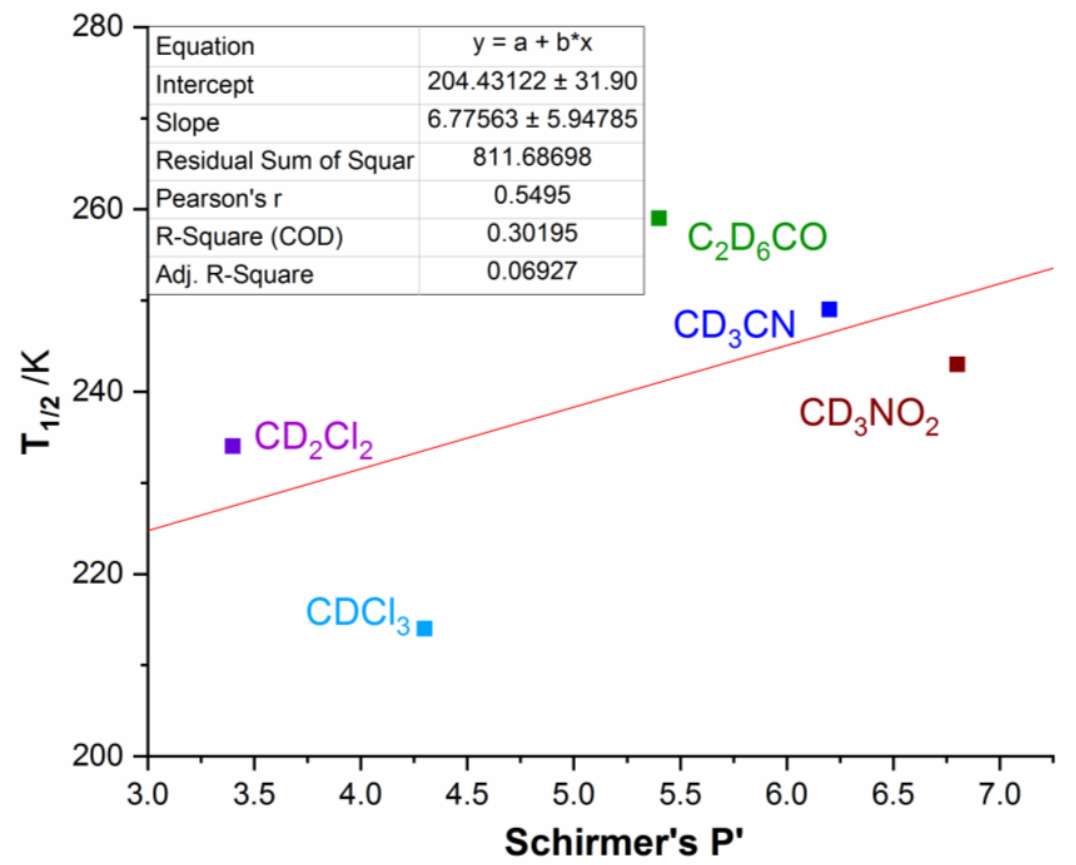

Figure S19. Plot showing the lack of correlation $\left(R^{2}=0.30\right)$ between solution $T_{1 / 2}$ values for the salt, $\left[\mathrm{Fe}^{\prime \prime}\left(\mathrm{L}^{4 \mathrm{SIm}}\right)_{3}\right]\left(\mathrm{BF}_{4}\right)_{2} \cdot 0.5 \mathrm{H}_{2} \mathrm{O}\left(\mathbf{2} \cdot 0.5 \mathrm{H}_{2} \mathrm{O}\right)$, and the Schirmer's polarity index $\left(P^{\prime}\right)$ of the solvent used. ${ }^{6}$

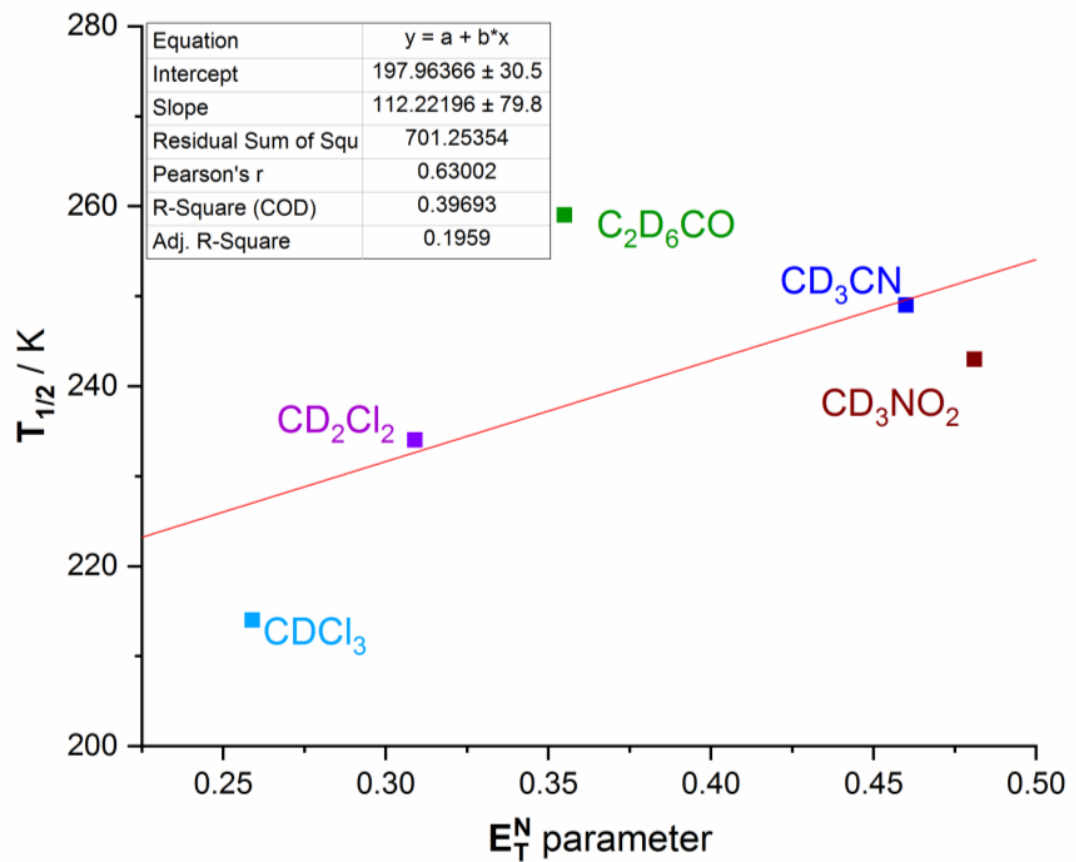

Figure S20. Plot showing the lack of correlation $\left(R^{2}=0.40\right)$ between solution $T_{1 / 2}$ values for the salt, $\left[\mathrm{Fe}^{\mathrm{II}}\left(\mathrm{L}^{\mathrm{LSI} \mathrm{m}}\right)_{3}\right]\left(\mathrm{BF}_{4}\right)_{2} \cdot 0.5 \mathrm{H}_{2} \mathrm{O}\left(\mathbf{2} \cdot 0.5 \mathrm{H}_{2} \mathrm{O}\right)$, and the Reichardt's $E_{T}^{N}$ parameter of the solvent used. ${ }^{7}$ 


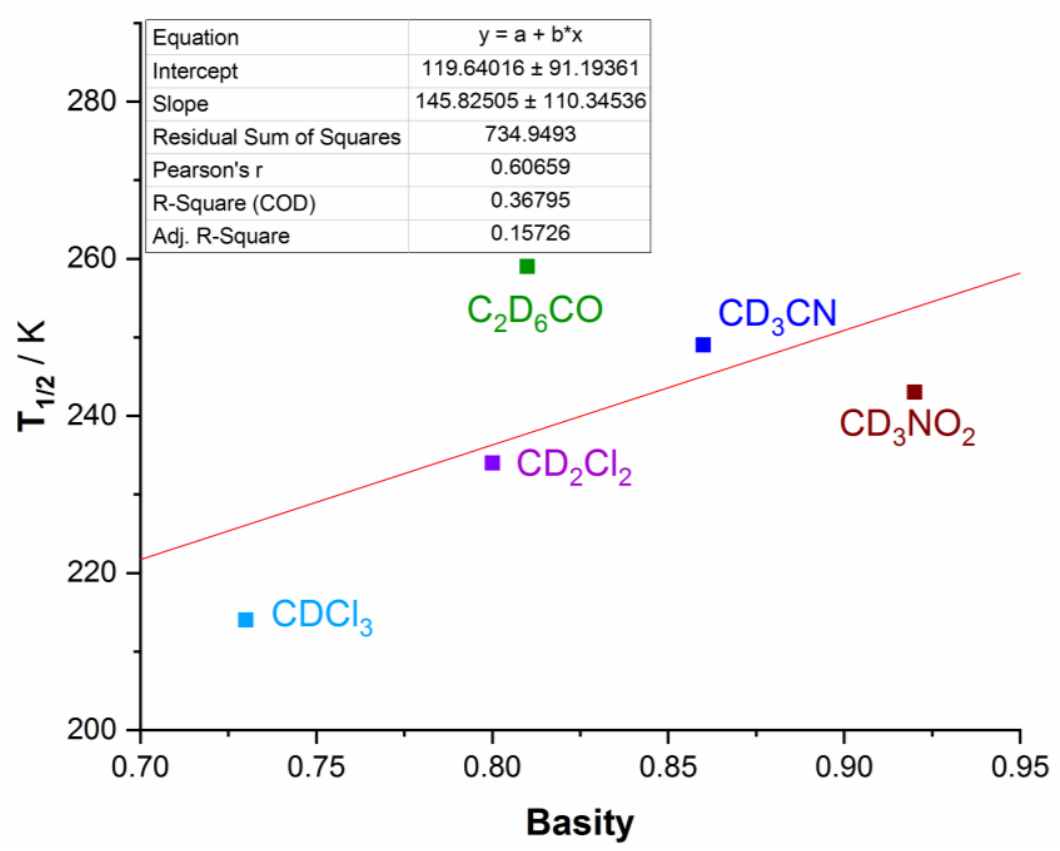

Figure S21. Plot showing the lack of correlation $\left(R^{2}=0.37\right)$ between solution $T_{1 / 2}$ values for the salt, $\left[\mathrm{Fe}^{\prime \prime}\left(\mathrm{L}^{4 \mathrm{SIm}}\right)_{3}\right]\left(\mathrm{BF}_{4}\right)_{2} \cdot 0.5 \mathrm{H}_{2} \mathrm{O}\left(2 \cdot 0.5 \mathrm{H}_{2} \mathrm{O}\right)$, and the Basity parameter reported by Swain and co-workers' of the solvent used..$^{8,9}$

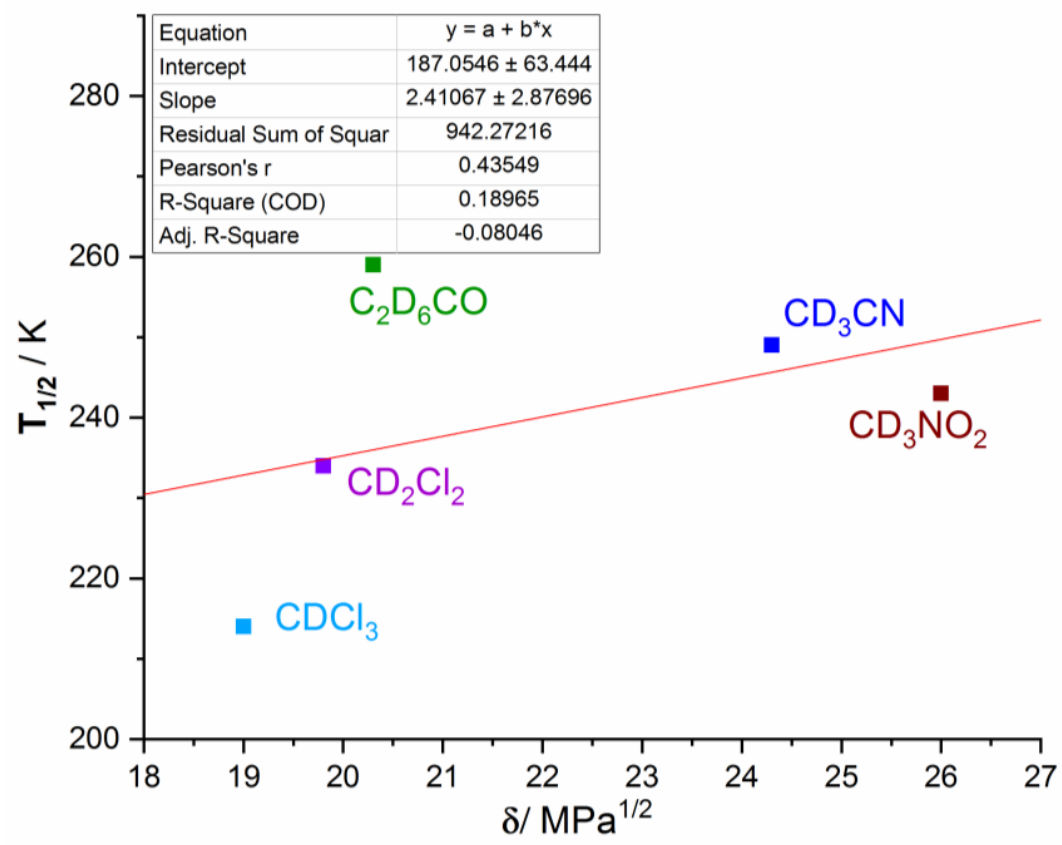

Figure S22. Plot showing the lack of correlation $\left(R^{2}=0.19\right)$ between solution $T_{1 / 2}$ values for the salt, $\left[\mathrm{Fe}^{\prime \prime}\left(\mathrm{L}^{4 \mathrm{SIm}}\right)_{3}\right]\left(\mathrm{BF}_{4}\right)_{2} \cdot 0.5 \mathrm{H}_{2} \mathrm{O}\left(\mathbf{2} \cdot 0.5 \mathrm{H}_{2} \mathrm{O}\right)$, and the Hildebrand's solubility parameter $(\delta)$ of the solvent used. ${ }^{10}$ 


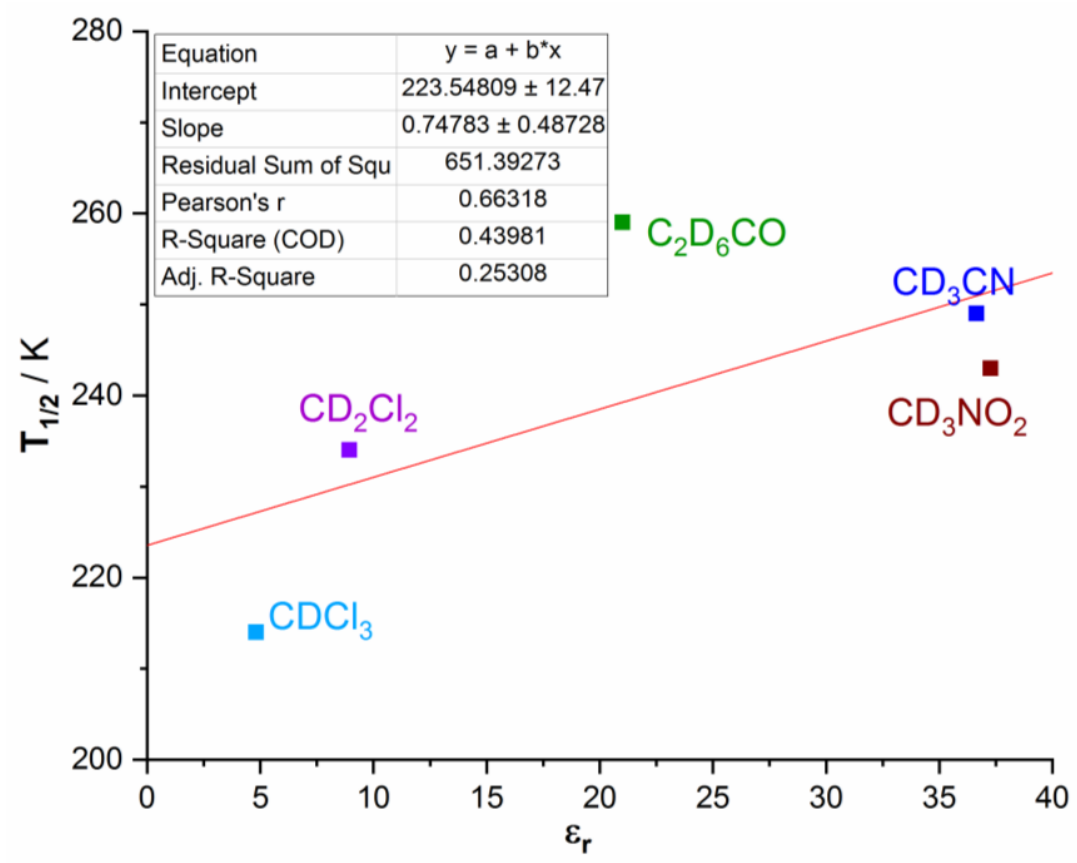

Figure S23. Plot showing the lack of correlation $\left(R^{2}=0.44\right)$ between solution $T_{1 / 2}$ values for the salt, $\left[\mathrm{Fe}^{\prime \prime}\left(\mathrm{L}^{4 S \mathrm{Im}}\right)_{3}\right]\left(\mathrm{BF}_{4}\right)_{2} \cdot 0.5 \mathrm{H}_{2} \mathrm{O}\left(\mathbf{2} \cdot 0.5 \mathrm{H}_{2} \mathrm{O}\right)$, and the relative permittivity or dielectric constant $\left(\varepsilon_{\mathrm{r}}\right)$ of the solvent used. ${ }^{11}$

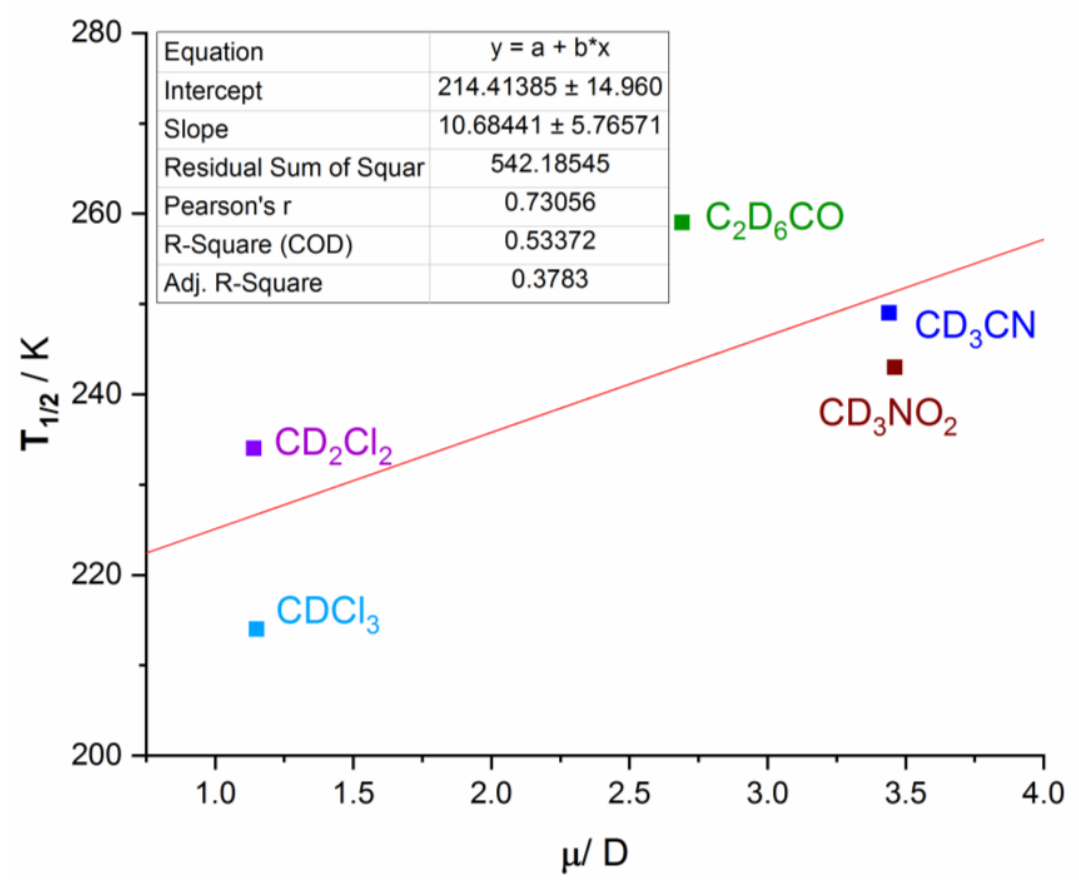

Figure S24. Plot showing the lack of correlation $\left(R^{2}=0.53\right)$ between solution $T_{1 / 2}$ values for the salt, $\left[\mathrm{Fe}^{\prime \prime}\left(\mathrm{L}^{4 \mathrm{SIm}}\right)_{3}\right]\left(\mathrm{BF}_{4}\right)_{2} \cdot 0.5 \mathrm{H}_{2} \mathrm{O}\left(\mathbf{2} \cdot 0.5 \mathrm{H}_{2} \mathrm{O}\right)$, and the dipole moment $(\mu)$ of the solvent used. 


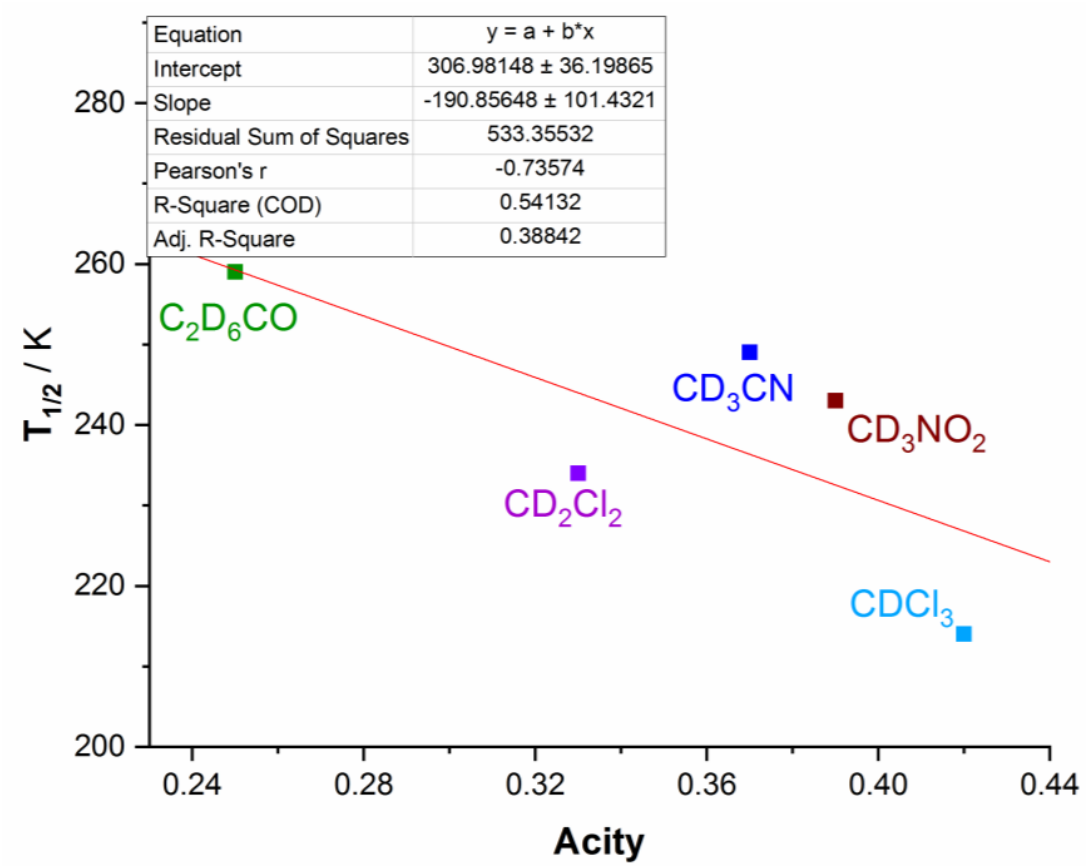

Figure S25. Plot showing the lack of correlation $\left(R^{2}=0.54\right)$ between solution $T_{1 / 2}$ values for the salt, $\left[\mathrm{Fe}^{\mathrm{II}}\left(\mathrm{L}^{\mathrm{4SIm}}\right)_{3}\right]\left(\mathrm{BF}_{4}\right)_{2} \cdot 0.5 \mathrm{H}_{2} \mathrm{O}\left(2 \cdot 0.5 \mathrm{H}_{2} \mathrm{O}\right)$, and the Acity of the solvent used.

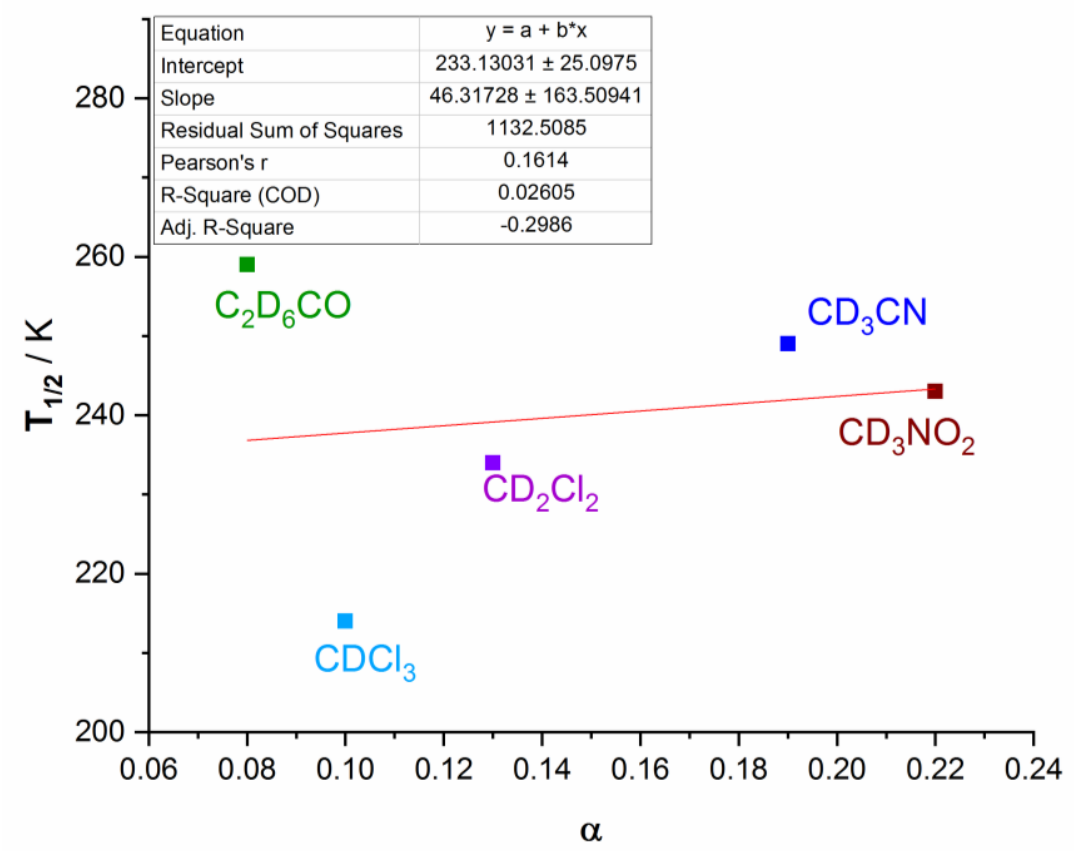

Figure S26. Plot showing the lack of correlation $\left(R^{2}=0.02\right)$ between solution $T_{1 / 2}$ values for the salt, $\left[\mathrm{Fe}^{\prime \prime}\left(\mathrm{L}^{4 \mathrm{sim}}\right)_{3}\right]\left(\mathrm{BF}_{4}\right)_{2} \cdot 0.5 \mathrm{H}_{2} \mathrm{O}\left(\mathbf{2} \cdot 0.5 \mathrm{H}_{2} \mathrm{O}\right)$, and the Kamlet and Taft's $\alpha$ of the solvent used. 


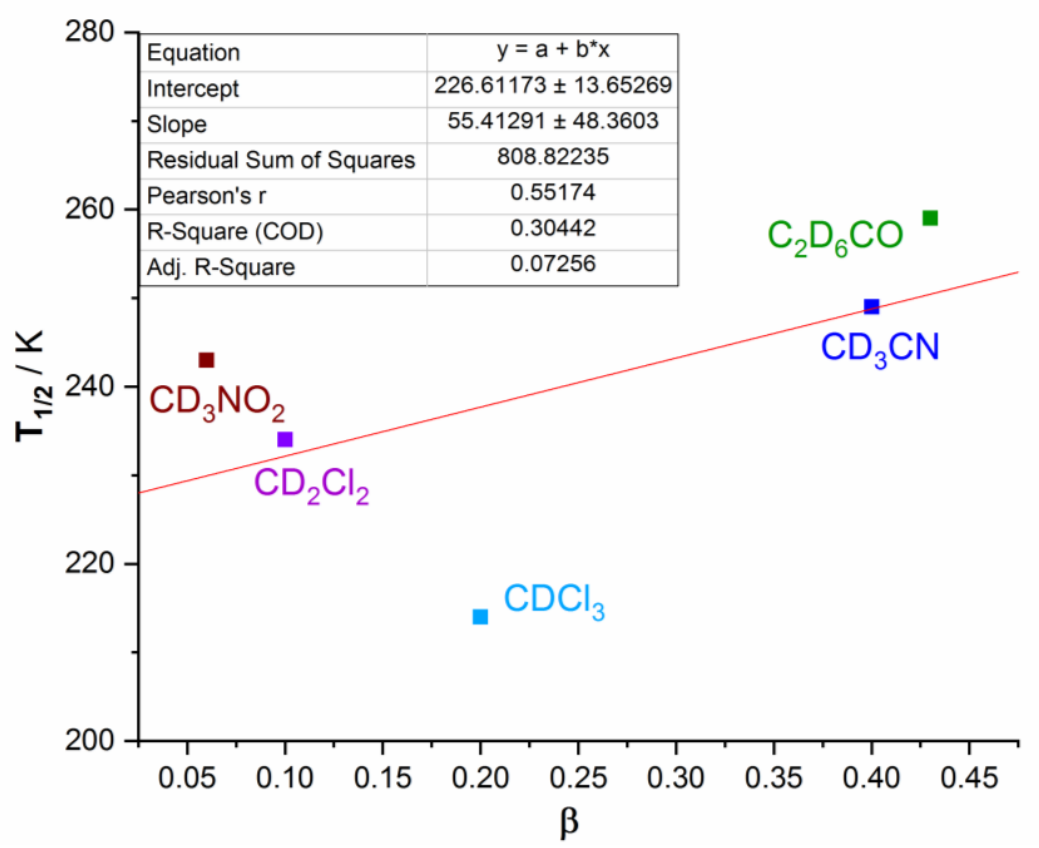

Figure S27. Plot showing the lack of correlation $\left(R^{2}=0.30\right)$ between solution $T_{1 / 2}$ values for the salt, $\left[\mathrm{Fe}^{\prime \prime}\left(\mathrm{L}^{4 \mathrm{SIm}}\right)_{3}\right]\left(\mathrm{BF}_{4}\right)_{2} \cdot 0.5 \mathrm{H}_{2} \mathrm{O}\left(2 \cdot 0.5 \mathrm{H}_{2} \mathrm{O}\right)$, and the $\beta$ of the solvent used.

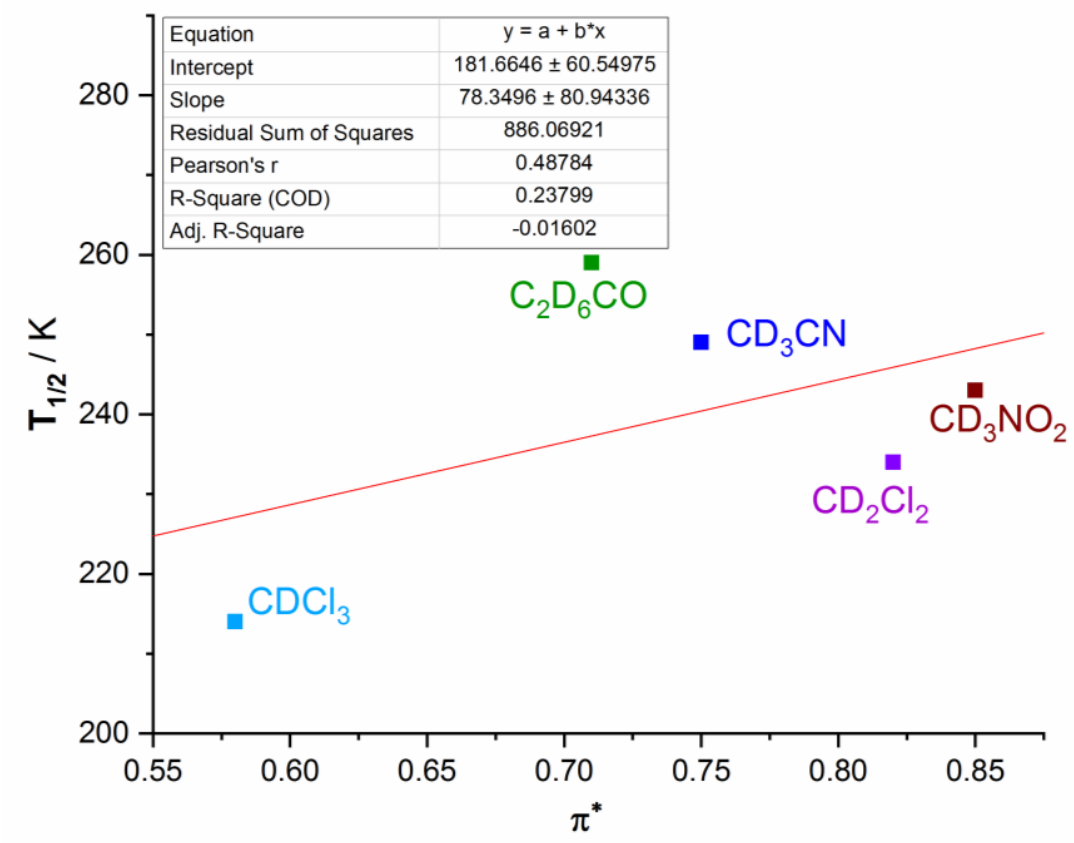

Figure S28. Plot showing the lack of correlation $\left(R^{2}=0.24\right)$ between solution $T_{1 / 2}$ values for the salt, $\left[\mathrm{Fe}^{\mathrm{II}}\left(\mathrm{L}^{4 \mathrm{SIm}}\right)_{3}\right]\left(\mathrm{BF}_{4}\right)_{2} \cdot 0.5 \mathrm{H}_{2} \mathrm{O}\left(\mathbf{2} \cdot 0.5 \mathrm{H}_{2} \mathrm{O}\right)$, and the $\pi^{*}$ of the solvent used. 


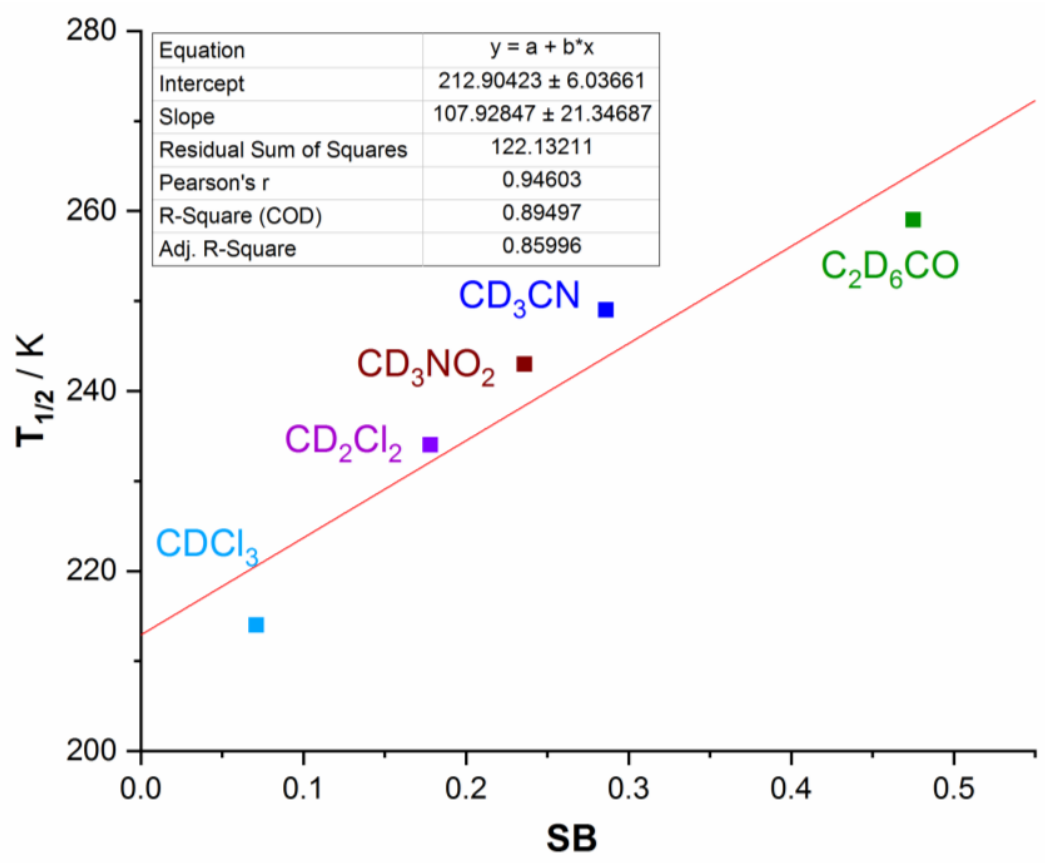

Figure S29. Plot showing the good correlation $\left(R^{2}=0.90\right)$ between solution $T_{1 / 2}$ values for the salt, $\left[\mathrm{Fe}^{\prime \prime}\left(\mathrm{L}^{45 \mathrm{Im}}\right)_{3}\right]\left(\mathrm{BF}_{4}\right)_{2} \cdot 0.5 \mathrm{H}_{2} \mathrm{O}\left(\mathbf{2} \cdot 0.5 \mathrm{H}_{2} \mathrm{O}\right)$, and Catalan and co-workers' Solvent Basicity (SB) of the solvent used.

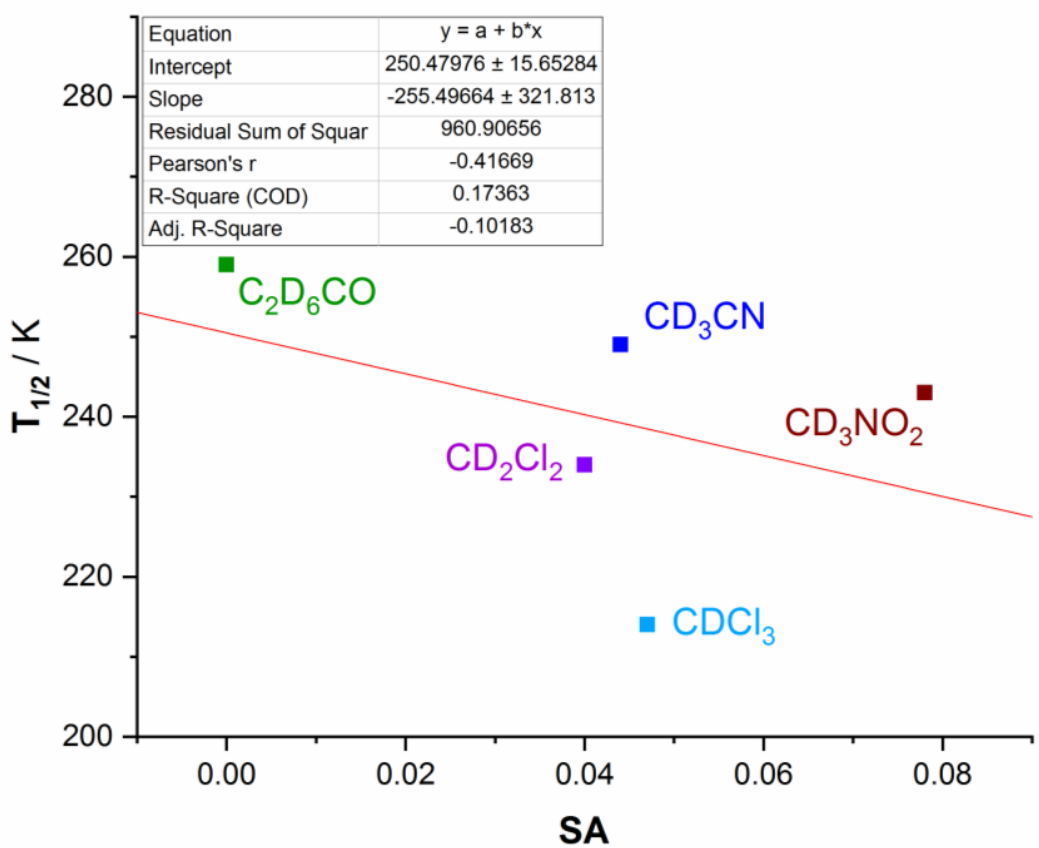

Figure S30. Plot showing the lack of correlation $\left(R^{2}=0.17\right)$ between solution $T_{1 / 2}$ values for the salt, $\left[\mathrm{Fe}^{\prime \prime}\left(\mathrm{L}^{4 \mathrm{SIm}}\right)_{3}\right]\left(\mathrm{BF}_{4}\right)_{2} \cdot 0.5 \mathrm{H}_{2} \mathrm{O}\left(2 \cdot 0.5 \mathrm{H}_{2} \mathrm{O}\right)$, and the Solvent Acidity $(\mathrm{SA})$ of the solvent used. 


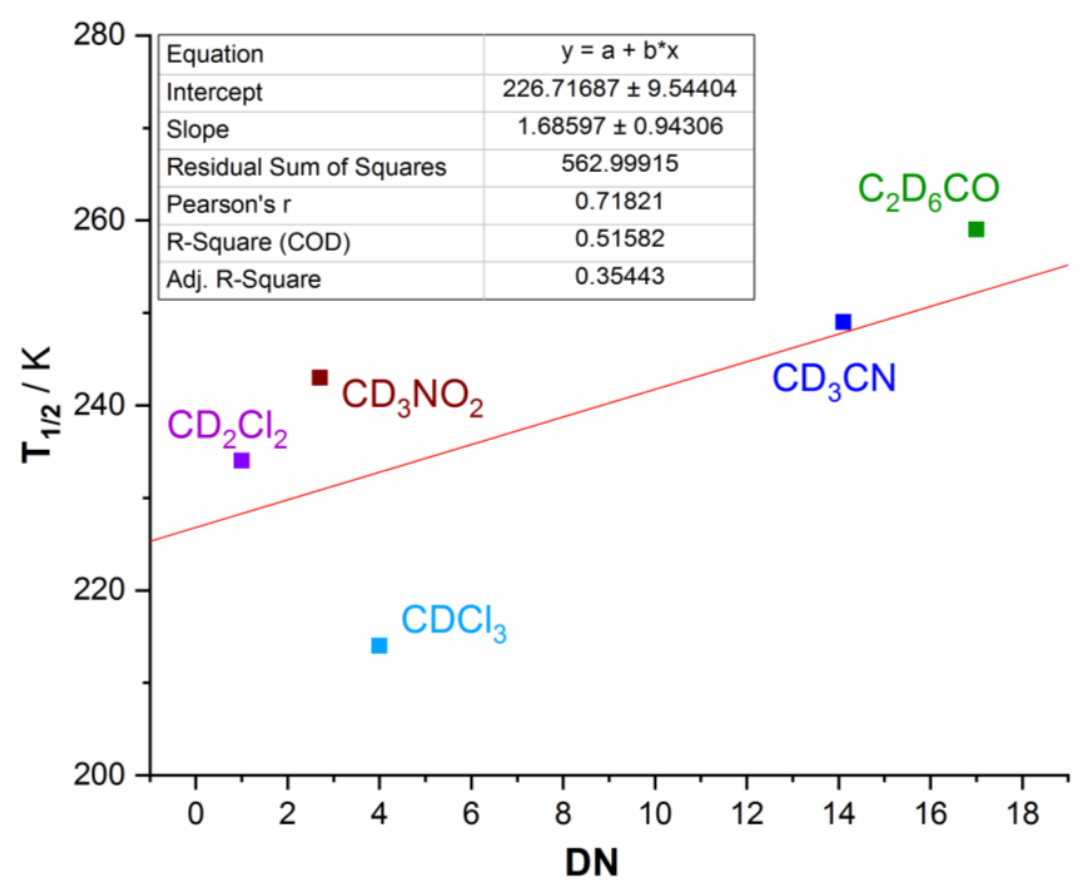

Figure S31. Plot showing the lack of correlation $\left(R^{2}=0.51\right)$ between solution $T_{1 / 2}$ values for the salt, $\left[\mathrm{Fe}^{\prime \prime}\left(\mathrm{L}^{4 \mathrm{sim}}\right)_{3}\right]\left(\mathrm{BF}_{4}\right)_{2} \cdot 0.5 \mathrm{H}_{2} \mathrm{O}\left(\mathbf{2} \cdot 0.5 \mathrm{H}_{2} \mathrm{O}\right)$, and the Gutmann's Donor Number (DN) of the solvent used.

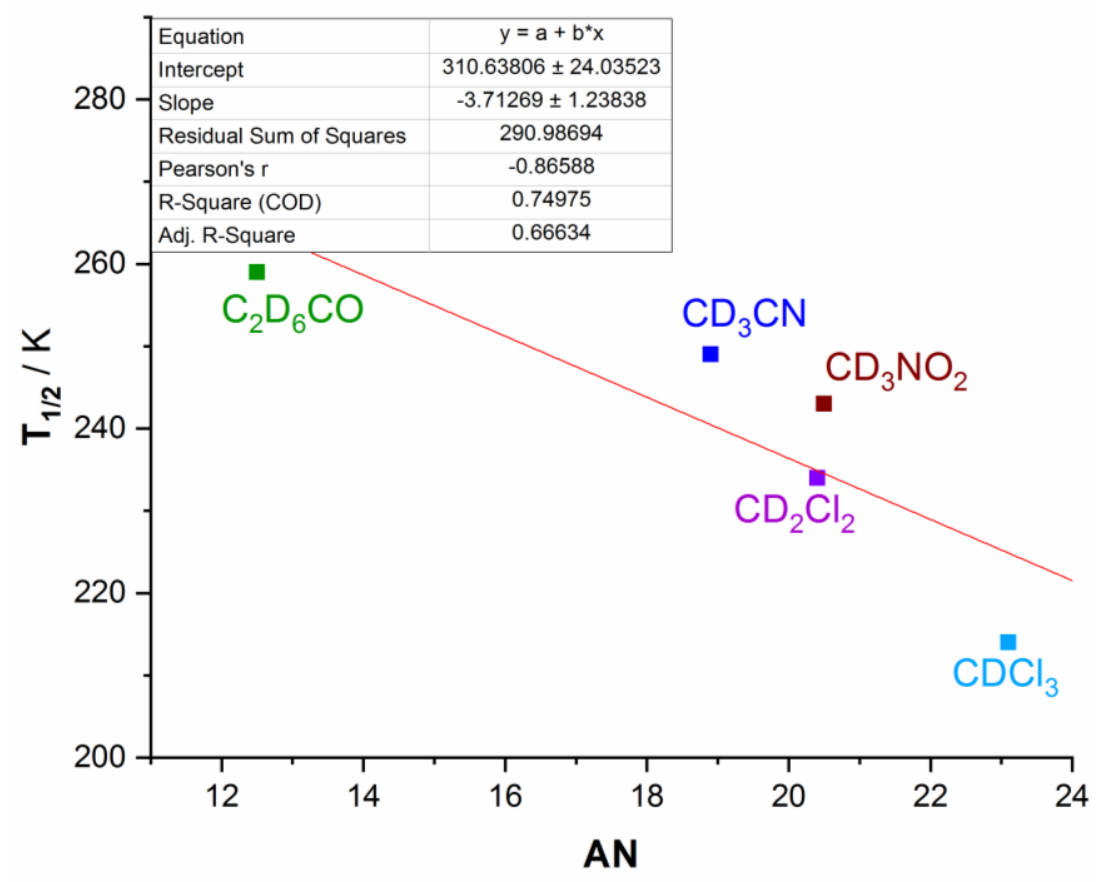

Figure S32. Plot showing the weak correlation $\left(R^{2}=0.75\right)$ between solution $T_{1 / 2}$ values for the salt, $\left[\mathrm{Fe}^{\prime \prime}\left(\mathrm{L}^{4 \mathrm{SIm}}\right)_{3}\right]\left(\mathrm{BF}_{4}\right)_{2} \cdot 0.5 \mathrm{H}_{2} \mathrm{O}\left(\mathbf{2} \cdot 0.5 \mathrm{H}_{2} \mathrm{O}\right)$, and the Mayer and Gutmann' Acceptor Number (AN) of the solvent used. 


\section{Solution state UV-vis spectroscopy}

The UV-vis spectra recorded from $253 \mathrm{~K}$ to $303 \mathrm{~K}$ on a golden yellow $4.8 \mathrm{mM}$ acetonitrile solution of $2 \cdot 0.5 \mathrm{H}_{2} \mathrm{O}$ (Figure S7). The resulting solution state VT-UV-vis data were then modelled using the regular solution model (Equation S3). The $\mathrm{R}^{2}$ for the fit is 0.97 , and this gave $\Delta H=18 \mathrm{~kJ} \cdot \mathrm{mol}^{-1}$ and $\Delta S=73$ $\mathrm{J} \cdot \mathrm{mol}^{-1} \cdot \mathrm{K}^{-1}$. The calculated $\mathrm{T}_{1 / 2}(=\Delta H / \Delta S)$ is $245 \mathrm{~K}$.

The increasing absorbance at $530 \mathrm{~nm}$ with decreasing temperature directly relates to the increasing population of the Fe(II) LS state. If HS and LS fraction are in thermal equilibrium, the absorbance can be defined as a function of temperature as equation $S 2^{16,17}$

$A(T)=\frac{A(0)}{1+e^{\left(\frac{(-\Delta H}{R T}+\frac{\Delta S}{R}\right)}} \quad$ Equation S2

According to the Beer-Lambert law, $\mathrm{A}=\varepsilon \mathrm{cl}$, so equation $\mathrm{S} 2$ can be rewritten as follows, in the terms of molar extinction coefficient:

$\varepsilon(T)=\frac{\varepsilon(0)}{1+e^{\left(\frac{-\Delta H}{R T}+\frac{\Delta S}{R}\right)}} \quad$ Equation S3

$\varepsilon(T)$ is molar extinction coefficient as function of temperature,

$\varepsilon(0)$ is the extinction coefficient for fully LS (i.e. $\gamma_{H S}=0$ ), estimated from the equation for the fit shown in Figure S34, $\gamma_{\mathrm{HS}}=-0.0047 \varepsilon+0.93$, to be $\varepsilon(0)=198 \mathrm{~L} \mathrm{~mol}^{-1} \mathrm{~cm}^{-1}$ (a significant extrapolation). For all fits to equation $\mathrm{S} 3, \varepsilon(0)$ was set to this value (198).

$R$ is the ideal gas constant $\left(8.314472 \mathrm{~J} \mathrm{~mol}^{-1} \mathrm{~K}^{-1}\right)$,

and the determined parameters, $\Delta \mathrm{H}$ and $\Delta \mathrm{S}$, are the thermodynamic enthalpy and entropy values associated with the SCO.

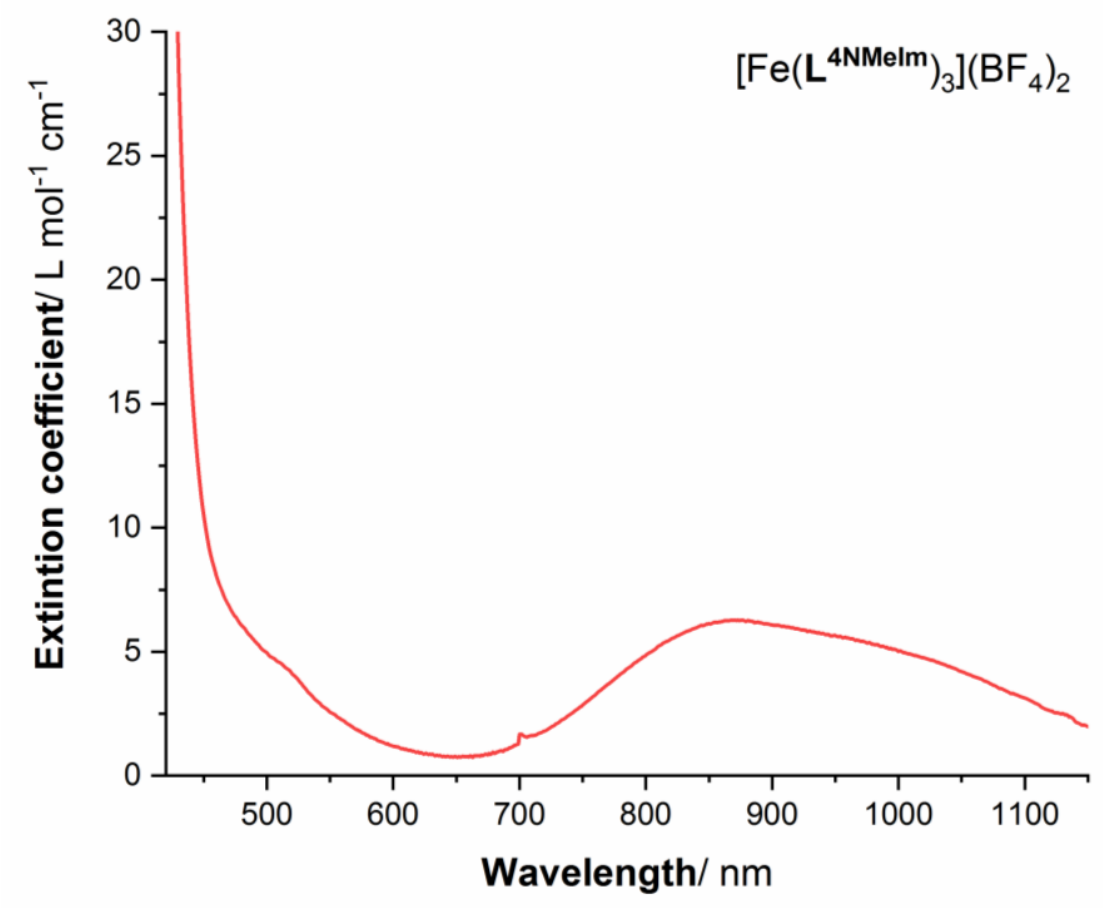

Figure S33. UV-vis study of $7.1 \mathrm{mM}$ acetonitrile solution of complex $1.4 \mathrm{H}_{2} \mathrm{O}$ at room temperature; $\lambda_{\text {max. }}=870 \mathrm{~nm}\left(\varepsilon=6 \mathrm{~L} \mathrm{~mol}^{-1} \mathrm{~cm}^{-1}\right)$ at room temperature. 
$\gamma_{H S}$ from the Evans method data (Table S14, $3^{\text {rd }}$ column) was calculated assuming $\chi_{m} T_{(H H)}=3.7 \mathrm{~K} \mathrm{~cm}^{3}$ $\mathrm{mol}^{-1}$ for the fully [HS-HS] state and $\chi_{\mathrm{m}} \mathrm{T}_{(\mathrm{LL})}=0 \mathrm{~K} \mathrm{~cm}^{3} \mathrm{~mol}^{-1}$ for the fully [LS-LS] state.

The ${ }^{1} \mathrm{H}-\mathrm{NMR}$ and UV-vis spectra were both recorded at $253 \mathrm{~K}, 263 \mathrm{~K}, 273 \mathrm{~K}, 283 \mathrm{~K}, 293 \mathrm{~K}$ and $303 \mathrm{~K}$ for 2.0.5 $\mathrm{H}_{2} \mathrm{O}$ in acetonitrile, so the extinction coefficient $(\varepsilon)$ values observed for the $530 \mathrm{~nm}$ band due to the LS state can be compared with the $\gamma_{\text {HS }}$ obtained by ${ }^{1} \mathrm{H}$-NMR Evans method at the same temperature. A plot of $\gamma_{\text {HS }}$ versus $\varepsilon$ (both per metal ion of the complex) gave the linear relationship noted in the insert (Figure S34), which was then used to convert each $\varepsilon$ (per metal ion of the complex) measured in UV-vis spectrum to a $\gamma_{H S}$ value (last column in Table S14), and to estimate the $\varepsilon(0)$ expected for the fully LS state (i.e. $\gamma_{\mathrm{HS}}=0$ ), to be $\varepsilon(0)=198 \mathrm{~L} \mathrm{~mol}^{-1} \mathrm{~cm}^{-1}$ (a significant extrapolation).

Table S14. Data obtained on $\mathbf{2} \cdot 0.5 \mathrm{H}_{2} \mathrm{O}$ in acetonitrile solution at various temperatures using two different methods: the Evans method VT- ${ }^{1} \mathrm{H}$ NMR gave $\chi_{m} T$ (per metal ion) and the UV-vis spectrum gave $\varepsilon$ (per metal ion) values for the band $530 \mathrm{~nm}$. Please see the above description (and Figure S35) of how these data were converted to the corresponding $\gamma_{\text {HS }}$ values.

$\gamma_{H S}\left(\right.$ based on $\left.\chi_{m} T\right)=$ the Evans method $\chi_{m} T$ value divided by $\chi_{m} T_{(H H)}=3.7 \mathrm{~K} \mathrm{~cm}^{3} \mathrm{~mol}^{-1}$.

$\gamma_{\text {HS }}($ based on $\varepsilon)=-0.0047 \varepsilon+0.93$ (Figure S34); which converts the UV-vis study $\varepsilon$ value into $\gamma_{\text {HS }}$ (based on $\varepsilon$ ).

\begin{tabular}{|l|l|l|l|l|}
\hline Temperature (K) & $\begin{array}{l}\chi_{\mathrm{m}} \mathbf{T} \\
\text { (per metal ion) }\end{array}$ & $\begin{array}{l}\gamma_{\mathrm{HS}} \\
\text { (based on } \chi_{\mathbf{m}} \mathbf{T} \text { ) }\end{array}$ & $\begin{array}{l}\boldsymbol{\varepsilon} \\
\text { (per metal ion) }\end{array}$ & $\begin{array}{l}\gamma_{\mathrm{HS}} \\
\text { (based on } \boldsymbol{\varepsilon})\end{array}$ \\
\hline 243 & 1.65 & 0.45 & & \\
\hline 253 & 1.96 & 0.53 & 90 & 0.51 \\
\hline 263 & 2.24 & 0.61 & 67 & 0.62 \\
\hline 273 & 2.46 & 0.66 & 55 & 0.67 \\
\hline 283 & 2.66 & 0.72 & 45 & 0.72 \\
\hline 293 & 2.80 & 0.76 & 39 & 0.74 \\
\hline 303 & 2.92 & 0.79 & 34 & 0.77 \\
\hline 313 & 3.03 & 0.82 & & \\
\hline 323 & 3.10 & 0.84 & & \\
\hline 333 & 3.20 & 0.86 & & \\
\hline 343 & 3.27 & 0.88 & & \\
\hline
\end{tabular}




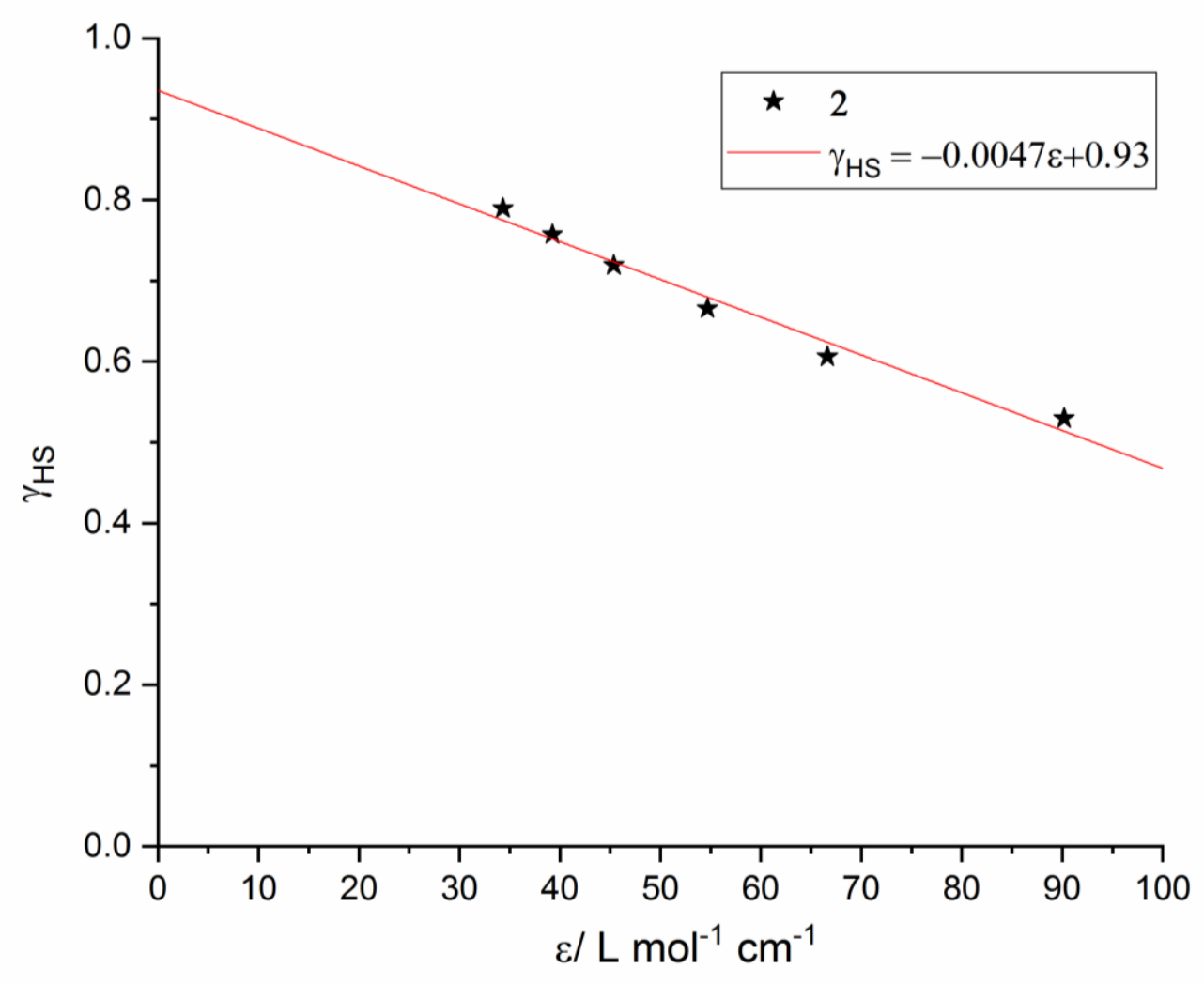

Figure S34. Plot of $\gamma_{H S}$ (obtained from Evans method, see above text for how $\chi_{m} T_{(H H)}$ was converted to this) vs extinction coefficient per metal ion (obtained from the variable temperature UV-vis studies) of the $530 \mathrm{~nm}$ band of complex $2 \cdot 0.5 \mathrm{H}_{2} \mathrm{O}$ (associated with the LS state) in $4.8 \mathrm{mM}$ acetonitrile solution. The linear fit equation $\left(y=m x+c\right.$, here $\left.\gamma_{H S}=-0.0047 \varepsilon+0.93\right)$ was then used to convert each $\varepsilon$ value into the respective $\gamma_{H S}(U V$-vis, see Table S14), and to estimate the $\varepsilon(0)$ expected for the fully LS state (i.e. $\gamma_{\mathrm{HS}}=0$ ), to be $\varepsilon(0)=198 \mathrm{~L} \mathrm{~mol}^{-1} \mathrm{~cm}^{-1}$. 


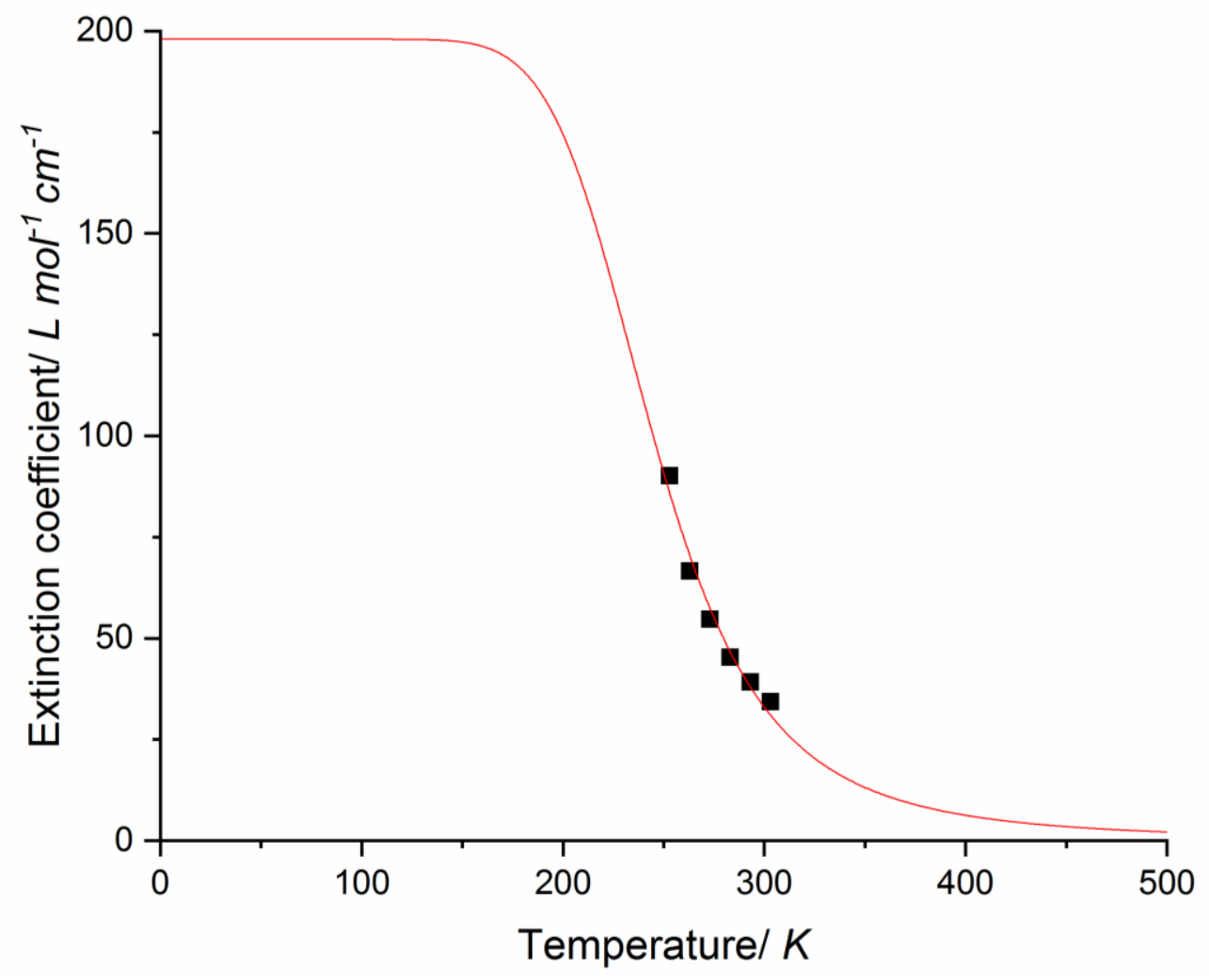

Figure S35. Temperature dependence of the molar extinction coefficients $(\varepsilon)$ of the $530 \mathrm{~nm} \mathrm{LS} \mathrm{Fe(II)}$ ${ }^{1} \mathrm{~A}_{1 \mathrm{~g}} \rightarrow{ }^{1} \mathrm{~T}_{1 \mathrm{~g}}$ band of $2 \cdot 0.5 \mathrm{H}_{2} \mathrm{O}$ in acetonitrile solution. Red curve represents fit to equation $\mathrm{S3}, \mathrm{R}^{2}=0.97$, having set $\varepsilon(0)=198 \mathrm{~L} \mathrm{~mol}^{-1} \mathrm{~cm}^{-1}$, see Figure S34). 


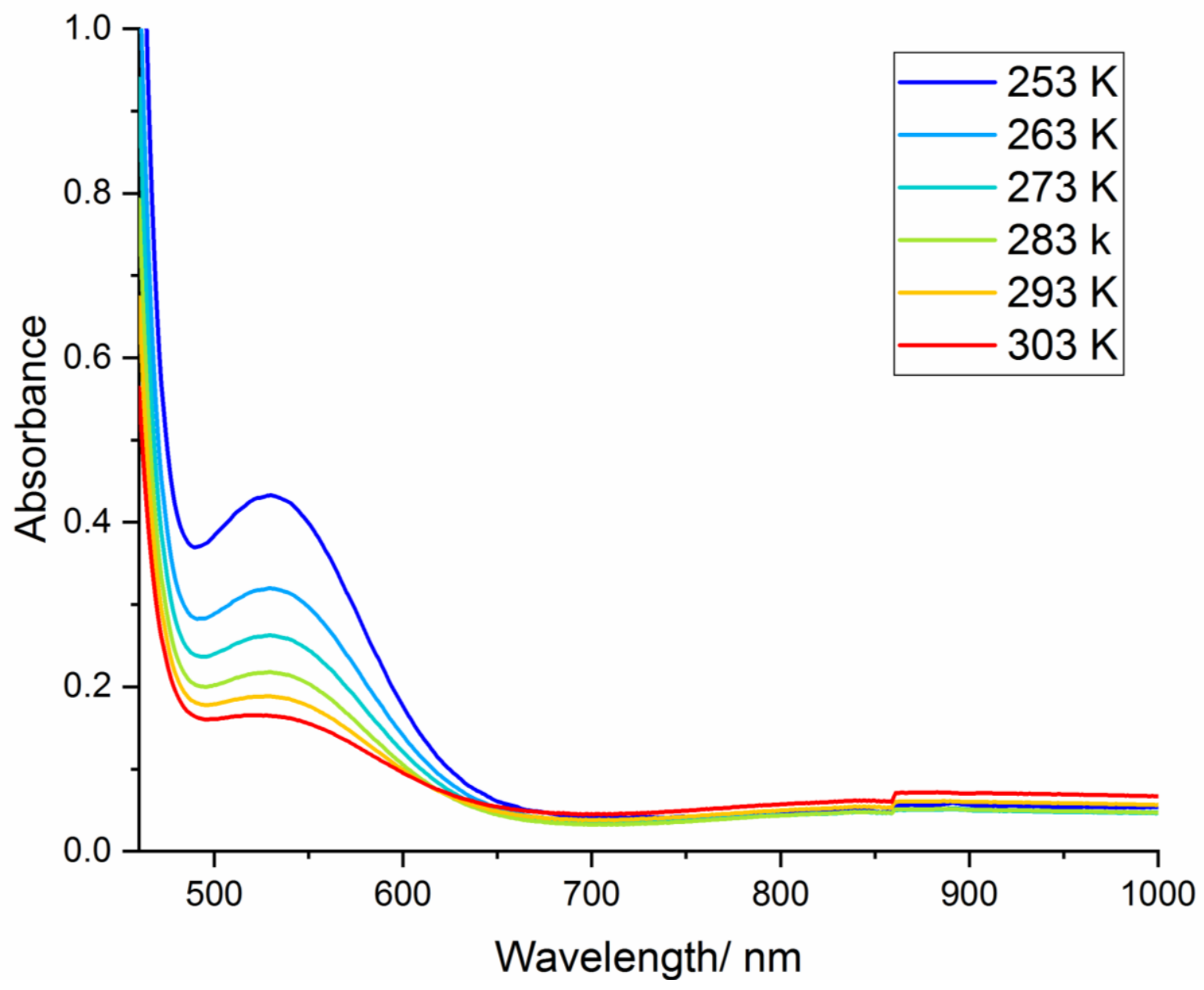

Figure S36. UV-vis studies of $4.8 \mathrm{mM}$ acetonitrile solution of complex $2 \cdot 0.5 \mathrm{H}_{2} \mathrm{O}$ with varying temperatures from $253 \mathrm{~K}$ to $303 \mathrm{~K}$, absorbance vs wavelength (extinction coefficient plot in main body of the paper). 


\section{Cyclic voltammetry}

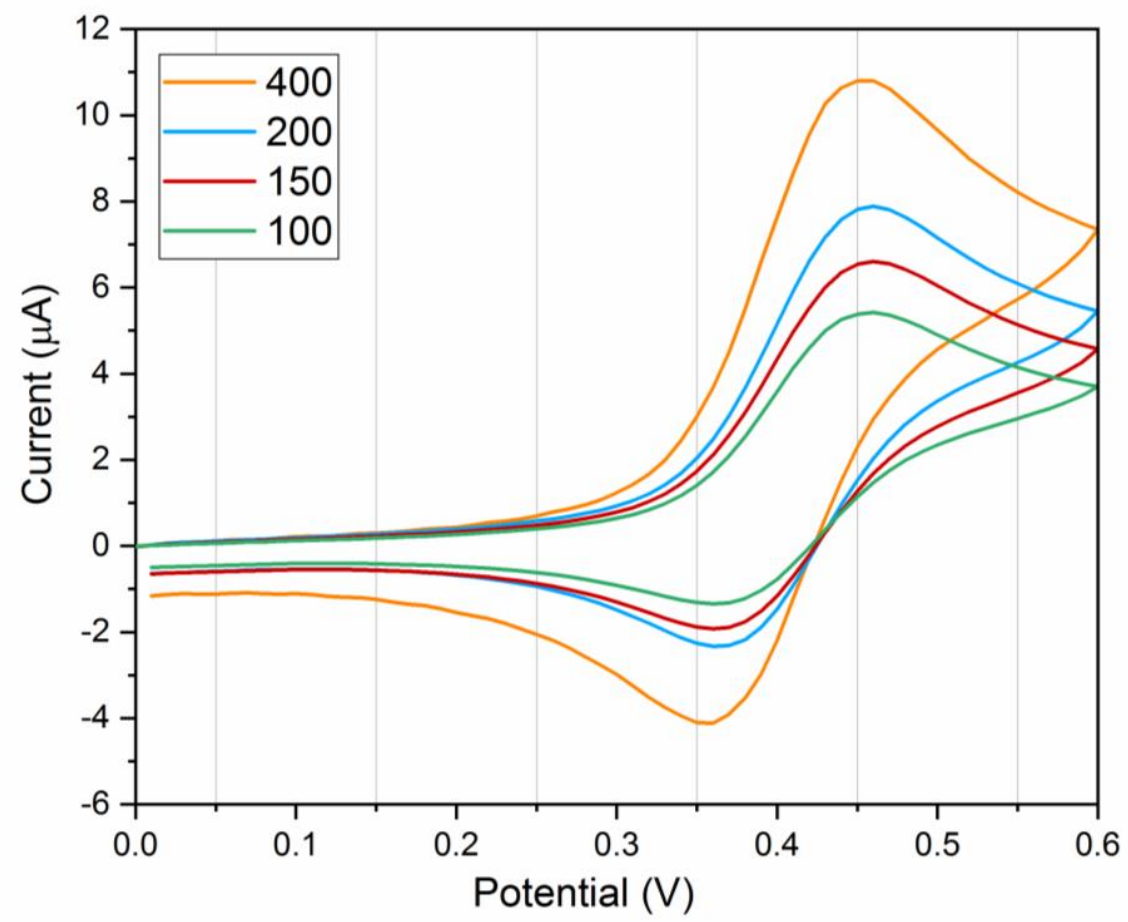

Figure S37. CVs of $1 \mathrm{mM}$ of $\left[\mathrm{Fe}\left(\mathrm{L}^{4 \mathrm{NMelm}}\right)_{3}\right]\left(\mathrm{BF}_{4}\right)_{2}\left(1 \cdot 4 \mathrm{H}_{2} \mathrm{O}\right)$ in $\mathrm{MeCN}$, from $0 \rightarrow+0.6 \rightarrow 0 \mathrm{~V}$ vs $0.01 \mathrm{M}$ $\mathrm{Ag} / \mathrm{AgNO}_{3}$ at scan rates 100, 150, 200 and $400 \mathrm{mV} \mathrm{s}^{-1}$. Working electrode: Pt (1.6 mm diameter).

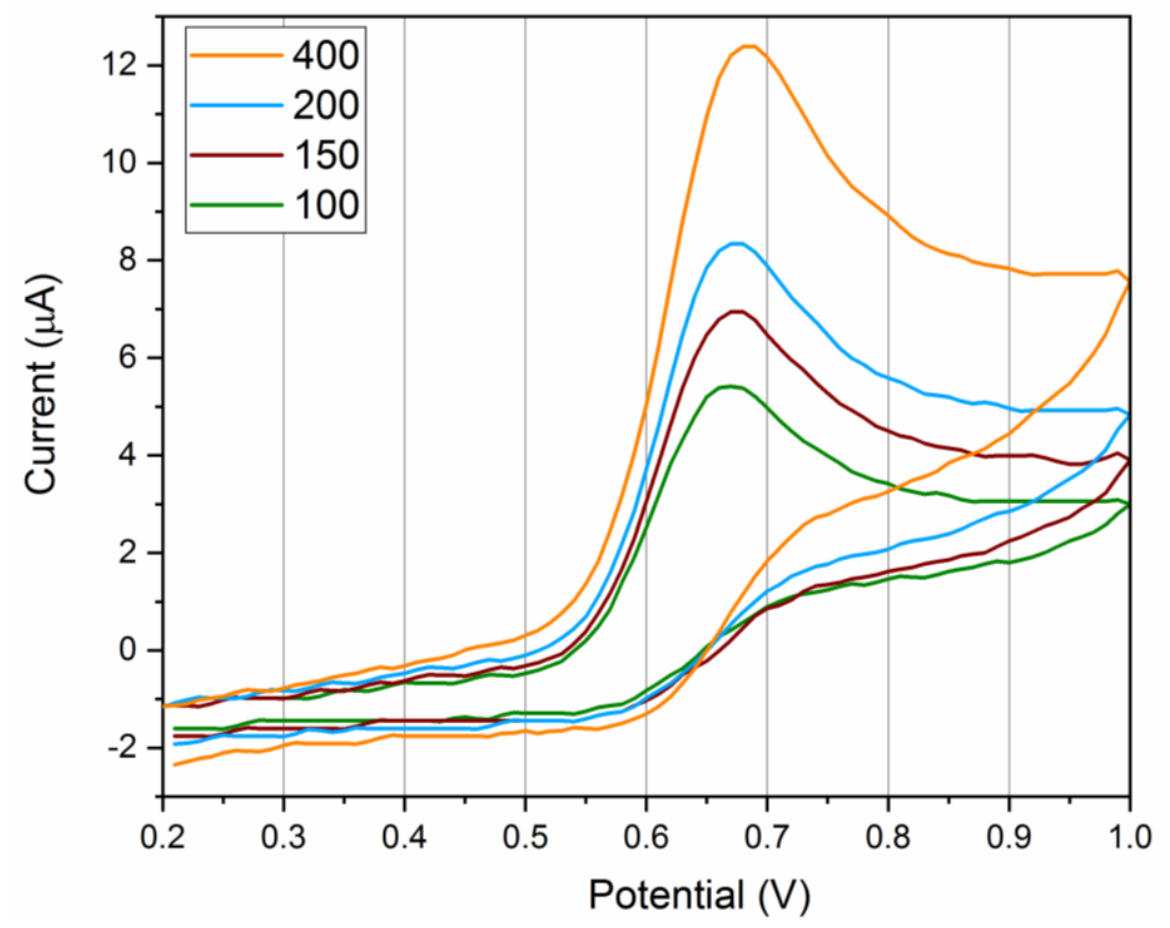

Figure S38. CVs of $1 \mathrm{mM}$ of $\left[\mathrm{Fe}\left(\mathrm{L}^{4 \mathrm{SIm}}\right)_{3}\right]\left(\mathrm{BF}_{4}\right)_{2}\left(2 \cdot 0.5 \mathrm{H}_{2} \mathrm{O}\right)$ in $\mathrm{MeCN}$, from $0.2 \rightarrow 1.0 \rightarrow 0.2 \mathrm{~V}$ vs $0.01 \mathrm{M}$ $\mathrm{Ag} / \mathrm{AgNO}_{3}$ at scan rates 100, 150, 200 and $400 \mathrm{mV} \mathrm{s}^{-1}$. Working electrode: Pt (1.6 mm diameter). 


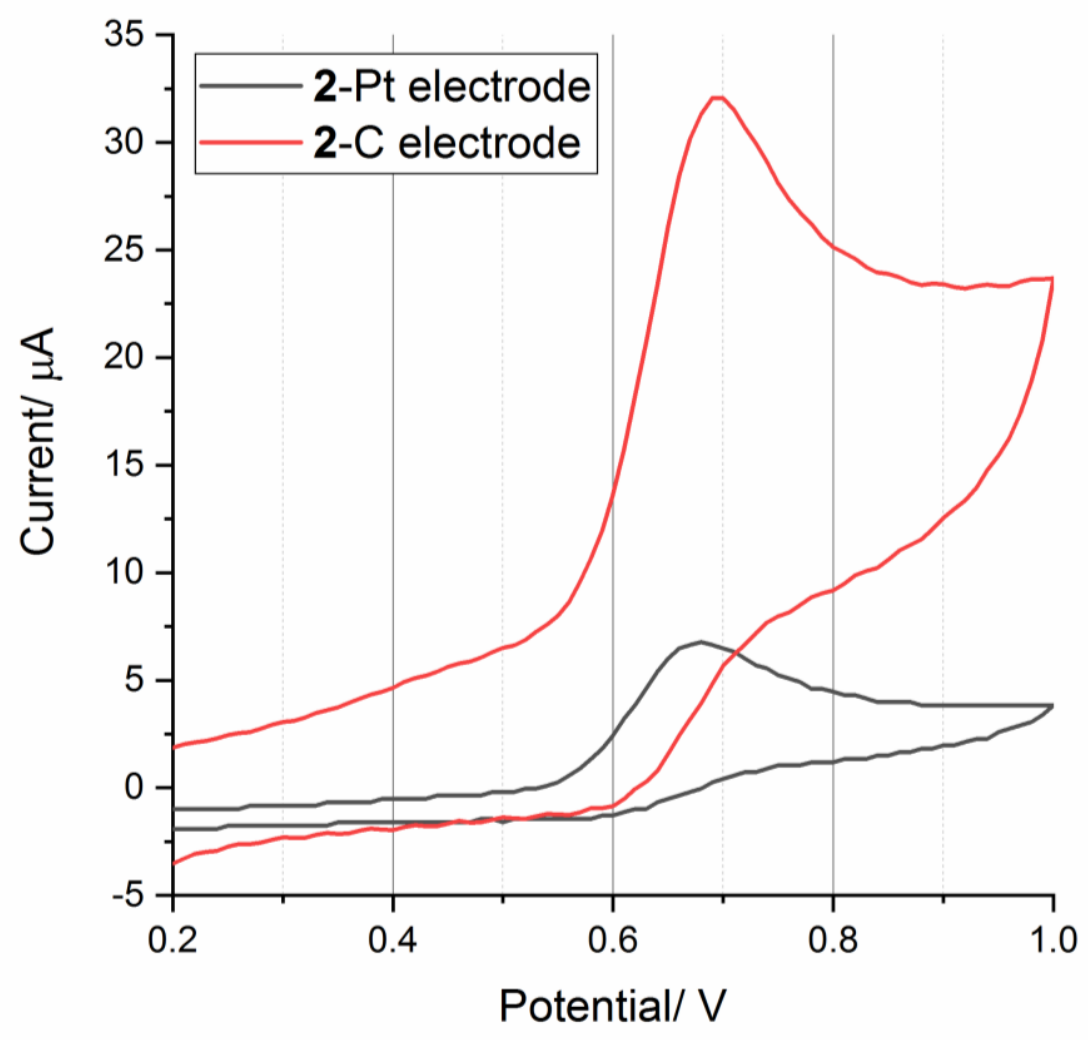

Figure S39. CVs of $1 \mathrm{mM}$ of $\left[\mathrm{Fe}\left(\mathrm{L}^{4 \mathrm{SIm}}\right)_{3}\right]\left(\mathrm{BF}_{4}\right)_{2}\left(2 \cdot 0.5 \mathrm{H}_{2} \mathrm{O}\right)$ in $\mathrm{MeCN}$, from $0.2 \rightarrow 1.0 \rightarrow 0.2 \mathrm{~V}$ vs $0.01 \mathrm{M}$ $\mathrm{Ag} / \mathrm{AgNO}_{3}$ at scan rate $200 \mathrm{mV} \mathrm{s}$. Working electrode: black trace Pt $\left(1.6 \mathrm{~mm}\right.$ diameter; $2.01 \mathrm{~mm}^{2}$ surface area); red trace glassy carbon ( $3 \mathrm{~mm}$ diameter; if consider it flat then $7.07 \mathrm{~mm}^{2}$ surface area, but it is greater than this as it is a rough surface). Note: the observed $5 x$ increase in the maximum current on going from $\mathrm{Pt}$ to glassy carbon simply reflects the more than $3.5 \mathrm{x}$ increase in the surface area. 


\section{Mass spectra}

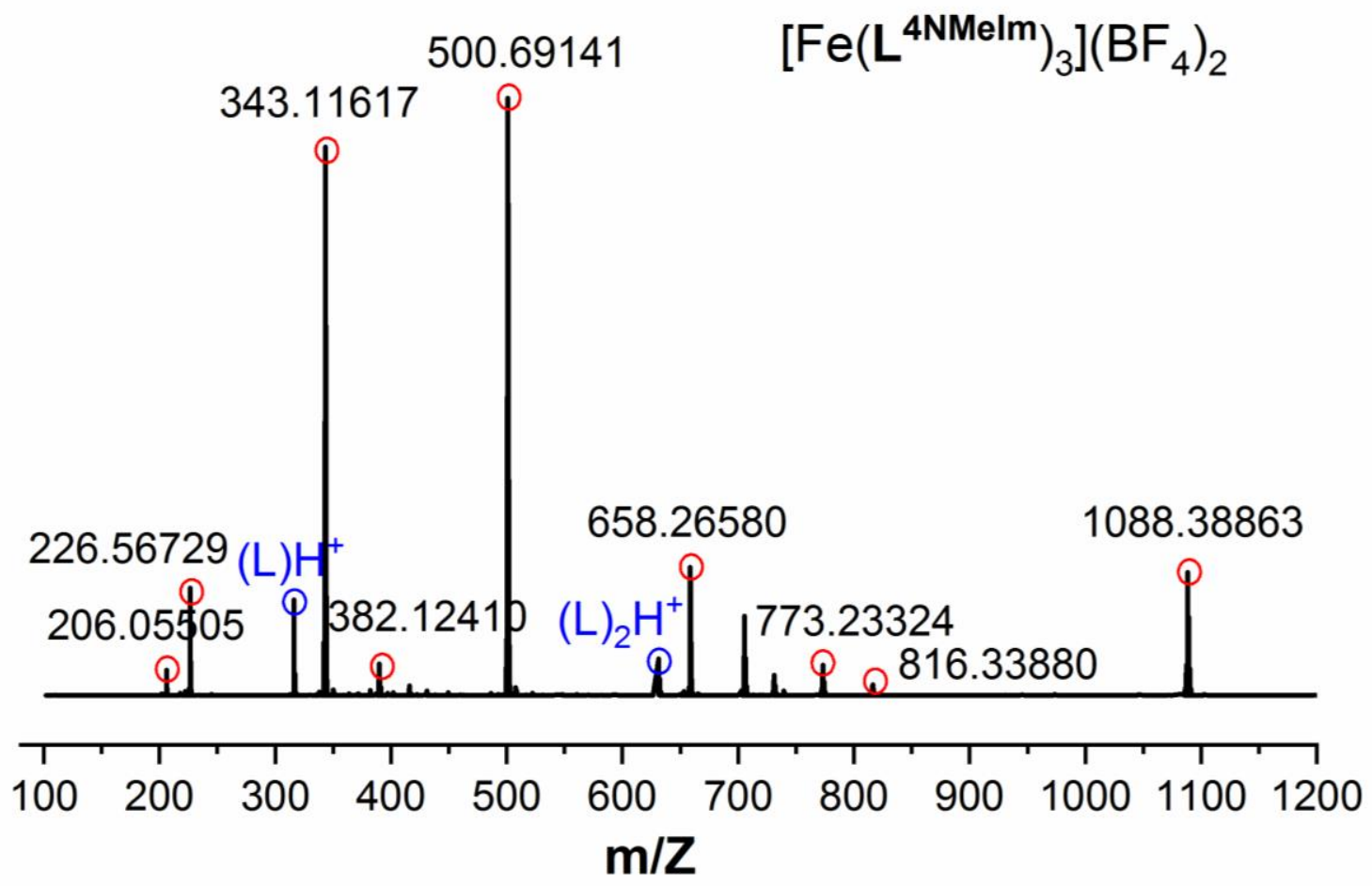

Figure S40. Mass spectrum of $\left[\mathrm{Fe}\left(\mathrm{L}^{4 \mathrm{NMelm}}\right)_{3}\right]\left(\mathrm{BF}_{4}\right)_{2}(\mathbf{1})$. Fits of the circled peaks are provided in the following figures.

$\left[\mathrm{Fe}\left(\mathrm{C}_{19} \mathrm{H}_{17} \mathrm{~N}_{5}\right)_{1}\left(\mathrm{CH}_{3} \mathrm{CN}\right)\right]^{2+}$

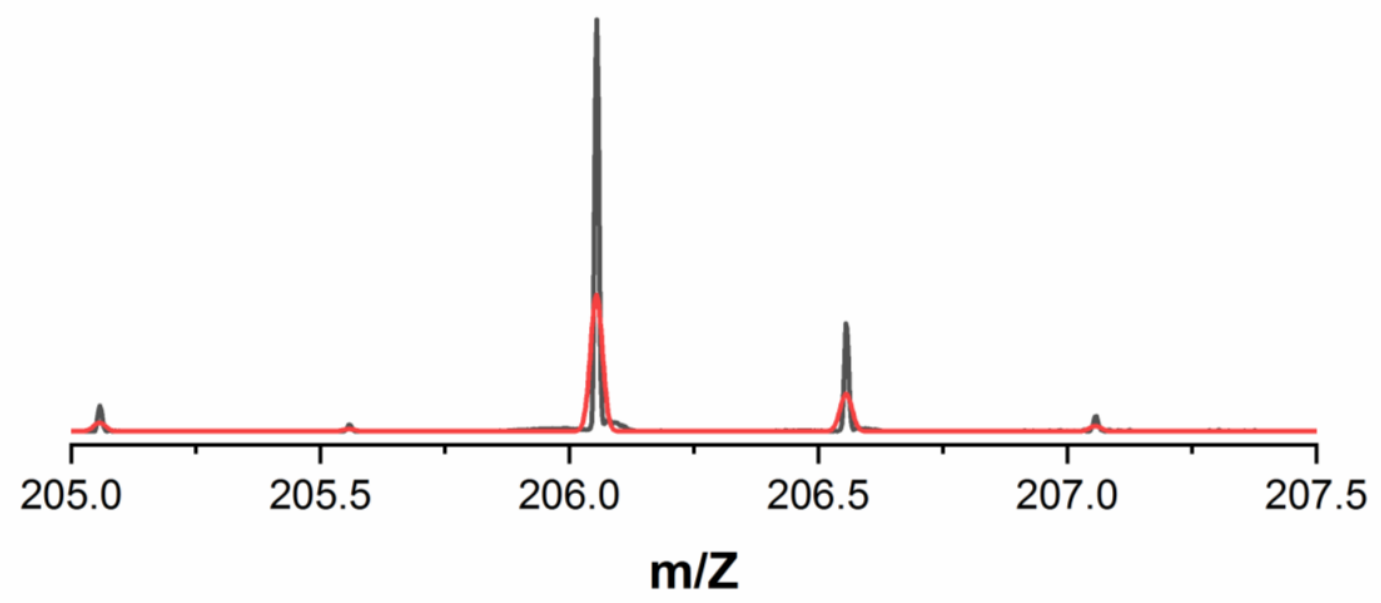

Figure S41. Fit of a peak in the mass spectrum of $\left[\mathrm{Fe}\left(\mathrm{L}^{4 \mathrm{NMelm}}\right)_{3}\right]\left(\mathrm{BF}_{4}\right)_{2}$ (1) (Figure S40): $\left[\mathrm{Fe}\left(\mathrm{L}^{\mathrm{LNMelm}}\right)_{1}\left(\mathrm{CH}_{3} \mathrm{CN}\right)\right]^{2+}$ experimental (black) and simulated pattern (red). 


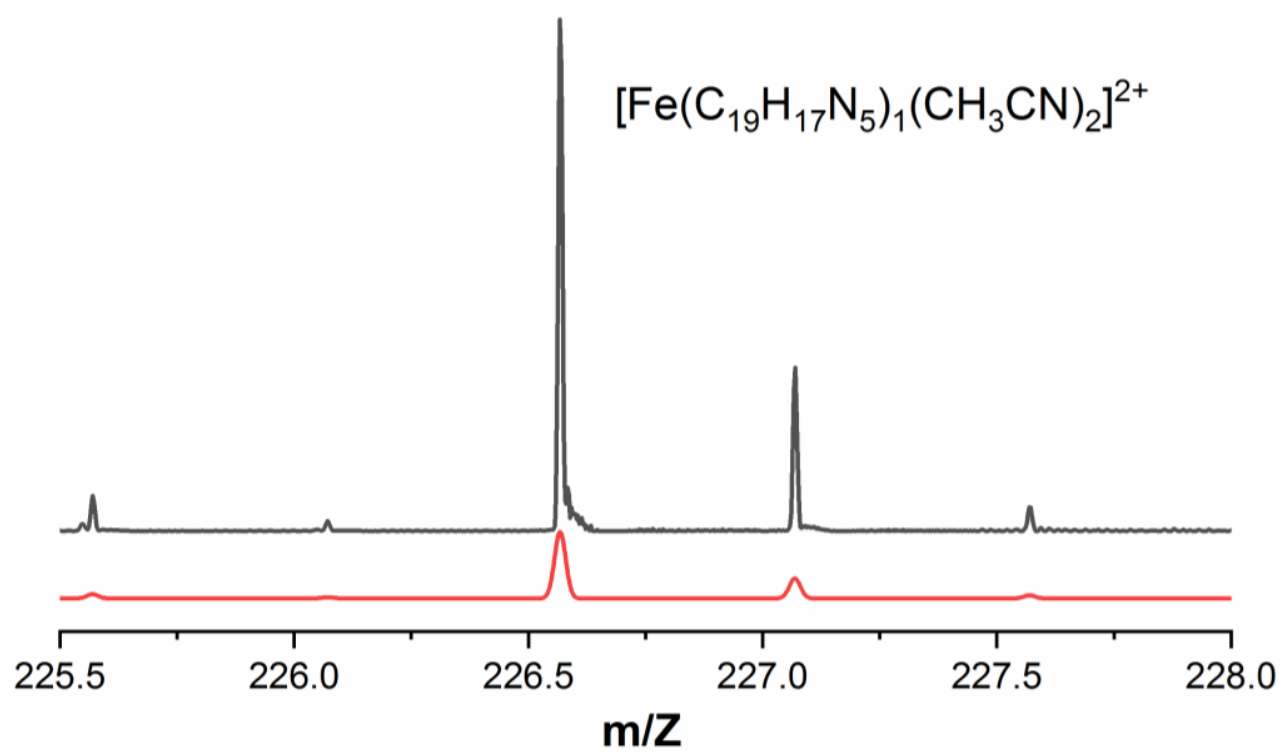

Figure S42. Fit of a peak in the mass spectrum of $\left[\mathrm{Fe}\left(\mathrm{L}^{4 \mathrm{NMelm}}\right)_{3}\right]\left(\mathrm{BF}_{4}\right)_{2}$ (1) (Figure S40): $\left[\mathrm{Fe}\left(\mathrm{L}^{\mathrm{4NMelm}}\right)_{1}\left(\mathrm{CH}_{3} \mathrm{CN}\right)_{2}\right]^{2+}$ experimental (black) and simulated pattern (red).

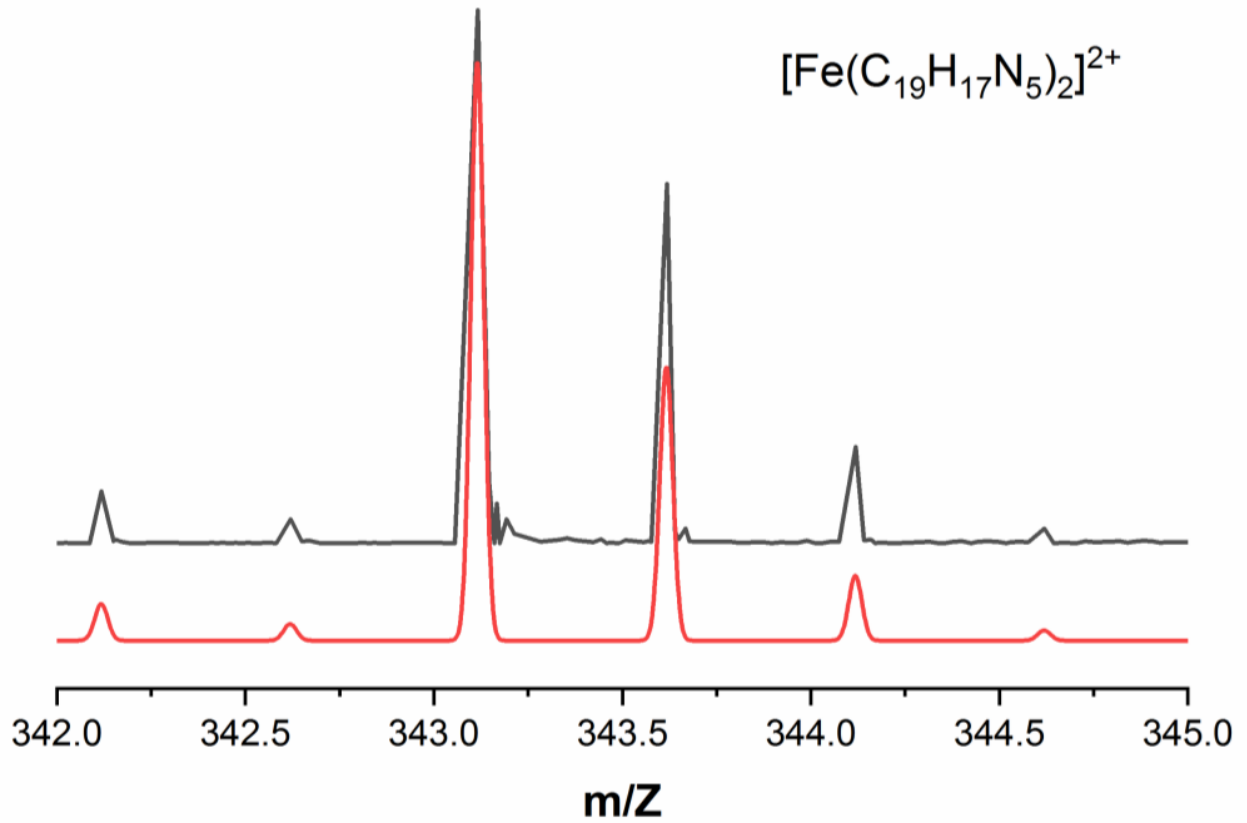

Figure S43. Fit of a peak in the mass spectrum of $\left[\mathrm{Fe}\left(\mathrm{L}^{4 \mathrm{NMelm}}\right)_{3}\right]\left(\mathrm{BF}_{4}\right)_{2}(\mathbf{1})\left(\right.$ Figure S40): $\left[\mathrm{Fe}\left(\mathrm{L}^{4 \mathrm{NMelm}}\right)_{2}\right]^{2+}$ experimental (black) and simulated pattern (red). 


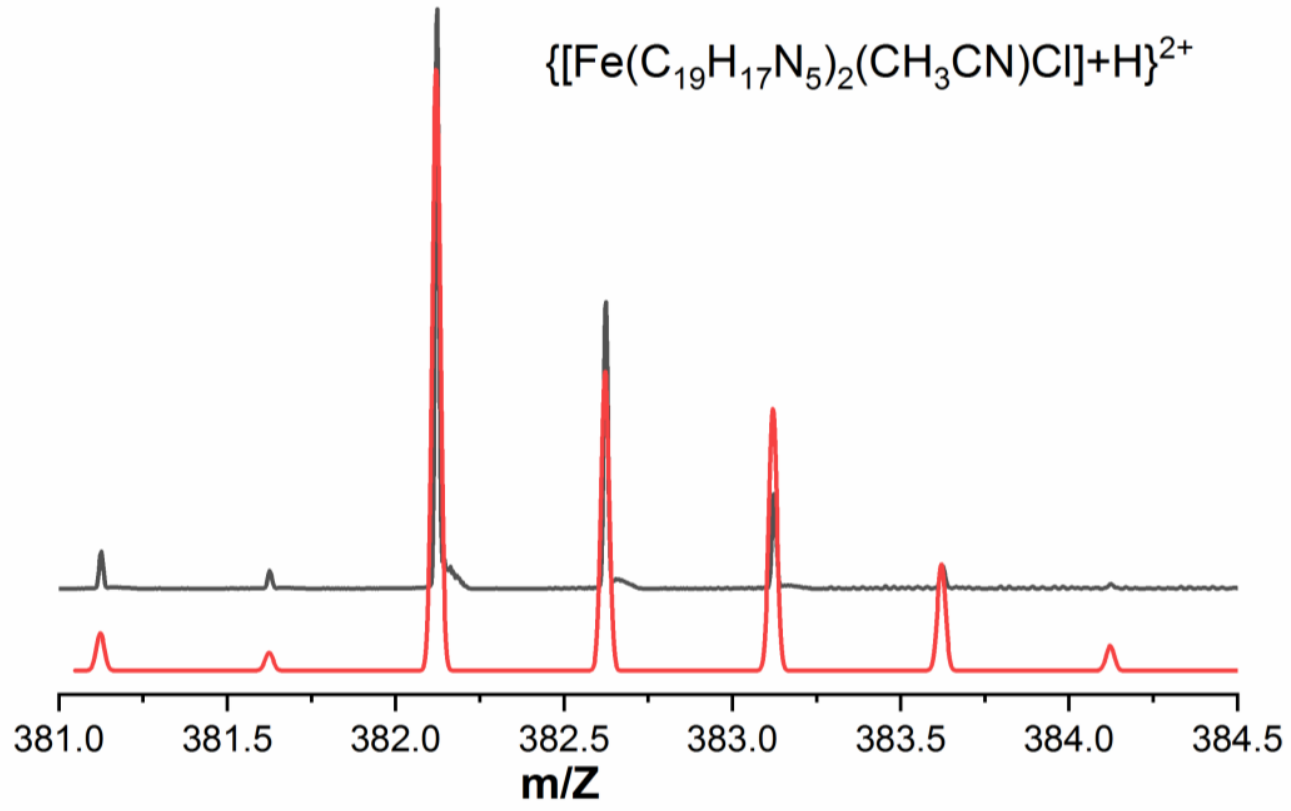

Figure S44. Fit of a peak in the mass spectrum of $\left[\mathrm{Fe}\left(\mathrm{L}^{4 \mathrm{NMelm}}\right)_{3}\right]\left(\mathrm{BF}_{4}\right)_{2}$ (1) (Figure $\mathrm{S} 40$ ): $\left(\left[\mathrm{Fe}\left(\mathrm{L}^{\mathrm{4NMelm}}\right)_{2}\left(\mathrm{CH}_{3} \mathrm{CN}\right) \mathrm{Cl}\right]+\mathrm{H}\right)^{2+}$ experimental (black) and simulated pattern (red).

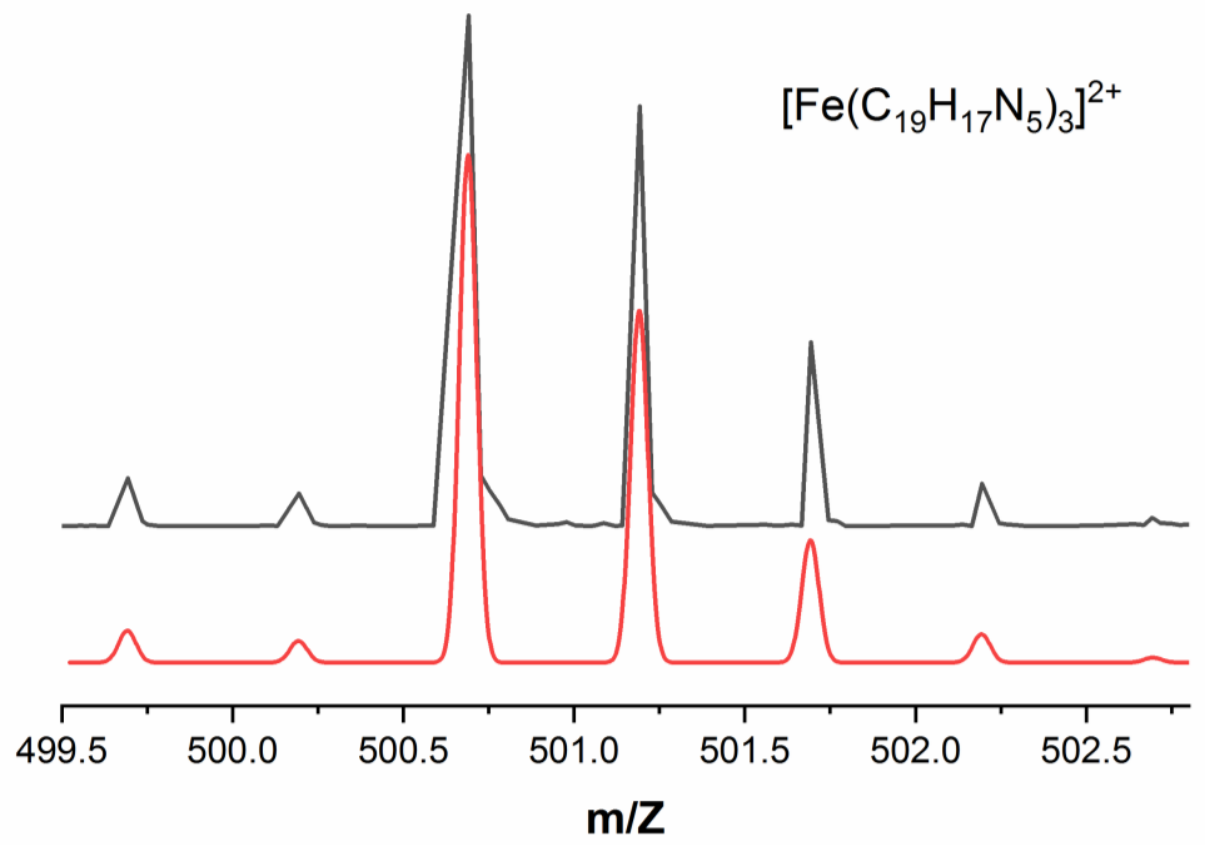

Figure S45. Fit of a peak in the mass spectrum of $\left[\mathrm{Fe}\left(\mathrm{L}^{4 \mathrm{NMelm}}\right)_{3}\right]\left(\mathrm{BF}_{4}\right)_{2}(\mathbf{1})$ (Figure S40): $\left[\mathrm{Fe}\left(\mathrm{L}^{4 \mathrm{NMelm}}\right)_{3}\right]^{2+}$ experimental (black) and simulated pattern (red). 


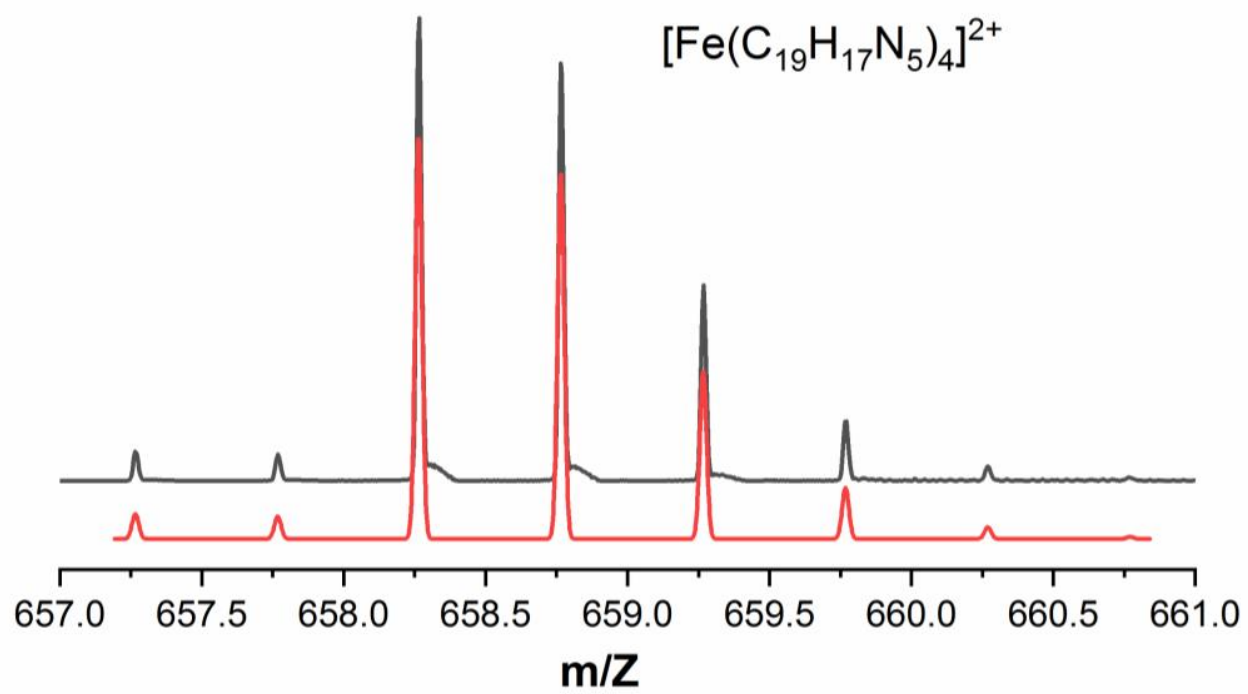

Figure S46. Fit of a peak in the mass spectrum of $\left[\mathrm{Fe}\left(\mathrm{L}^{4 \mathrm{NMelm}}\right)_{3}\right]\left(\mathrm{BF}_{4}\right)_{2}(\mathbf{1})($ Figure $\mathrm{S} 40):\left[\mathrm{Fe}\left(\mathrm{L}^{4 \mathrm{NMelm}}\right)_{4}\right]^{2+}$ experimental (black) and simulated pattern (red).

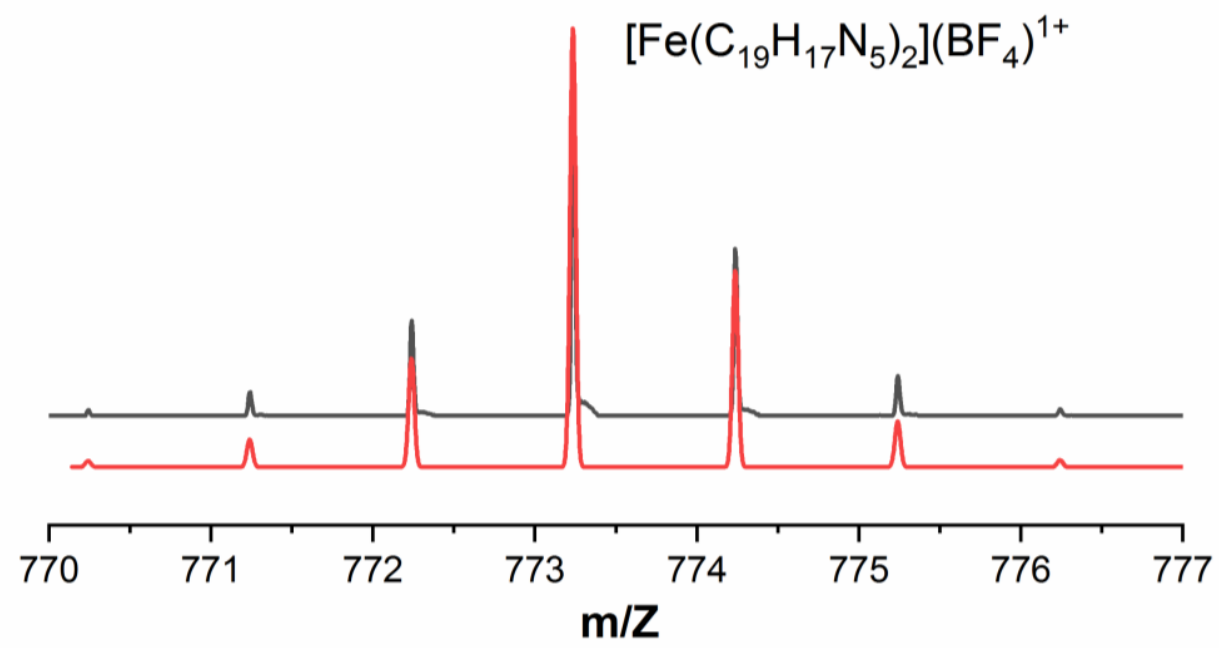

Figure S47. Fit of a peak in the mass spectrum of $\left[\mathrm{Fe}\left(\mathrm{L}^{4 \mathrm{NMelm}}\right)_{3}\right]\left(\mathrm{BF}_{4}\right)_{2}(\mathbf{1})$ (Figure S40): $\left[\mathrm{Fe}\left(\mathrm{L}^{4 \mathrm{NMelm}}\right)_{2}\right]$ $\left(\mathrm{BF}_{4}\right)^{1+}$ experimental (black) and simulated pattern (red). 


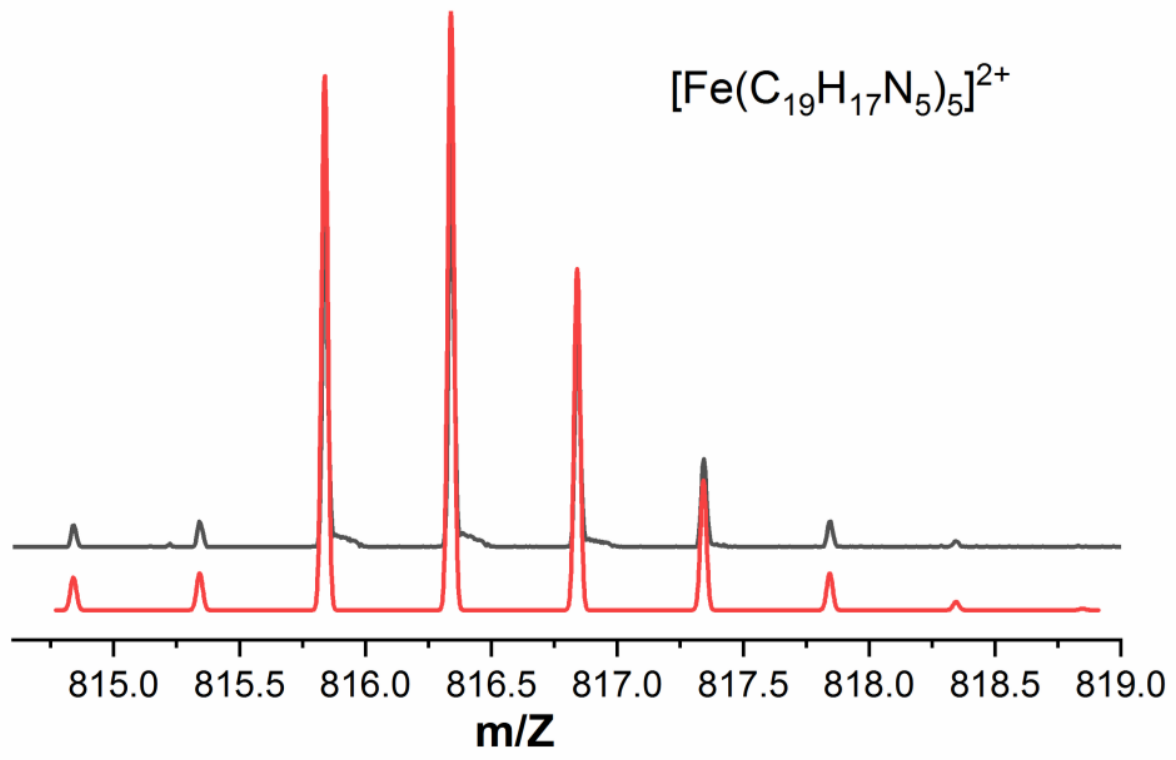

Figure S48. Fit of a peak in the mass spectrum of $\left[\mathrm{Fe}\left(\mathrm{L}^{4 \mathrm{NMelm}}\right)_{3}\right]\left(\mathrm{BF}_{4}\right)_{2}(\mathbf{1})($ Figure $\mathrm{S} 40)$ : $\left[\mathrm{Fe}\left(\mathrm{L}^{4 \mathrm{NMelm}}\right)_{5}\right]^{2+}$ experimental (black) and simulated pattern (red).

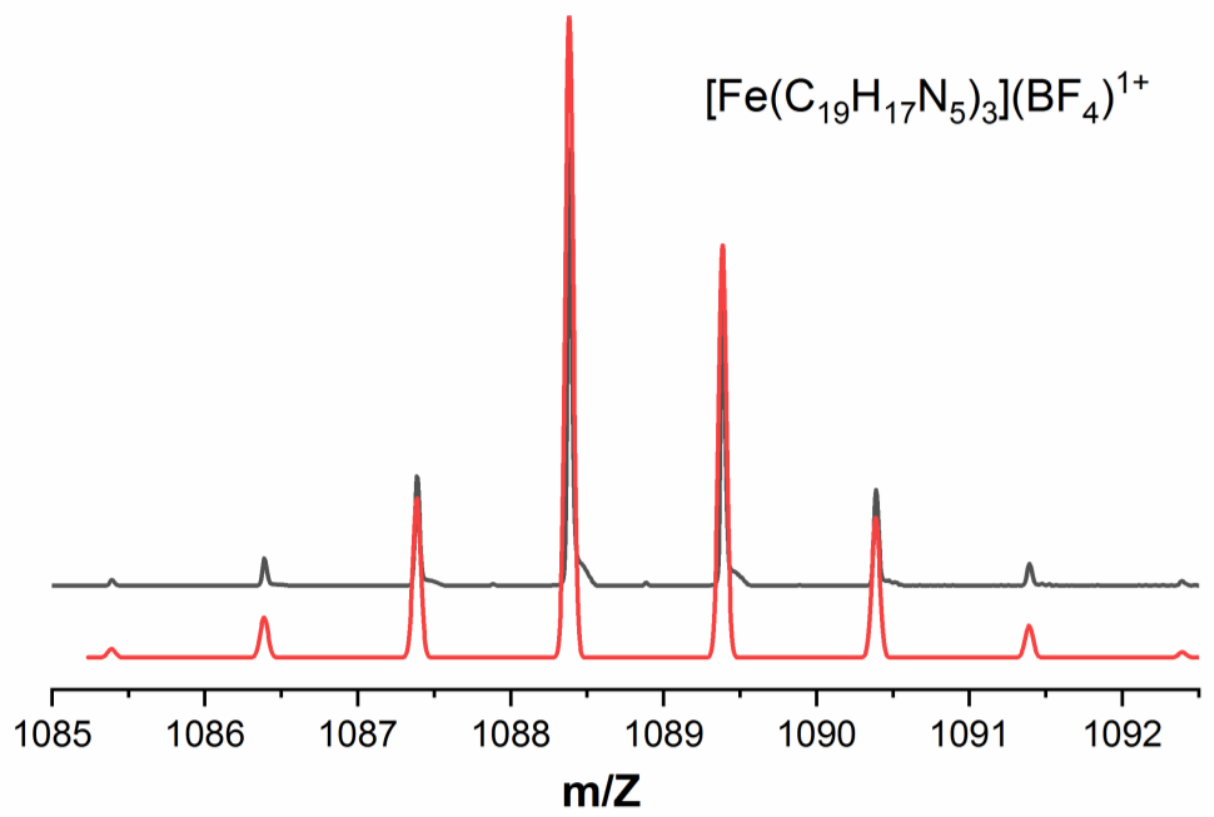

Figure S49. Fit of a peak in the mass spectrum of $\left[\mathrm{Fe}\left(\mathrm{L}^{\mathrm{4NMelm}}\right)_{3}\right]\left(\mathrm{BF}_{4}\right)_{2}(\mathbf{1})$ (Figure S40): $\left[\mathrm{Fe}\left(\mathrm{L}^{\mathrm{LNMelm}}\right)_{3}\right]$ $\left(\mathrm{BF}_{4}\right)^{1+}$ experimental (black) and simulated pattern (red). 


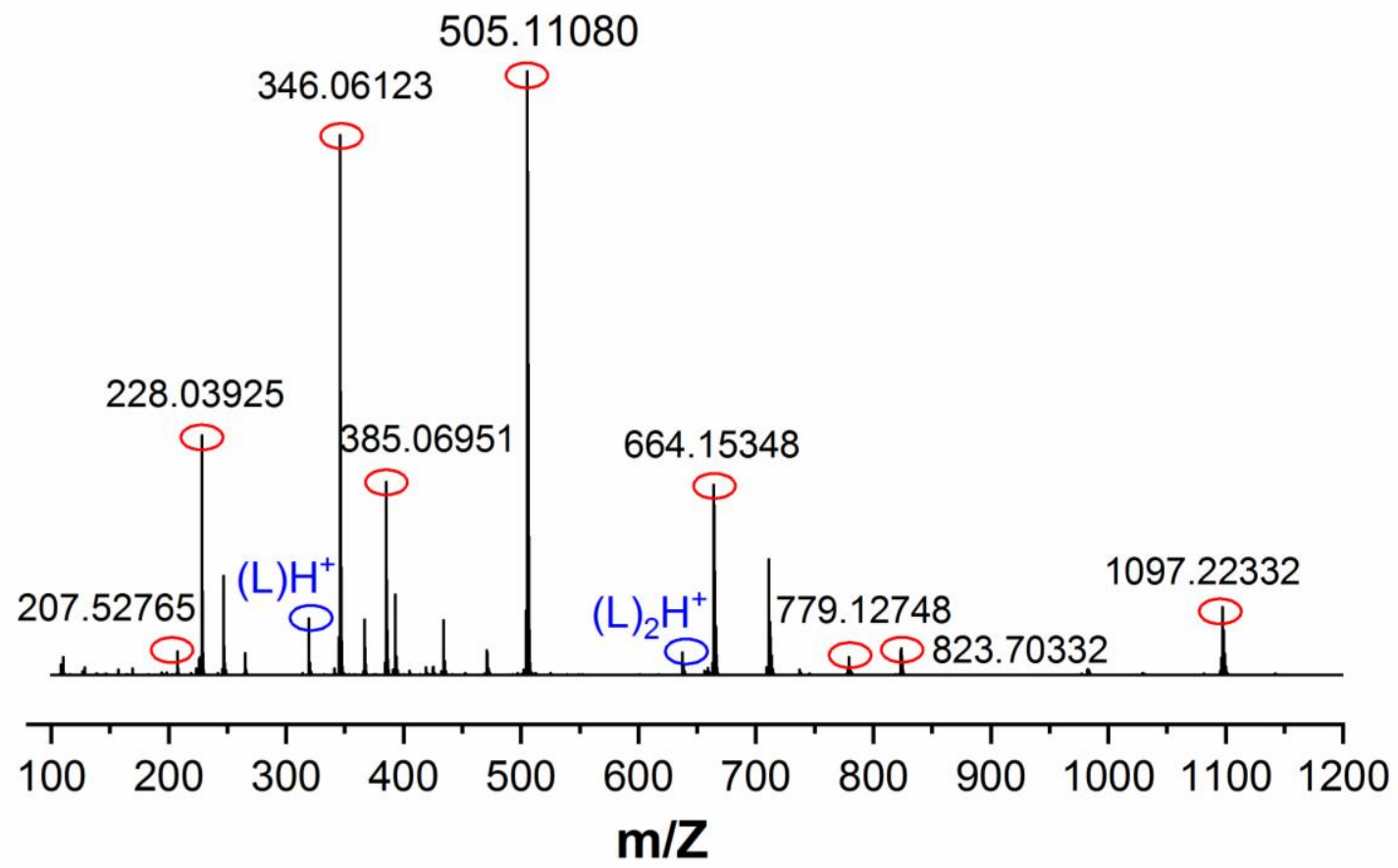

Figure S50. Mass spectrum of $\left[\mathrm{Fe}\left(\mathrm{L}^{4 \mathrm{SIm}}\right)_{3}\right]\left(\mathrm{BF}_{4}\right)_{2}(2)$. Fits of the circled peaks are provided in the following figures.

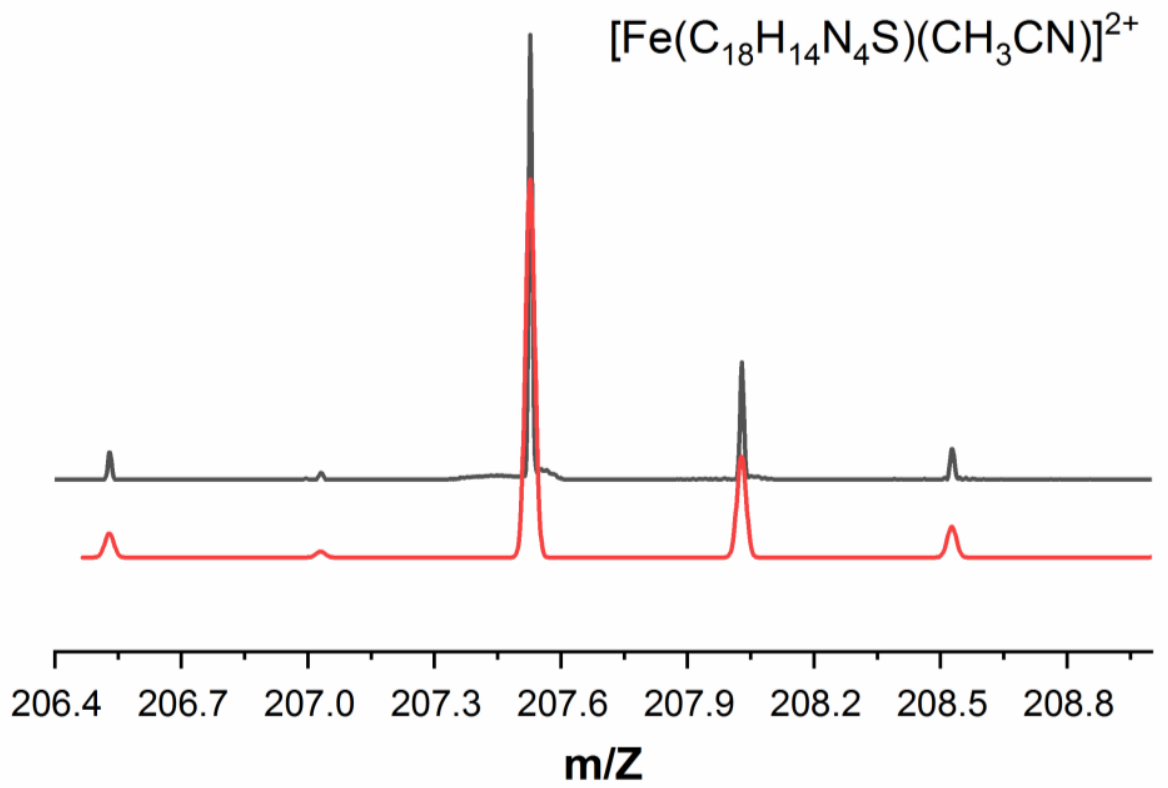

Figure S51. Fit of a peak in the mass spectrum of $\left[\mathrm{Fe}\left(\mathrm{L}^{4 \mathrm{SIm}}\right)_{3}\right]\left(\mathrm{BF}_{4}\right)_{2}(2)$ (Figure $\left.\mathrm{S} 50\right)$ : $\left[\mathrm{Fe}\left(\mathrm{L}^{4 \mathrm{SIm}}\right)\left(\mathrm{CH}_{3} \mathrm{CN}\right)\right]^{2+}$ experimental (black) and simulated pattern (red). 


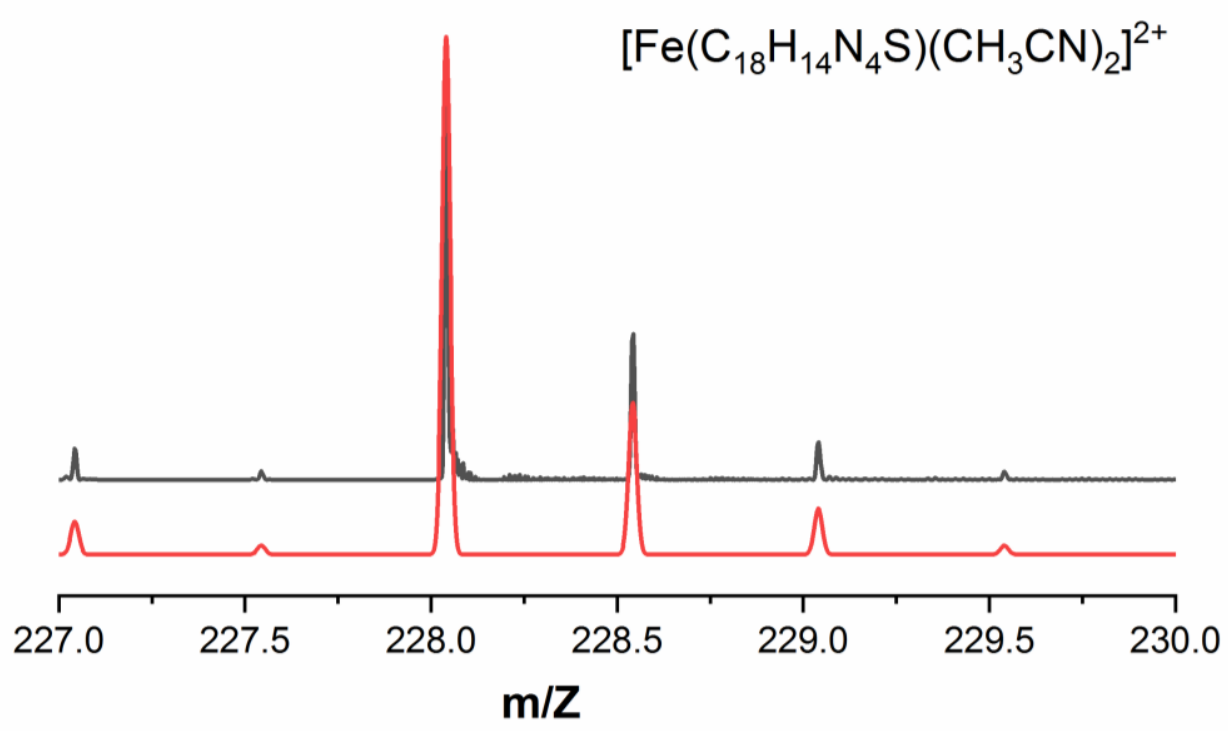

Figure S52. Fit of a peak in the mass spectrum of $\left[\mathrm{Fe}\left(\mathrm{L}^{4 \mathrm{SIm}}\right)_{3}\right]\left(\mathrm{BF}_{4}\right)_{2}(2)$ (Figure S50): $\left[\mathrm{Fe}\left(\mathrm{L}^{4 \mathrm{SIm}}\right)\left(\mathrm{CH}_{3} \mathrm{CN}\right)_{2}\right]^{2+}$ experimental (black) and simulated pattern (red).

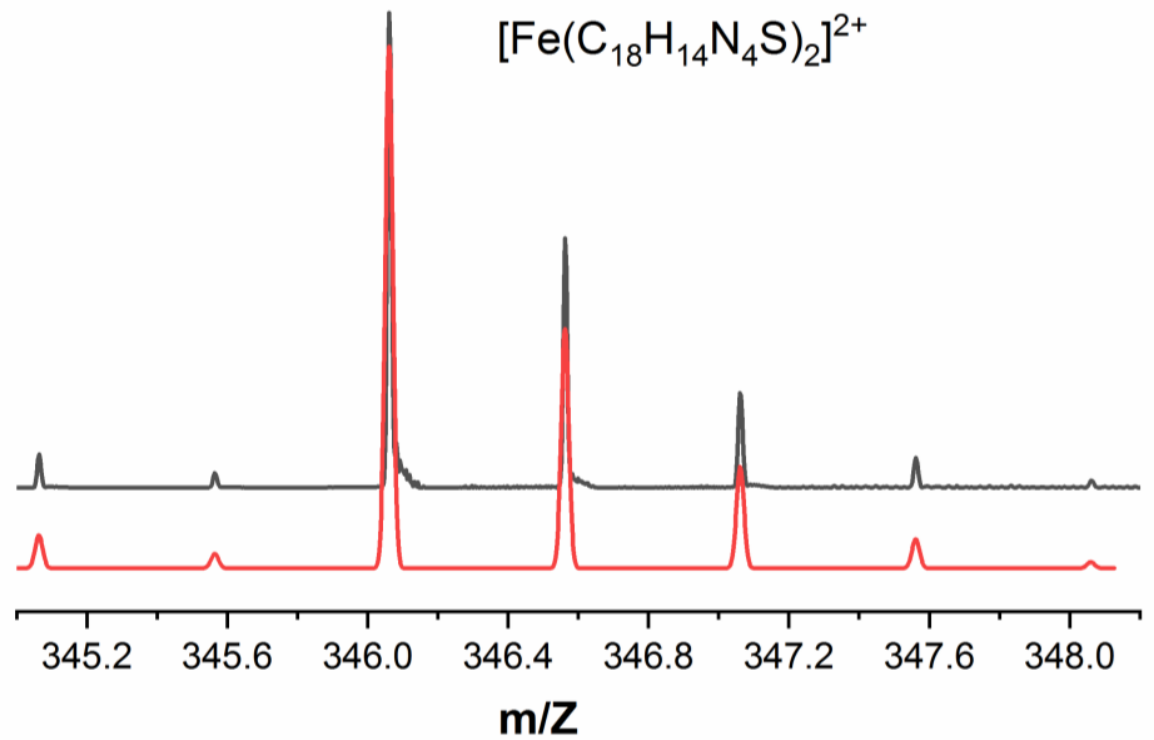

Figure S53. Fit of a peak in the mass spectrum of $\left[\mathrm{Fe}\left(\mathrm{L}^{4 S I m}\right)_{3}\right]\left(\mathrm{BF}_{4}\right)_{2}(2)$ (Figure $\left.\mathrm{S} 50\right)$ : $\left[\mathrm{Fe}\left(\mathrm{L}^{4 S \mathrm{Im}}\right)_{2}\right]^{2+}$ experimental (black) and simulated pattern (red). 


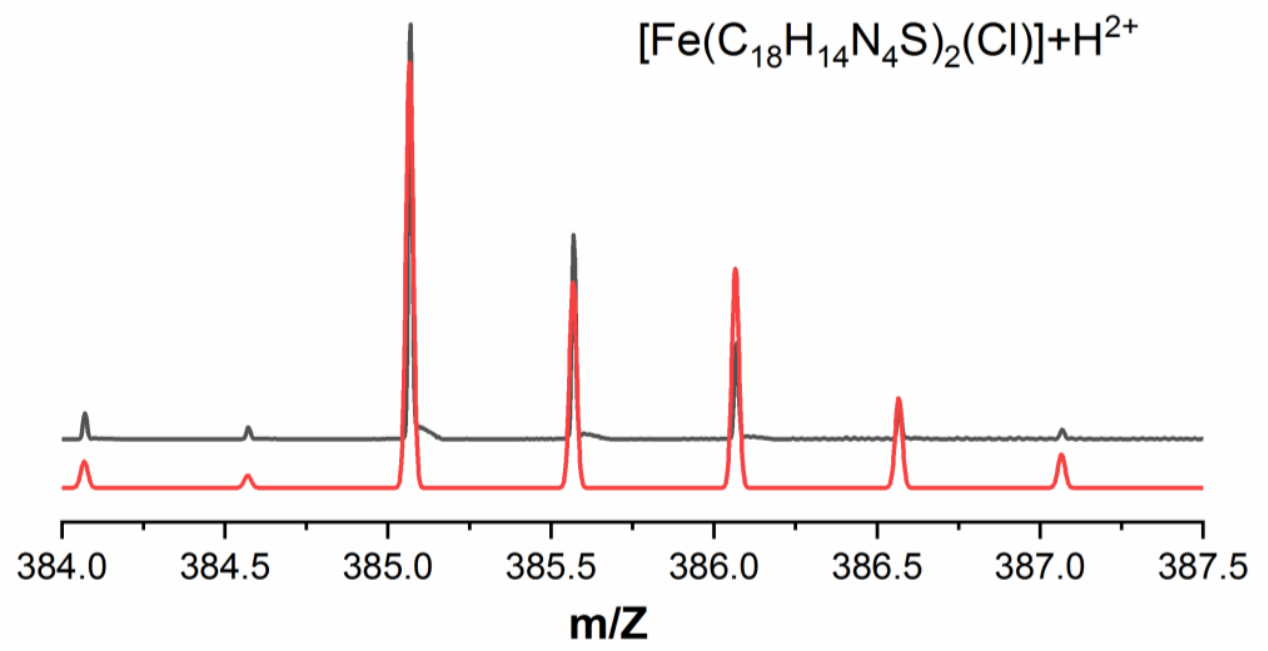

Figure S54. Fit of a peak in the mass spectrum of $\left[\mathrm{Fe}\left(\mathrm{L}^{4 \mathrm{SIm}}\right)_{3}\right]\left(\mathrm{BF}_{4}\right)_{2}(2)\left(\right.$ Figure S50): $\left[\mathrm{Fe}\left(\mathrm{L}^{4 \mathrm{SIm}}\right)_{2}(\mathrm{Cl})\right]+\mathrm{H}^{2+}$ experimental (black) and simulated pattern (red).

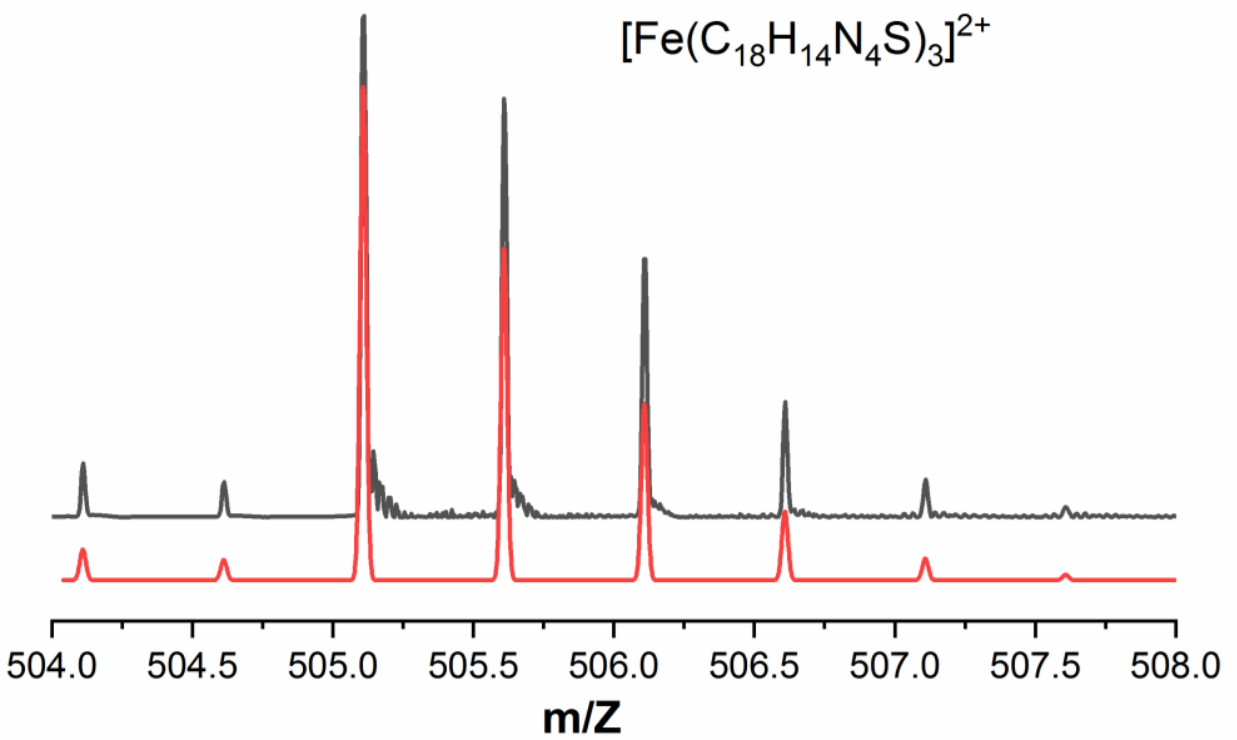

Figure S55. Fit of a peak in the mass spectrum of $\left[\mathrm{Fe}\left(\mathrm{L}^{4 S I m}\right)_{3}\right]\left(\mathrm{BF}_{4}\right)_{2}(2)$ (Figure S50): $\left[\mathrm{Fe}\left(\mathrm{L}^{4 \mathrm{SIm}}\right)_{3}\right]^{2+}$ experimental (black) and simulated pattern (red). 


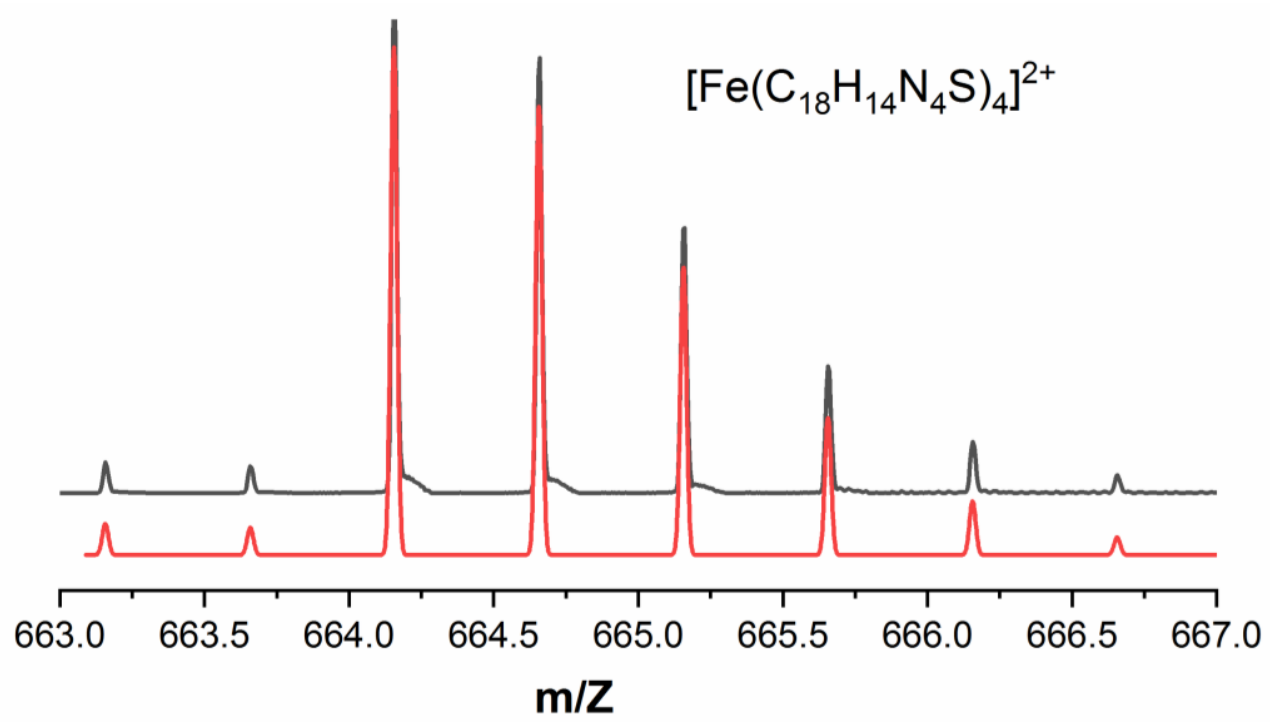

Figure S56. Fit of a peak in the mass spectrum of $\left[\mathrm{Fe}\left(\mathrm{L}^{4 S I m}\right)_{3}\right]\left(\mathrm{BF}_{4}\right)_{2}(2)($ Figure $\mathrm{S} 50)$ : $\left[\mathrm{Fe}\left(\mathrm{L}^{4 \mathrm{SIm}}\right)_{4}\right]^{2+}$ experimental (black) and simulated pattern (red).

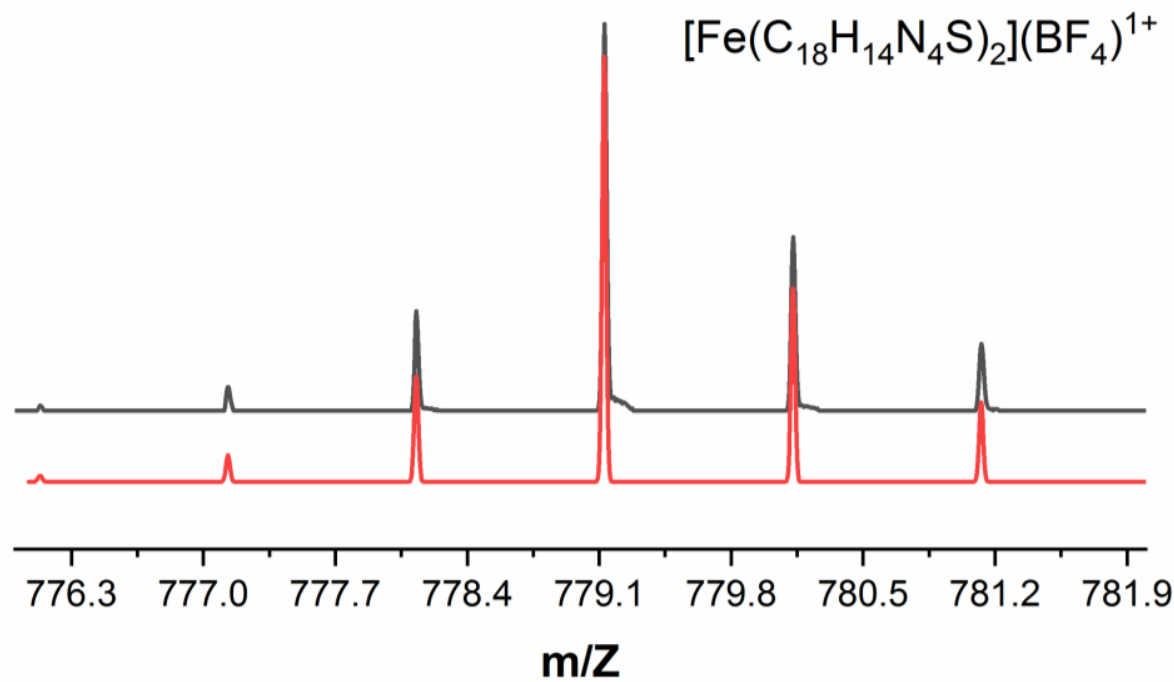

Figure S57. Fit of a peak in the mass spectrum of $\left[\mathrm{Fe}\left(\mathrm{L}^{4 \mathrm{SIm}}\right)_{3}\right]\left(\mathrm{BF}_{4}\right)_{2}(2)$ (Figure S50): $\left[\mathrm{Fe}\left(\mathrm{L}^{4 \mathrm{SIm}}\right)_{2}\right]\left(\mathrm{BF}_{4}\right)^{1+}$ experimental (black) and simulated pattern (red). 


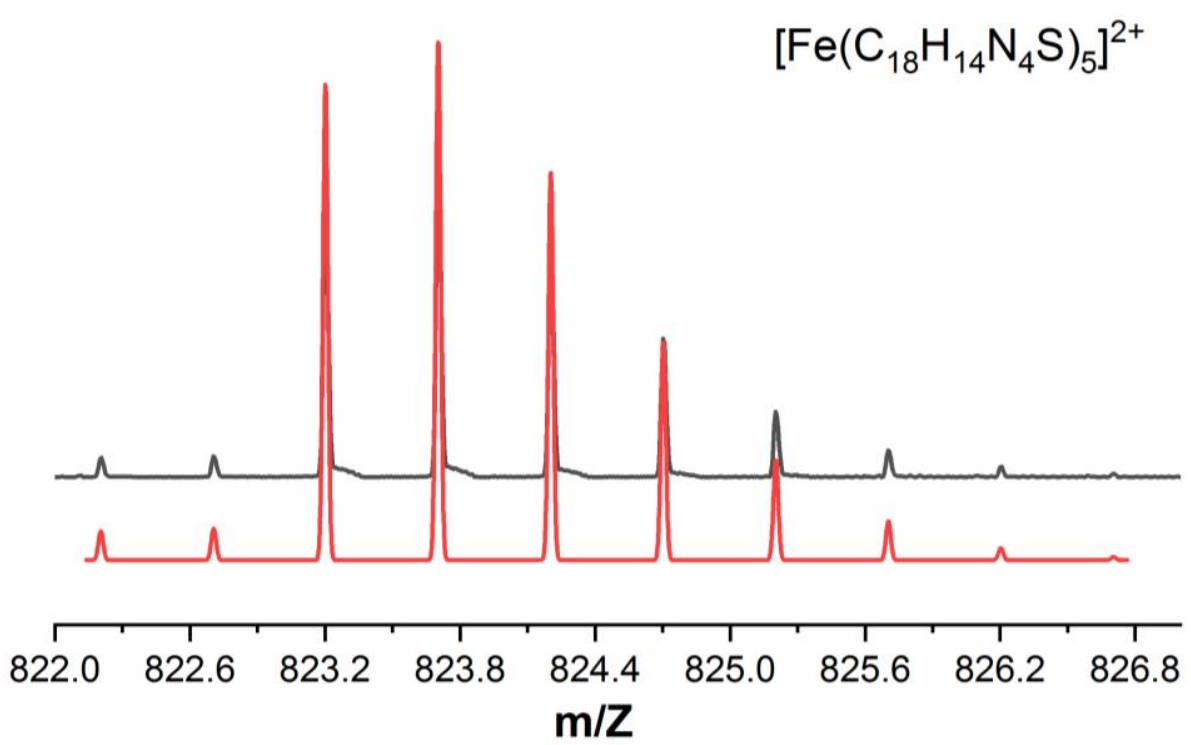

Figure S58. Fit of a peak in the mass spectrum of $\left[\mathrm{Fe}\left(\mathrm{L}^{4 \mathrm{SIm}}\right)_{3}\right]\left(\mathrm{BF}_{4}\right)_{2}(\mathbf{2})$ (Figure S50): $\left[\mathrm{Fe}\left(\mathrm{L}^{4 \mathrm{SIm}}\right)_{5}\right]^{2+}$ experimental (black) and simulated pattern (red).

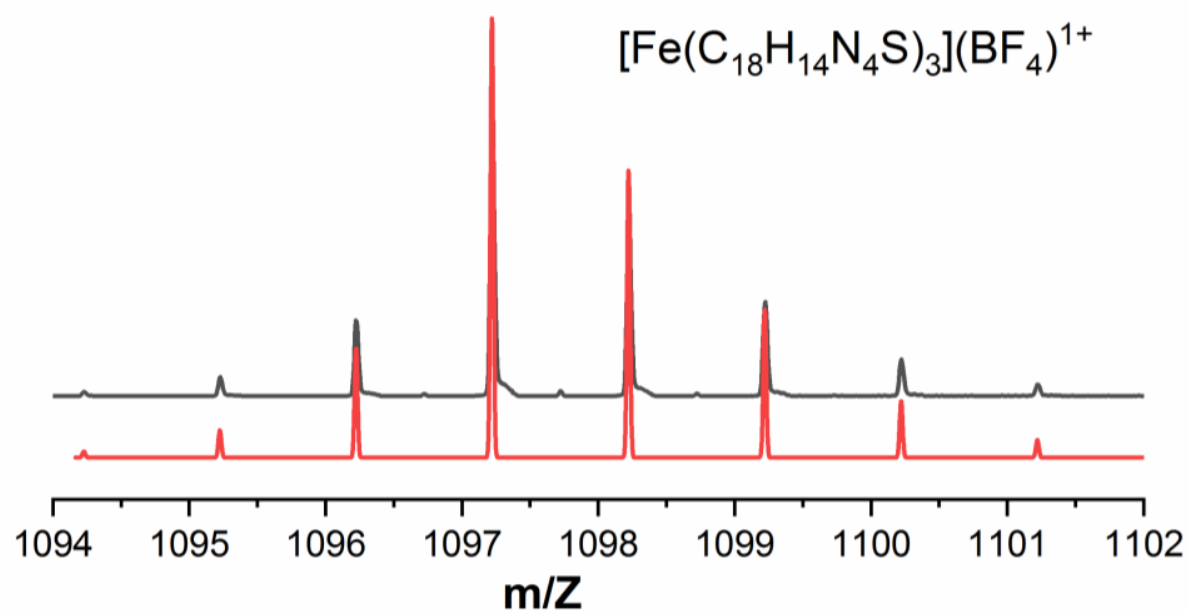

Figure S59. Fit of a peak in the mass spectrum of $\left[\mathrm{Fe}\left(\mathrm{L}^{4 S \mathrm{Im}}\right)_{3}\right]\left(\mathrm{BF}_{4}\right)_{2}(2)$ (Figure S50): $\left[\mathrm{Fe}\left(\mathrm{L}^{4 \mathrm{SIm}}\right)_{3}\right]\left(\mathrm{BF}_{4}\right)^{1+}$ experimental (black) and simulated pattern (red). 


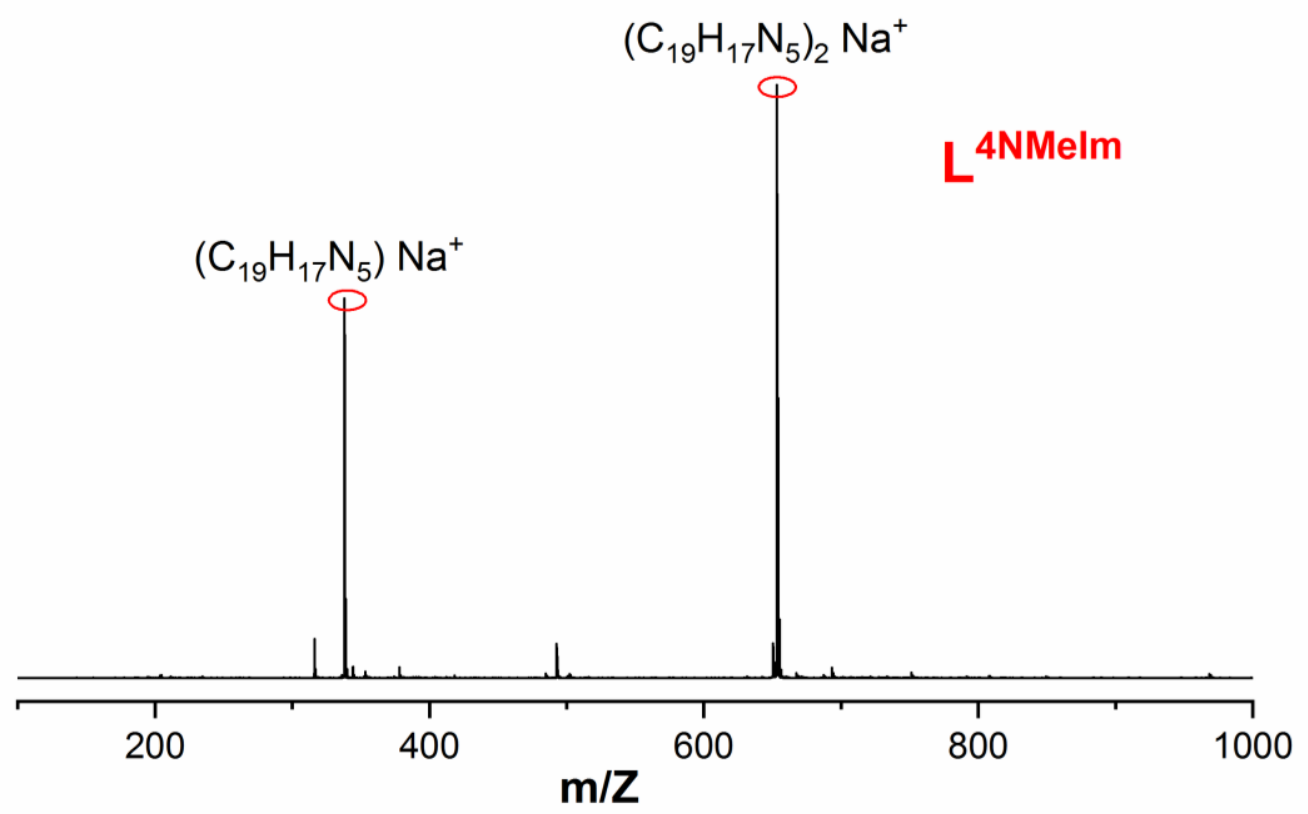

Figure S60. Mass spectrum of $\mathbf{L}^{4 \mathrm{NMelm}}$.

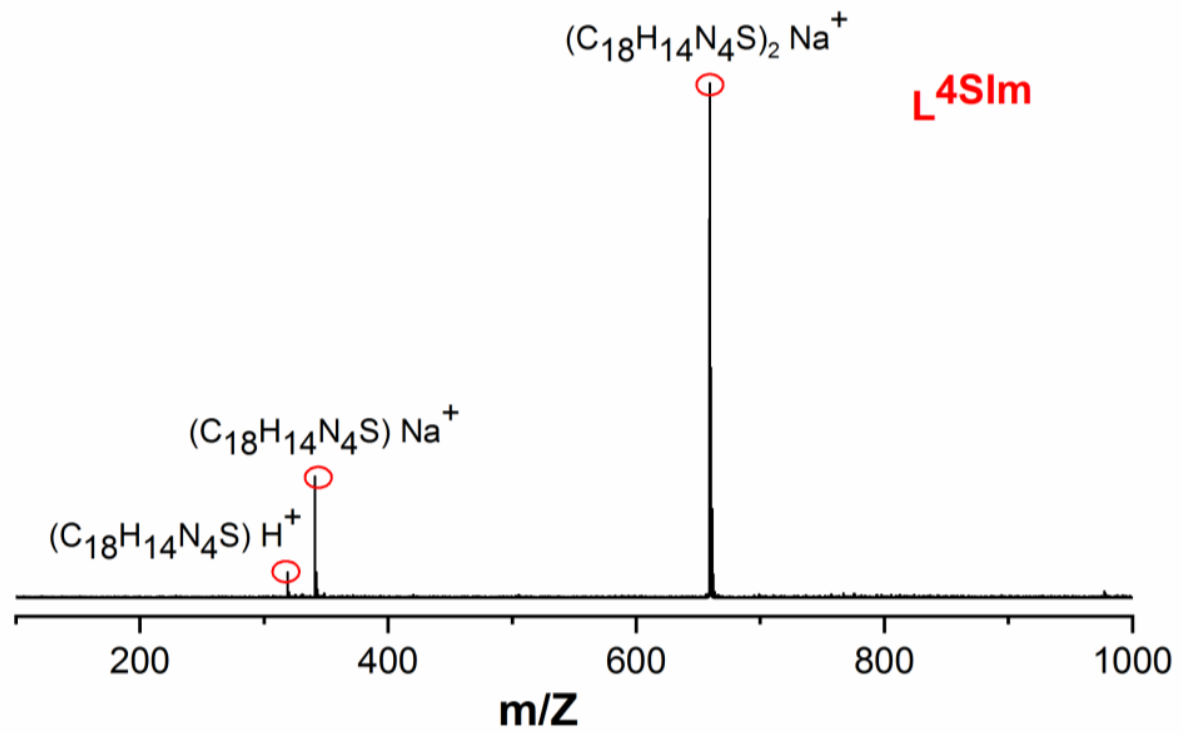

Figure S61. Mass spectrum of $\mathrm{L}^{4 \mathrm{SIm}}$. 
NMR spectra
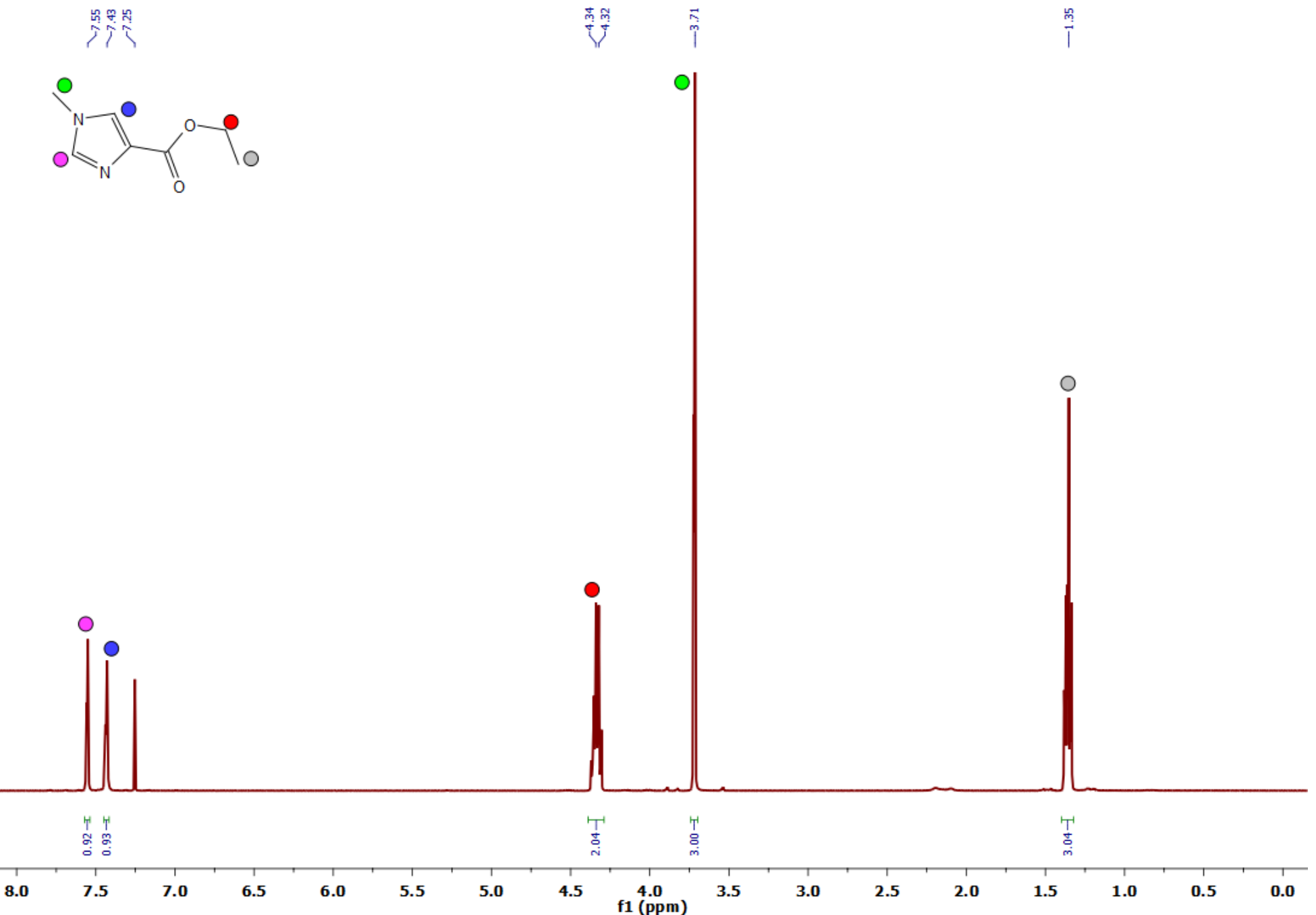

Figure $\mathrm{S} 62 .{ }^{1} \mathrm{H}$ NMR spectrum (400 MHz) of ethyl 1-methyl-1H-imidazole-4-carboxylate in $\mathrm{CDCl}_{3}$. 

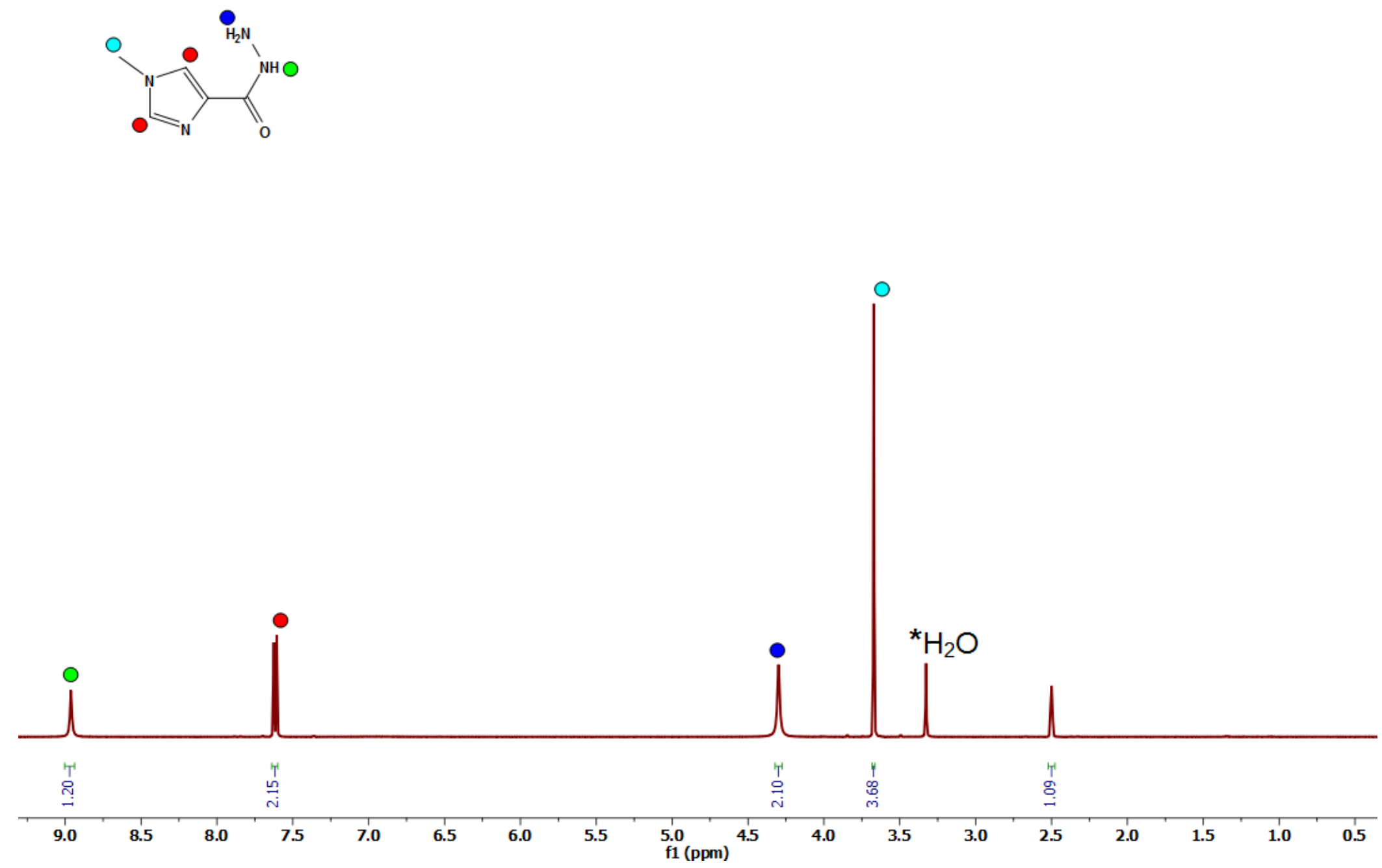

Figure S63. ${ }^{1} \mathrm{H}$ NMR spectrum $(400 \mathrm{MHz}$ ) of 1-methyl-1H-imidazole-4-carbohydrazide in DMSO-d 6 . 


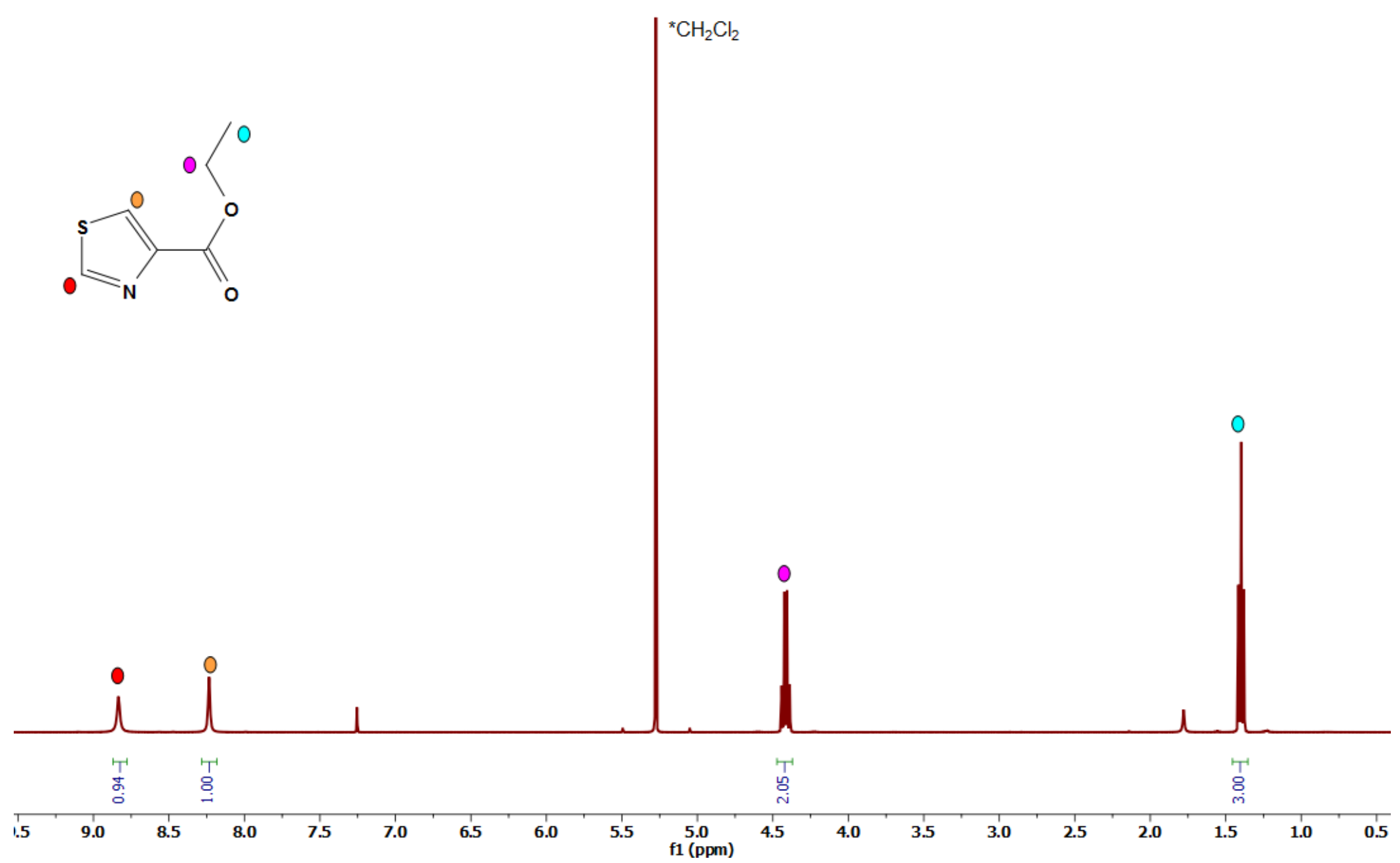

Figure $564 .{ }^{1} \mathrm{H}$ NMR spectrum $\left(400 \mathrm{MHz}\right.$ ) of ethyl thiazole-4-carboxylate in $\mathrm{CDCl}_{3}$. 


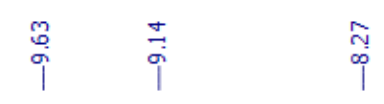

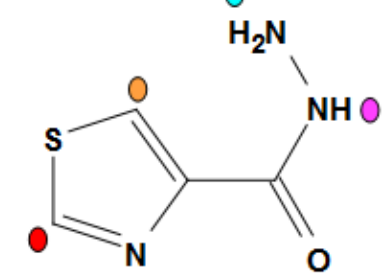

${ }^{*} \mathrm{H}_{2} \mathrm{O}$

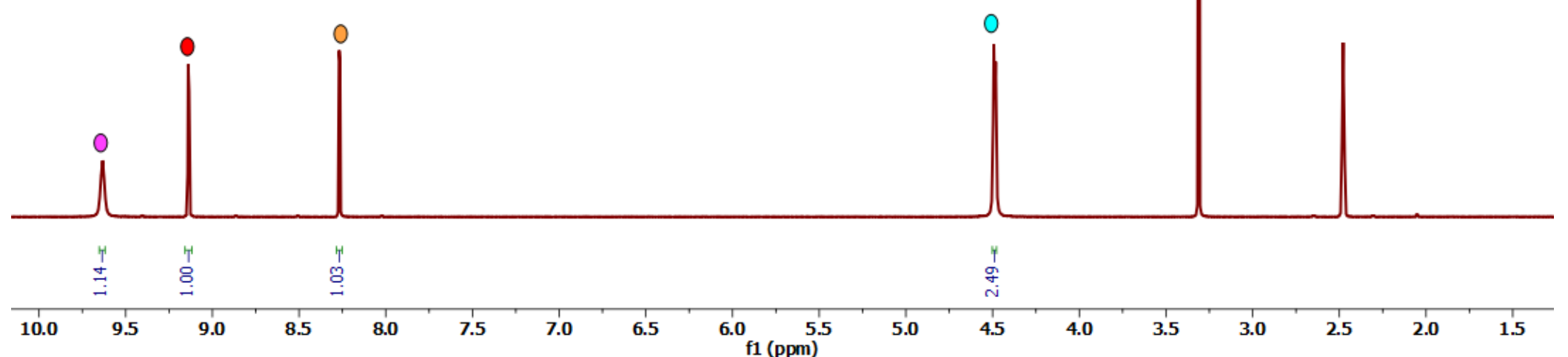

Figure $\mathrm{S} 65 .{ }^{1} \mathrm{H}$ NMR spectrum $(400 \mathrm{MHz})$ of thiazole-4-carbohydrazide in DMSO-d $\mathrm{d}_{6}$. 


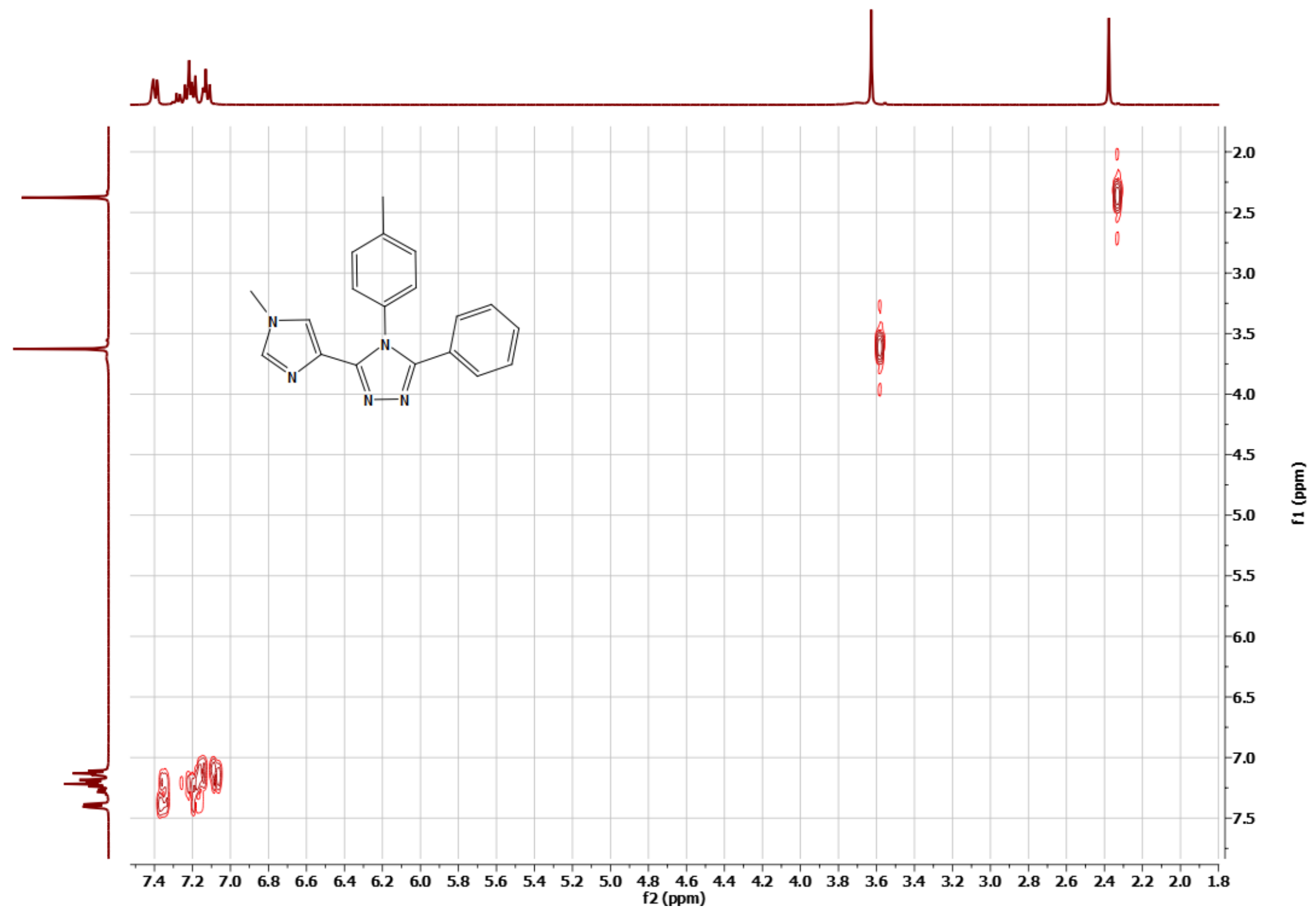

Figure S66. gCOSY NMR spectrum (400 MHz) of $\mathrm{L}^{4 \mathrm{NMelm}}$ in $\mathrm{CDCl}_{3}$ at $298 \mathrm{~K}$. 


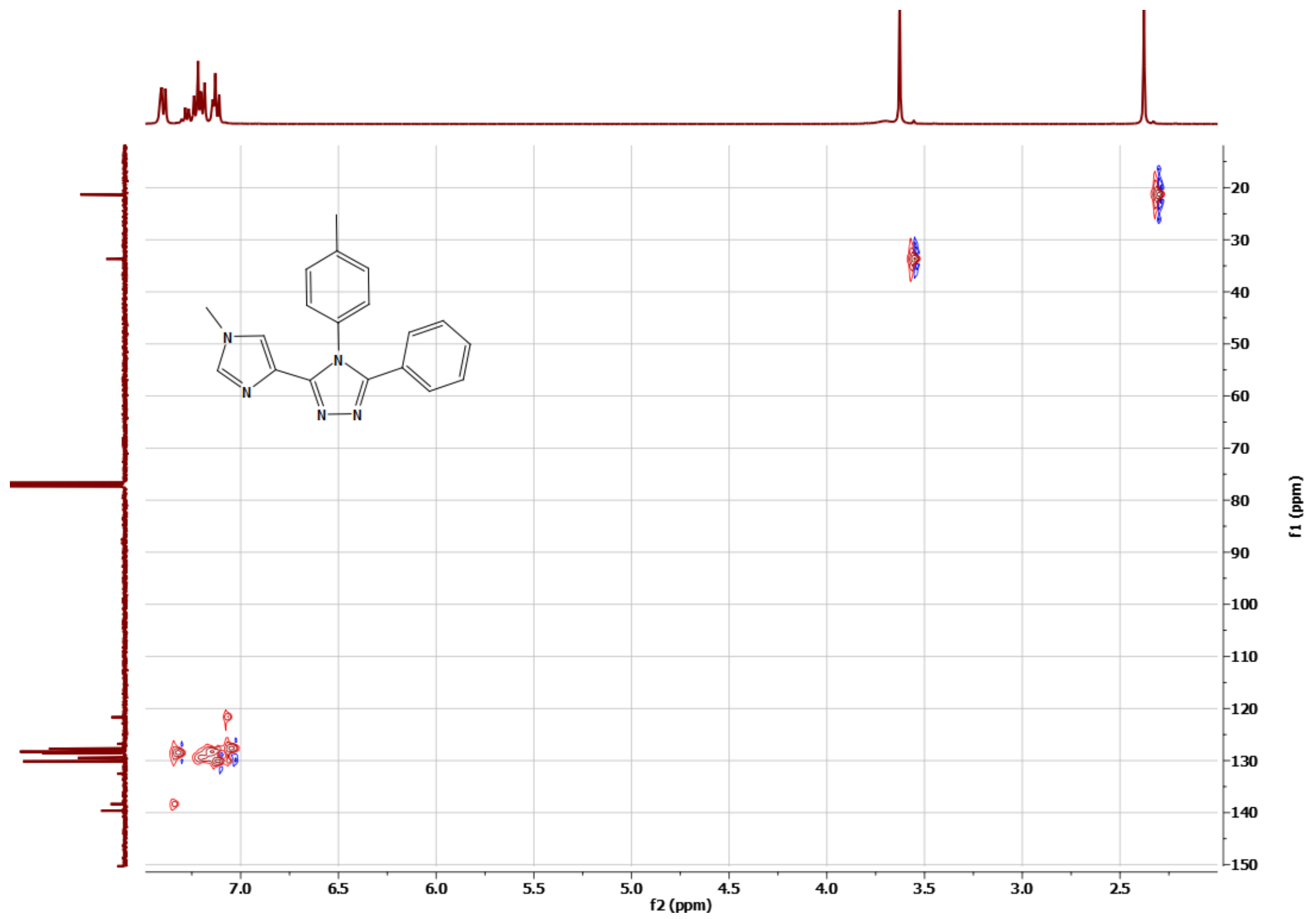

Figure S67. HSQCAD NMR spectrum (400 MHz) of $\mathrm{L}^{4 \mathrm{NMelm}}$ in $\mathrm{CDCl}_{3}$ at $298 \mathrm{~K}$. 

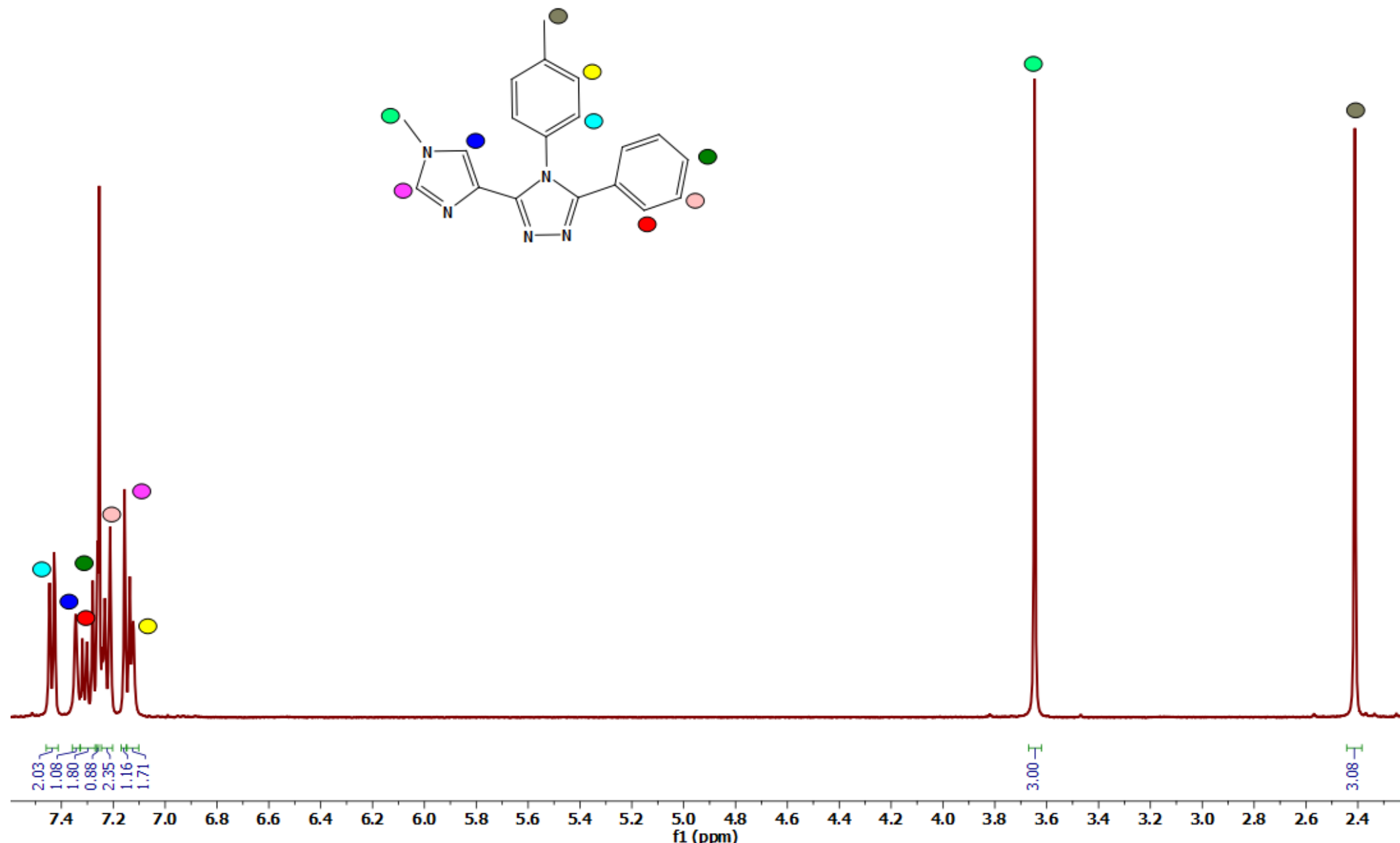

Figure S68. ${ }^{1} \mathrm{H}$ NMR spectrum $(400 \mathrm{MHz})$ of $\mathrm{L}^{4 \mathrm{NMelm}}$ in $\mathrm{CDCl}_{3}$ at $298 \mathrm{~K}$. 


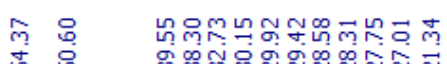

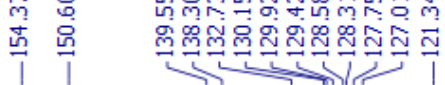
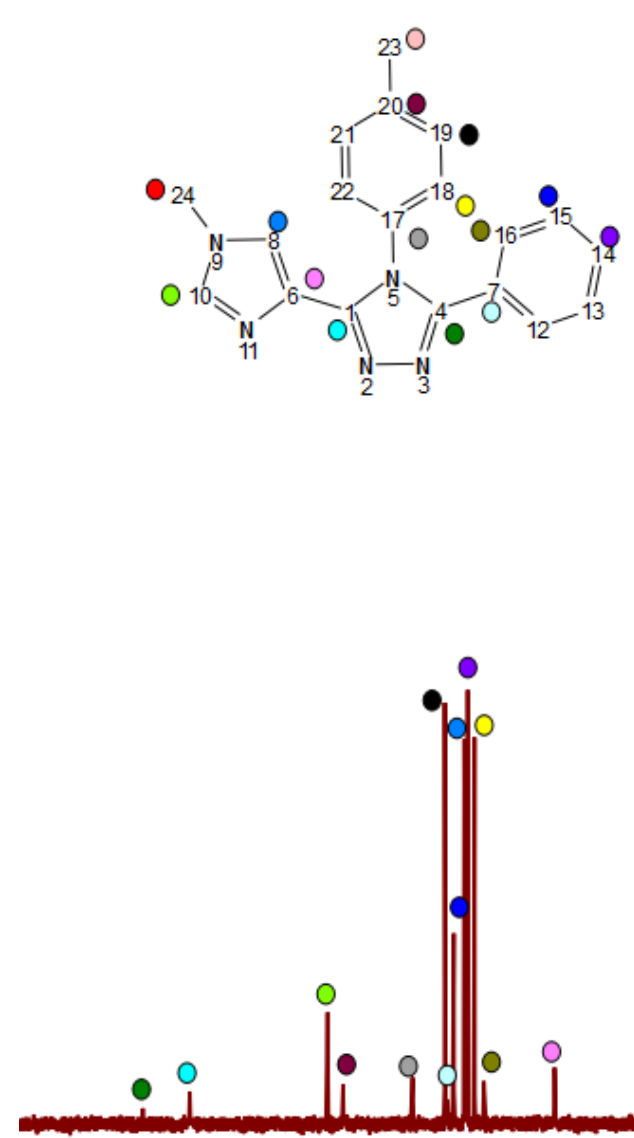

160

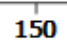

140

130

120

110

100

90

f1 (ppm)

70

60

50

40

30

20

Figure S69. ${ }^{13} \mathrm{C}$ NMR spectrum $(100 \mathrm{MHz})$ of $\mathrm{L}^{4 \mathrm{NMelm}}$ in $\mathrm{CDCl}_{3}$ at $298 \mathrm{~K}$ 


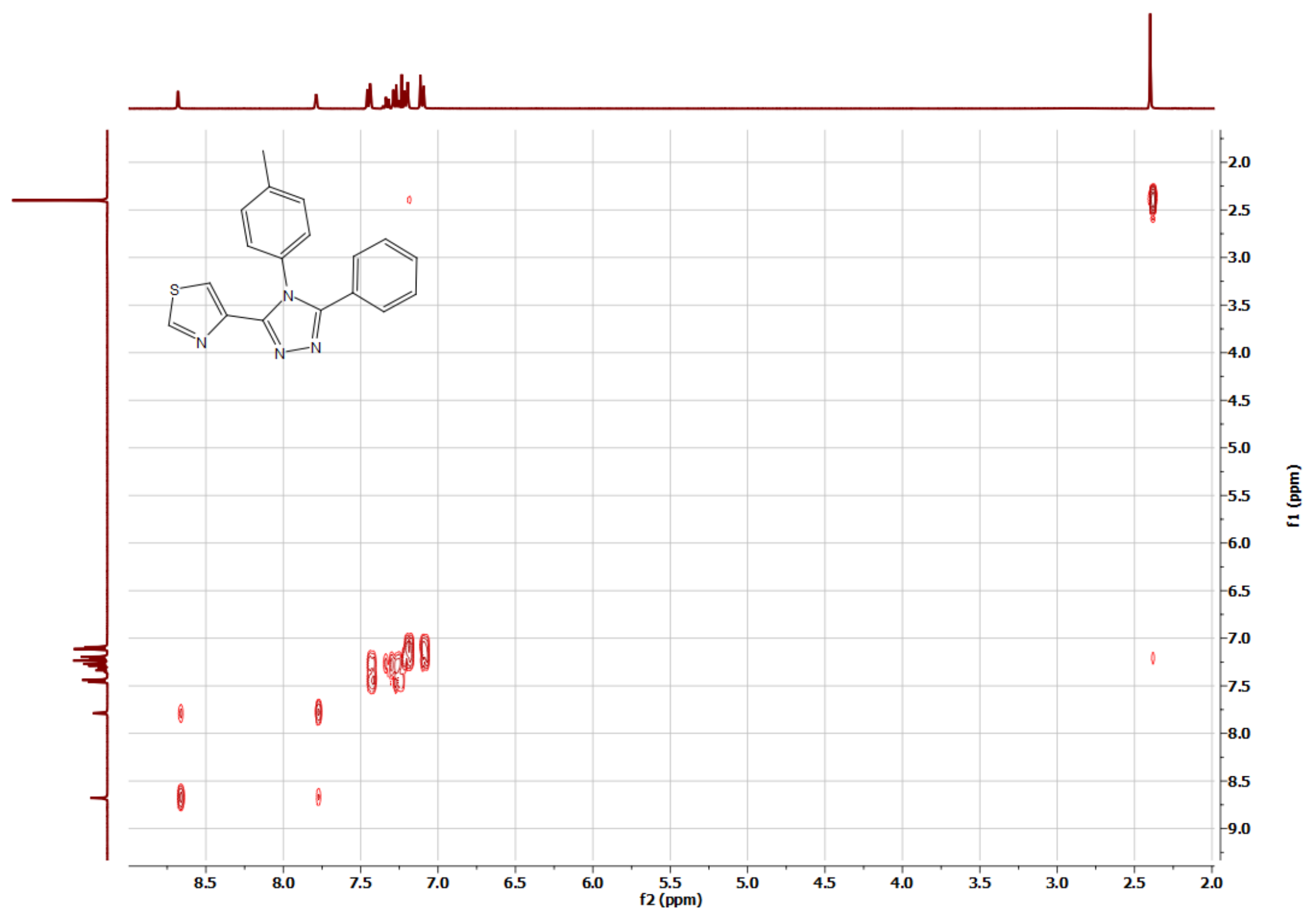

Figure S70. gCOSY NMR spectrum (400 MHz) of $\mathrm{L}^{45 \mathrm{~m}}$ in $\mathrm{CDCl}_{3}$ at $298 \mathrm{~K}$. 


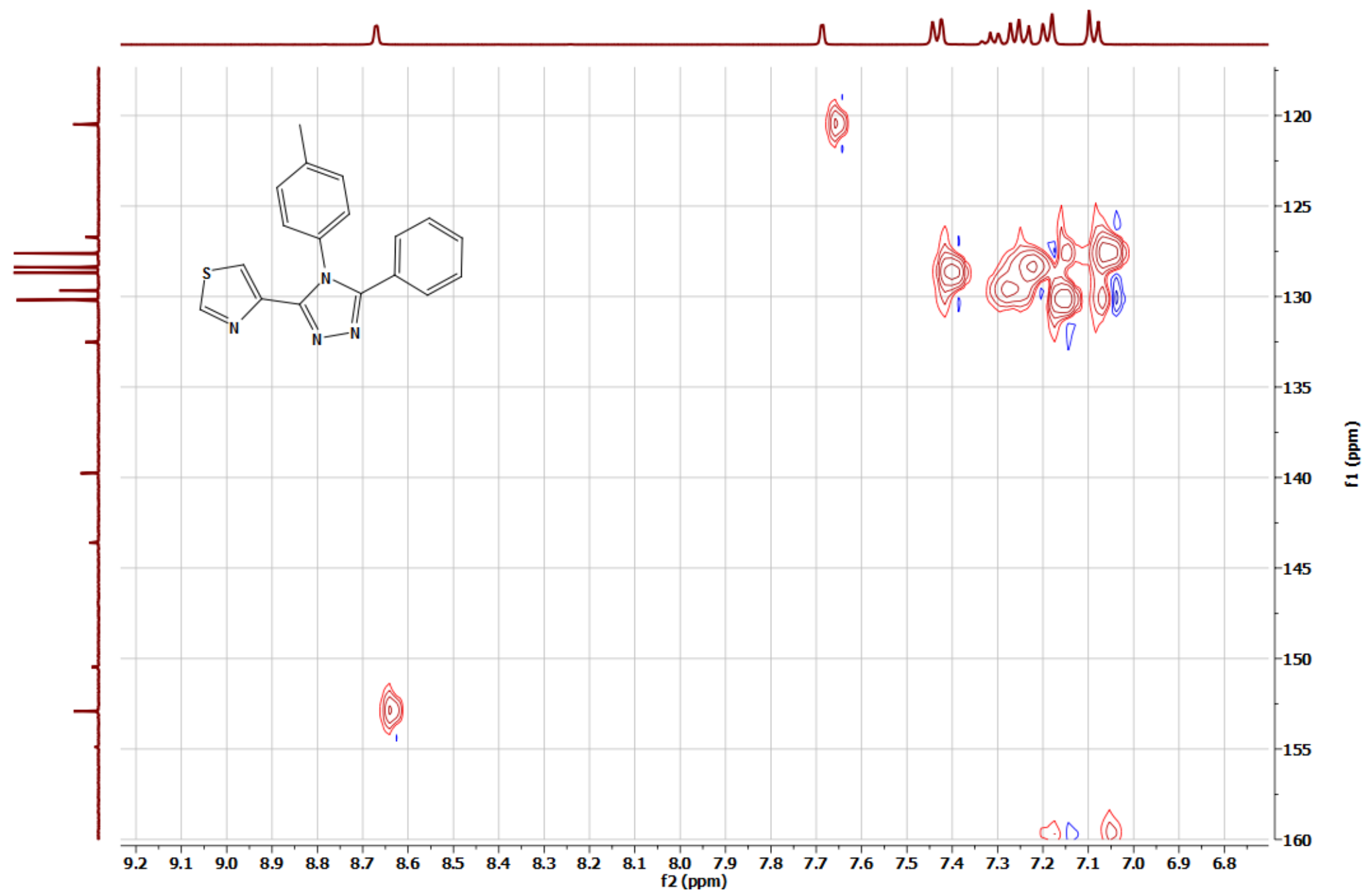

Figure S71. HSQCAD NMR spectrum (400 MHz) of $\mathrm{L}^{45 \mathrm{Im}}$ in $\mathrm{CDCl}_{3}$ at $298 \mathrm{~K}$. 

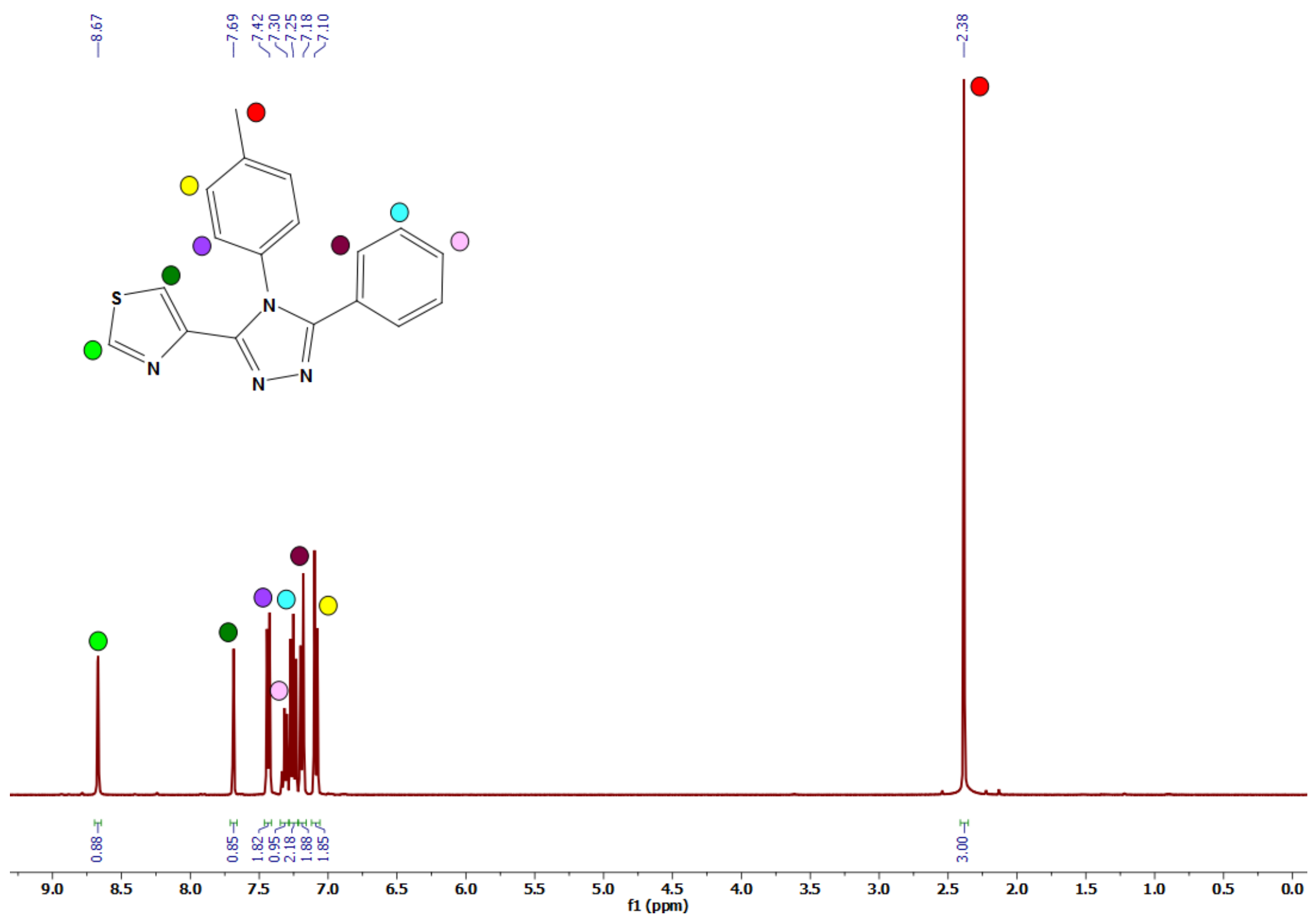

Figure S72. ${ }^{1} \mathrm{H}$ NMR spectrum (400 MHz) of $\mathrm{L}^{45 \mathrm{Im}}$ in $\mathrm{CDCl}_{3}$ at $298 \mathrm{~K}$. 


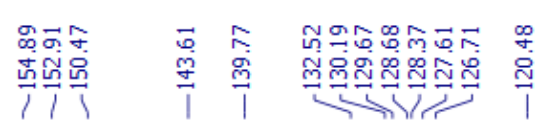
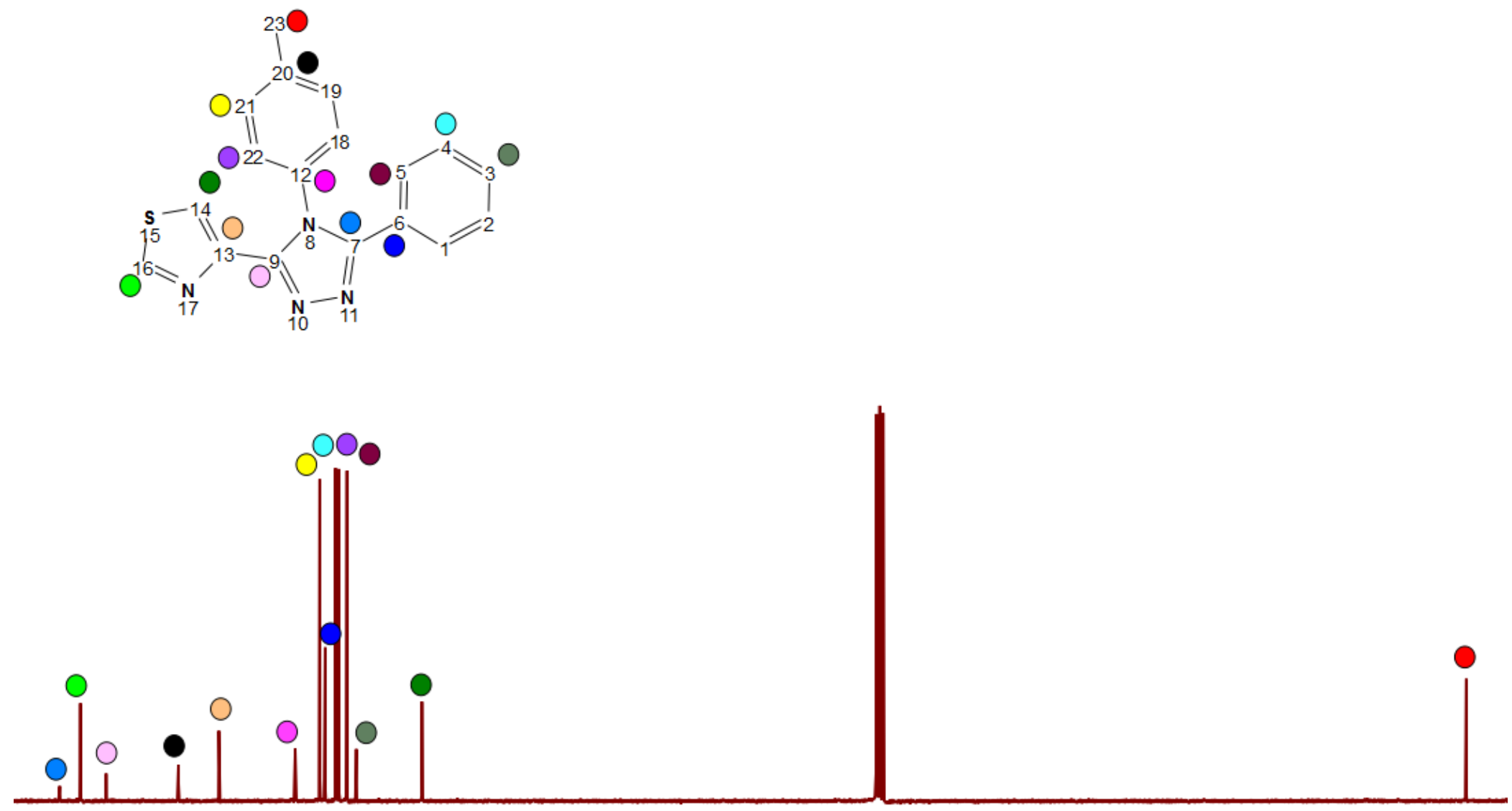

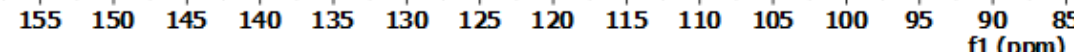

$8075 \quad 70 \quad 65$

Figure S73. ${ }^{13} \mathrm{C}$ NMR spectrum $(100 \mathrm{MHz})$ of $\mathrm{L}^{4 \mathrm{SIm}}$ in $\mathrm{CDCl}_{3}$ at $298 \mathrm{~K}$. 


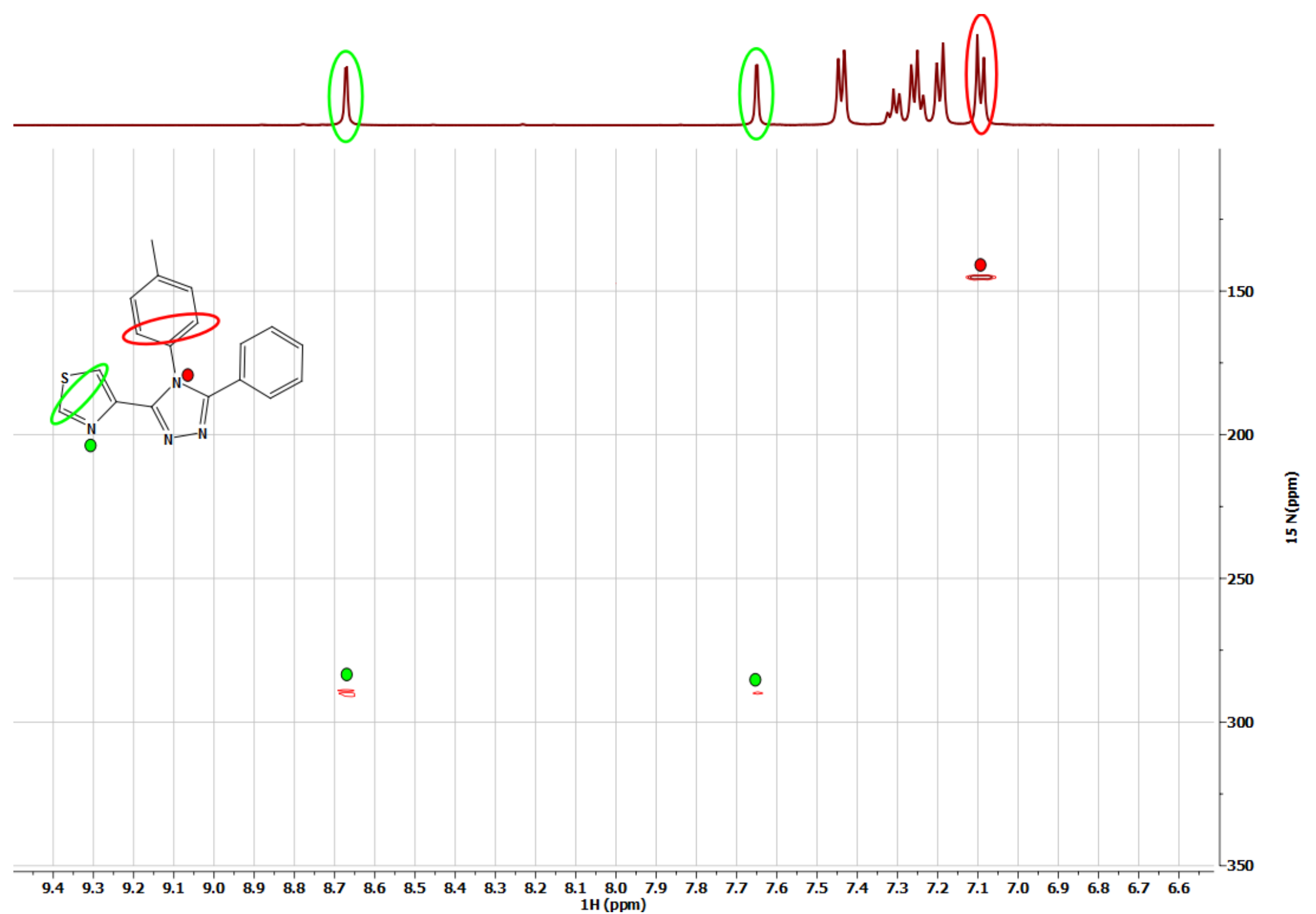

Figure $\mathrm{S} 74 .{ }^{15} \mathrm{~N}$ (indirect method) NMR spectrum $(500 \mathrm{MHz})$ of $\mathrm{L}^{45 \mathrm{Im}}$ in $\mathrm{CDCl}_{3}$ at $298 \mathrm{~K}$. 


\section{References}

(1) Shores, M. P.; Klug, C. M.; Fiedler, S. R., Spin-state switching in solution. In Spin-Crossover Materials: Properties and Applications, John Wiley \& Sons Ltd: Chichester, 2013; pp 281-301.

(2) Kershaw Cook, L. J.; Kulmaczewski, R.; Mohammed, R.; Dudley, S.; Barrett, S. A.; Little, M. A.; Deeth, R. J.; Halcrow, M. A., A unified treatment of the relationship between ligand substituents and spin state in a family of iron(II) complexes. Angew. Chem. Int. Ed., 2016, 55, 4327-4331.

(3) Rodríguez-Jiménez, S.; Brooker, S., Solid Versus Solution Spin Crossover and the Importance of $\mathrm{Fe}-\mathrm{N} \equiv \mathrm{C}(\mathrm{X})$ Angle. Inorg. Chem., 2017, 56, 13697-13708.

(4) Kahn, O., Molecular Magnetism. VCH Publishers Inc.: New York, 1993.

(5) Ahuja, S., Chromatography and Separation Science. Academic Press: 2003; Vol. 4.

(6) Schirmer, R. E., Modern Methods of Pharmaceutical Analysis, Second Edition. Taylor \& Francis: 1990.

(7) Reichardt, C., Chem. Rev., 1994, 94, 2319.

(8) Marcus, Y., The properties of organic liquids that are relevant to their use as solvating solvents. Chemical Society Reviews, 1993, 22, 409-416.

(9) Swain, C. G.; Swain, M. S.; Powell, A. L.; Alunni, S., Solvent effects on chemical reactivity. Evaluation of anion- and cation-solvation components. J. Am. Chem. Soc., 1983, 105, 502-513.

(10) Barton, A. F. M., Solubility parameters. Chem. Rev., 1975, 75, 731-753.

(11) Spingler, B.; Schnidrig, S.; Todorova, T.; Wild, F., Some thoughts about the single crystal growth of small molecules. CrystEngComm, 2012, 14, 751-757.

(12) Kamlet, M. J.; Abboud, J. L. M.; Abraham, M. H.; Taft, R. W., Linear solvation energy relationships. 23. A comprehensive collection of the solvatochromic parameters, $p^{*}, a$, and $b$, and some methods for simplifying the generalized solvatochromic equation. J. Org. Chem., $1983,48,2877-2887$.

(13) Catalán, J.; Díaz, C.; López, V.; Pérez, P.; De Paz, J.-L. G.; Rodríguez, J. G., A generalized solvent basicity scale: The solvatochromism of 5-nitroindoline and its homomorph 1-methyl-5nitroindoline. Liebigs Ann. Chem., 1996, 1996, 1785-1794.

(14) Gutmann, V., The Donor-Acceptor Approach to Molecular Interaction. Plenum Press: New York, 1978.

(15) Gutmann, V.; Wychera, E., Coordination reactions in non aqueous solutions - The role of the donor strength. Inorg. Nucl. Chem. Lett., 1966, 2, 257-260.

(16) Turner, J. W.; Schultz, F. A., Solution characterization of the iron(II) bis(1,4,7triazacyclononane) spin-equilibrium reaction. Inorganic Chemistry, 2001, 40, 5296-5298.

(17) Hogue, R. W.; Feltham, H. L. C.; Miller, R. G.; Brooker, S., Spin crossover in dinuclear $\mathrm{N}_{4} \mathrm{~S}_{2}$ iron(II) thioether-triazole complexes: access to [HS-HS], [HS-LS] and [LS-LS] states. Inorg. Chem., 2016, 55, 4152-4165. 